\title{
Discovery, optimization, and cellular activities of 2- (aroylamino)cinnamamide derivatives against colon cancer
}

\author{
Abdelsattar M. Omar ${ }^{1,2}$, Moustafa E. El-Araby ${ }^{1 *}$ Tamer M. Abdelghany $^{3}$, Martin K. \\ $\mathrm{Safo}^{4}$, Mostafa H. Ahmed ${ }^{4}$, Rio Boothello ${ }^{5,6}$, Bhaumik B Patel ${ }^{5,6}$, Mohamed S. Abdel- \\ Bakky $^{4}$, Azizah M. Malebari ${ }^{1}$, Radwan S. Elhaggar ${ }^{7}$
}

\footnotetext{
${ }^{1}$ Department of Pharmaceutical Chemistry, Faculty of Pharmacy, King Abdulaziz University, Jeddah 21589, Saudi Arabia

${ }^{2}$ Department of Pharmaceutical Chemistry, Faculty of Pharmacy, Al-Azhar University, Cairo 11884, Egypt

${ }^{3}$ Department of Pharmacology, Faculty of Pharmacy, Al-Azhar University, Cairo 11884, Egypt

${ }^{4}$ Department of Medicinal Chemistry, and the Institute for Structural Biology, Drug Discovery and Development, School of Pharmacy, Virginia Commonwealth University, Richmond, VA 23298, USA

${ }^{5}$ Division of Hematology and Oncology, Department of Medicine, Virginia Commonwealth University, and Massey Cancer Center, Richmond, VA 23298. USA

${ }^{6}$ Hunter Holmes McGuire VA Medical Center, Richmond, VA 23249, USA

${ }^{7}$ Department of Pharmaceutical Chemistry, Faculty of Pharmacy, Helwan University, Cairo 11790, Egypt

* Correspondence: madaoud@kau.edu.sa
}

\begin{abstract}
Curcumin and trans-cinnamaldehyde are acrolein-based Michael acceptor compounds that are commonly found in domestic condiments, and known to cause cancer cell death via redox mechanisms. Based on the structural features of these compounds we designed and synthesized several 2-cinnamamido-N-substitutedcinnamamide (bis-cinnamamide) compounds. One of the derivatives, $(Z)-2-[(E)$ cinnamamido]-3-phenyl-N-propylacrylamide $\mathbf{1 5 1 2}$ showed a moderate antiproliferative potency (HCT-116 cell line inhibition of $32.0 \mu \mathrm{M}$ ), good selectivity
\end{abstract}


profile (no inhibition of normal cell lines), and proven cellular activities leading to apoptosis. SAR studies led to more than 10-fold increase in activity. Our most promising compound, $\quad[(Z)-3-(1 H$-indol-3-yl)- $N$-propyl-2-[(E)-3-(thien-2yl)propenamido)propenamide] $\mathbf{4 1 1 2}$ killed colon cancer cells at $\mathrm{IC}_{50}=0.89 \mu \mathrm{M}$ (Caco-2), $2.85 \mu \mathrm{M}$ (HCT-116) and 1.65 $\mu \mathrm{M}$ (HT-29), while exhibiting much weaker potency on C-166 and BHK normal cell lines $\left(\mathrm{IC}_{50}=71 \mu \mathrm{M}\right.$ and $77.6 \mu \mathrm{M}$, respectively). Cellular studies towards identifying the compounds mechanism of cytotoxic activities revealed that apoptotic induction occurs in part as a result of oxidative stress. Importantly, the compounds showed inhibition of cancer stem cells that are critical for maintaining the potential for self-renewal and stemness. The results presented here show discovery of covalently-acting Michael addition compounds that potently kill cancer cells by a defined mechanism, with minimal effect on normal noncancerous cell.

Keywords: Michael acceptor; safe covalent drugs; oxidative stress inducers; transcinnamaldehyde; curcumin; colorectal cancer

\section{INTRODUCTION}

Propenamide is a Michael acceptor (MA) moiety that is frequently employed in designing drugs and drug candidates [1-3]. For instance, afatinib (Figure 1) a targetspecific propenamide that selectively inhibits mutated HER2 kinase [4] has been recently approved by the FDA for the treatment of non-small cell lung cancer [5]. Chidamide is a histone acetylase (HDAC) inhibitor approved in China for the treatment of advanced peripheral T-cell lymphoma. Chidamide incorporates 3-(3-pyridyl)acryloyl group which 
can be considered bioisosteric to cinnamyl moiety [6]. Other examples, among many, include ibrutinib (BTK inhibitor) and neratinib (HER-2 inhibitor) developed for B-cell cancers and solid tumors, respectively [7, 8]. The efficacies of these drugs are, at least in part, depend on the MA functionalities. There are anticancer Mechanistically, the MAs cause cancer cell apoptosis by increasing the oxidative stress inside these cells. The cellular prooxidant induction by MAs is attributed to covalently ligation of SH groups of certain targets involved in regeneration of reduced glutathione (GSH). This result in accumulation of reactive oxygen species (ROS) which cause cancer cell cycle exits and apoptosis [9].<smiles>C=CC=CCCCCCCCCCCCCCC(=O)CC(=O)C=Cc1ccc(O)c(OC)c1</smiles>

Figure 1. Drugs and naturally occurring compounds containing Michael Addition moiety.

Acrolein (propenal, Figure 1) is the simplest enone MA characterized by high reactivity and non-selectivity to cellular nucleophiles and, therefore, is considered as a toxic environmental pollutant with well-known carcinogenic activities [10]. Interestingly, acrolein has also been reported to inhibit cancer cell growth. This is mediated by inhibition of the $\beta$-subunit of $\mathrm{NF} \kappa \mathrm{B}$, an anti-apoptotic protein, via covalent binding with the 
nucleophilic Cys-61 and Arg-307 [11]. Replacement of the aldehyde group of acrolein with amide group (acrylamide moiety) is known to attenuate the reactivity of the MA moiety leading to less toxic derivatives [12]. In another direction, simple modification of acrolein by adding a phenyl group to the $\beta$-carbon provides a moiety that is found in natural products such as trans-Cinnamaldehyde (tCA) and curcumin (Figure 1). These domestic condiments are highly safe natural condiments with confirmed antiproliferative activities against several cancer cell lines $[9,13,14]$. Driven by the lead pharmacophores presence in natural food, attractive anticancer activities, and well-known safety profiles [9, 15-20], we envisaged tCA and curcumin as building blocks to develop MA anticancer compounds with superior pharmacologic properties (Figure 2). We investigated structure activity relationship of these novel compounds on the antiproliferative potency in colorectal cancer (CRC) cells (CaCo-2, HCT-116 and HT-29). Our continued focus on CRC [21, 22] was influenced by the prevalence of this malignant disease $[23,24]$, its high morbidity and mortality rate [25], as well as the formidable problems of resistance to current available chemotherapeutic agents [26].

The rationale for designing of these compounds depended on replacement of the metabolically labile aldehyde group of tCA by a cinnamamide that extends to attach another cinnamamide to form the bis-cinnamamide scaffold (Figure-2). We investigated the structure-activity relationship (SAR) in three phases (Figure 2): the first generation was testing the designed bis-cinnamamide scaffold as a close analogue to tCA, thus $\mathrm{R}^{1}$ and $\mathrm{R}^{2}$ were fixed as unsubstituted phenyl attached to two propenamide moieties and the variation was limited to substituents on $\mathrm{R}^{3}$ that ranged from aliphatic, aromatic, heterocyclic groups. In addition, a compound in this series was an ester $(X=O)$. In the 
second generation, $\mathrm{X}-\mathrm{R}^{3}$ was fixed as $\mathrm{NH}$-propyl and the distance between the two aromatic groups $\left(\mathrm{R}^{1}\right.$ to $\mathrm{R}^{2}$ ) was varied. In a third generation, the $\mathrm{R}^{1}$ and $\mathrm{R}^{2}$ were varied simultaneously by substituted phenyl and heteraryl groups. This stepwise SAR studies helped to identify compounds with high activity against three colon cancer cell lines.<smiles>[R]C=CC(=O)NC(=C[R])C([R])=O</smiles>

Bis-(cinnamamide) scaffold Designed based on tCA MA structure

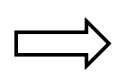<smiles>[R][X]C(=O)/C(=C\c1ccccc1)NC(=O)/C=C/c1ccccc1</smiles>

First Generation (Entries 1-20, Table 1) $\mathrm{R}=$ alkyl, aryl and heterocyclic $\mathrm{X}=\mathrm{N}, \mathrm{O}$

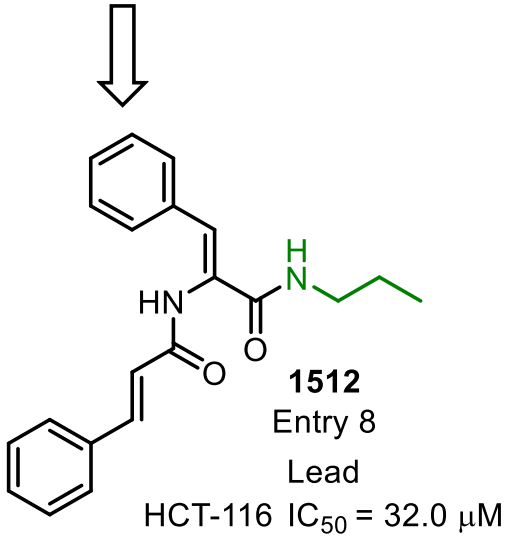

1712
Entry 22<smiles>[CH]=C</smiles>

Entry 21<smiles>CCCNC(=O)/C(=C/C=C/c1ccccc1)NC(=O)/C=C/c1ccccc1</smiles>

Second Generation: Scaffold Variants Inactive against HCT-116

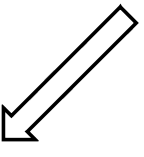<smiles>[R]C=CC(=O)NC(=C[R])C(=O)NCCC</smiles>

Third Generation:

Fix $R 3$ and vary $R^{1}$ and $R^{2}$ Entries 23-56

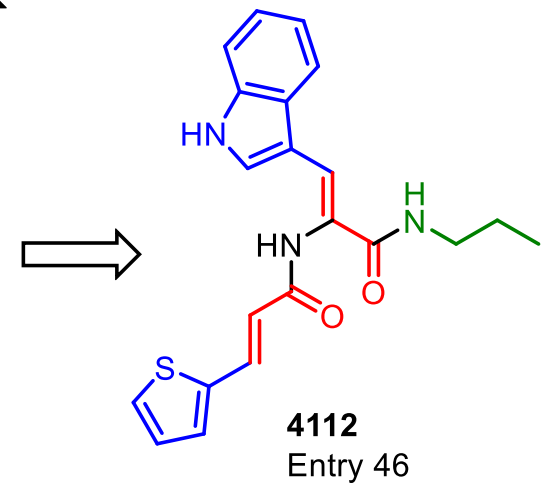

HCT-116 IC $50=2.85 \mu \mathrm{M}$ Caco-2 $\mathrm{IC}_{50}=0.89 \mu \mathrm{M}$ $\mathrm{HT}-29 \mathrm{IC}_{50}=1.65 \mu \mathrm{M}$ 
Figure 2. General structure of bis-cinnamamide scaffold and its derivatives synthesized in this research is illustrated (up and right). The colors in the structure indicate groups equivalent to tCA and curcumin illustrated in Figure 1. The SAR studies are illustrated. The entries are detailed in Table 1 below. Note that numbering of the final compounds follows the original project coding system and therefore, they are not sequential.

\section{RESULTS}

\subsection{Chemical Synthesis of 2-cinnamamido-N-substituted-cinnamamide derivatives}

The synthetic pathway for Final Compounds (Codes 1501-5612; Entries 1-56; Table 1 and Figure 2), described in scheme 1 utilized Erlenmeyer chemistry for azlactone synthesis [21]. In this scheme, non-commercially available cinnamic acid analogues 2 were prepared by condensation of the corresponding aldehyde with malonic acid [27]. After conversion to the hippuric acid analogues (3), the cyclo-condensation was affected by their reaction with the corresponding aldehydes to afford the 2-arylvinyl-4-benzylidene-5oxazolinone derivatives (azlactones, 4) under Erlenmeyer conditions [21, 28]. The key azlactone intermediate $\mathbf{3}$ was subsequently reacted with a variety of aliphatic and aromatic amines to furnish the final compounds. Generally, the aliphatic and benzylic amines were reacted with the azlactone smoothly at room temperature in ethanol. The less reactive aromatic amines needed microwave heating in the presence of $N, N$-dimethylformamide (DMF) as a solvent. The ester 15EE was prepared by solvolysis in boiling ethanol in presence of catalytic amount of 4-dimethylaminopyridine (DMAP). 


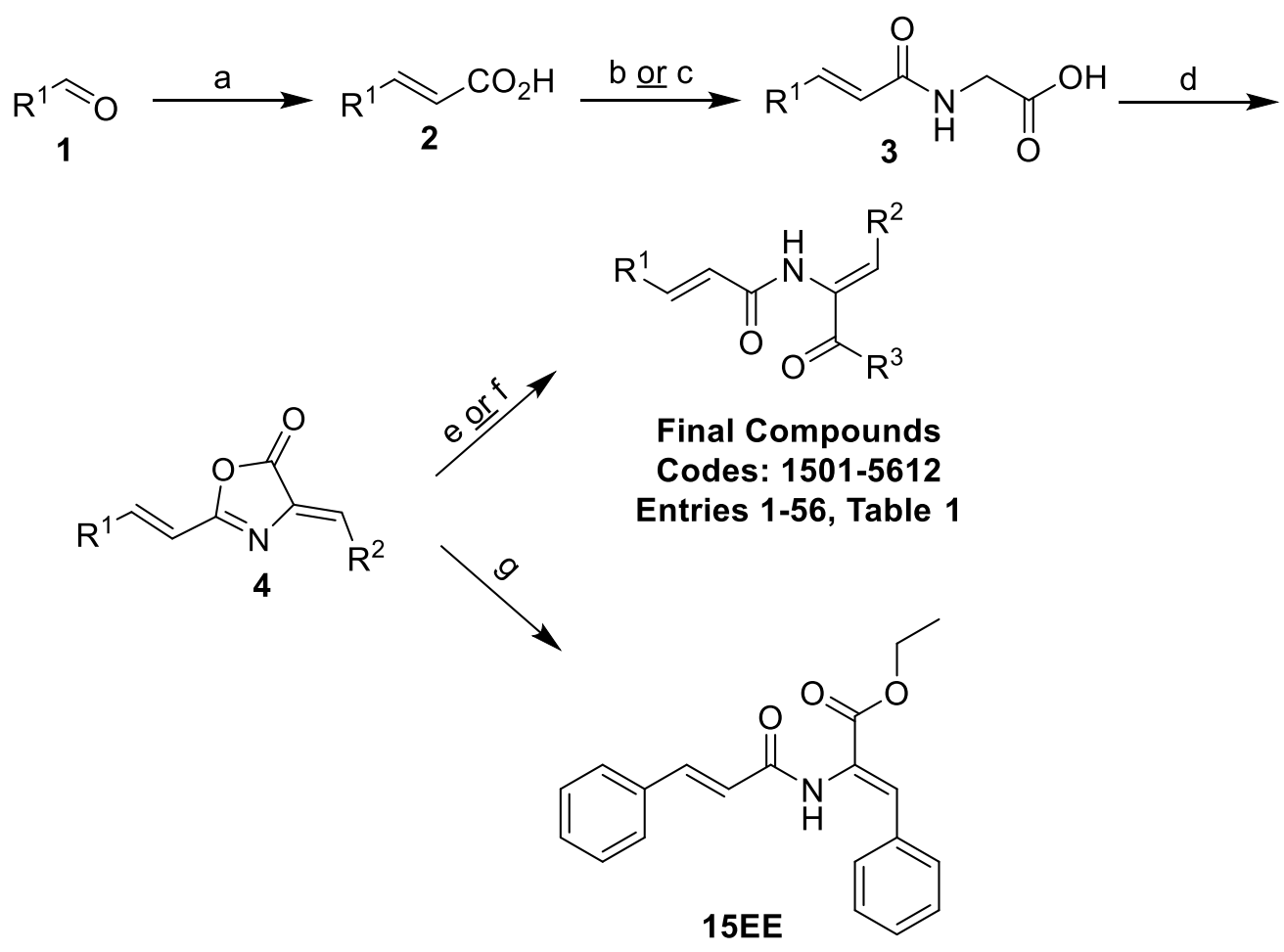

Scheme 1. Synthesis of title compounds (a) malonic acid, pyridine, heat. (b) [i] oxalyl chloride, DCM, DMF (cat.); [ii] glycine, sodium carbonate, THF, water (c) [i] ethyl glycinate hydrochloride, Et ${ }_{3} \mathbf{N}$, EDCI, DCM; [ii] $\mathrm{NaOH}$, EtOH, $\mathrm{H}_{2} \mathrm{O}$ (b) $\mathrm{R}^{2} \mathrm{CHO}$, acetic anhydride, heat; (e) aliphatic amines, ethanol, room temperature (f) aromatic amines, DMF, microwave heating; (g) EtOH, DMAP, heat, overnight. Note that numbering of the final compounds follows the original project coding system and therefore, they are not sequential.

The homologues 1612 and 1712 were prepared in similar ways starting with the appropriate azlactones (see experimental section). All compounds were confirmed using proton nuclear magnetic resonance $\left({ }^{1} \mathrm{H} \mathrm{NMR}\right)$, carbon-13 nuclear magnetic resonance $\left({ }^{13} \mathrm{C} \mathrm{NMR}\right)$ and Fourier-transform infrared (FT-IR) spectroscopic analysis. Compounds were introduced to biological screening if their purity were $95 \%$ or more in high-performance liquid chromatography at $254 \mathrm{~nm}$ UV detection. 


\subsection{Biological Screening}

\subsubsection{Antiproliferative activities of bis-cinnamamide derivatives}

Compounds in this study (Figure 2, Table 1) were tested for their cytotoxicity activities against colorectal cancer cell line HCT-116, using sulforhodamine-B (SRB) assay [29]. The first twenty compounds (Entries 1-20; Codes 1501 to 15EE), having fixed phenyl groups at $\mathrm{R}^{1}$ and $\mathrm{R}^{2}$ positions (Figure 2), showed moderate to weak antiproliferative activities (Table 1). The compound with the highest activity in this subset was the $N$-(1-adamantyl) analogue $\left(\mathbf{1 5 0 5}\right.$, Entry 4) with $\mathrm{IC}_{50}=14.7 \mu \mathrm{M}$, but with poor solubility (ClogP 6.08), while compound 1512 (Entry 2) with moderate activities $\left(\mathrm{IC}_{50}=\right.$ $32.0 \mu \mathrm{M}$ ) showed better solubility profile (CLogP 4.48). Interestingly, 1512 exhibited significantly low cancer cell resistance $(\mathrm{R}$-value $=8.2 \%)[21]$ and high selectivity in killing cancer cells (HCT-116, Caco-2 and HT-29) versus highly proliferative normal cells (C-166 mouse skin fibroblasts) (Figure 3).

\begin{tabular}{|c|c|c|c|c|c|c|c|}
\hline Entry & Code & $\mathbf{R}^{1}$ & $\mathbf{R}^{2}$ & $\mathbf{R}^{3}$ & HCT-116* & CACO-2* & HT-29* \\
\hline 1 & 1501 & $\mathrm{Ph}$ & $\mathrm{Ph}$ & $\mathrm{NHPh}$ & $75.3 \pm 3.1$ & ND & $\mathrm{ND}$ \\
\hline 2 & 1502 & $\mathrm{Ph}$ & $\mathrm{Ph}$ & $\mathrm{NH}-\mathrm{CH}_{2} \mathrm{Ph}$ & $53.6 \pm 0.6$ & ND & ND \\
\hline 3 & 1503 & $\mathrm{Ph}$ & $\mathrm{Ph}$ & NH-cyclopentyl & $48.5 \pm 3.1$ & ND & ND \\
\hline 4 & 1505 & $\mathrm{Ph}$ & $\mathrm{Ph}$ & NH-(1-adamantyl) & $14.7 \pm 0.3$ & ND & ND \\
\hline 5 & 1507 & $\mathrm{Ph}$ & $\mathrm{Ph}$ & NH-(3-pyridyl) & $>100$ & ND & ND \\
\hline 6 & 1508 & $\mathrm{Ph}$ & $\mathrm{Ph}$ & $\mathrm{NH}_{2}$ & $>100$ & ND** & ND \\
\hline 7 & 1511 & $\mathrm{Ph}$ & $\mathrm{Ph}$ & $\begin{array}{c}\text { NH-(4-methyl-1- } \\
\text { piperazinyl) }\end{array}$ & $>100$ & ND & ND \\
\hline 8 & 1512 & $\mathrm{Ph}$ & $\mathrm{Ph}$ & NH- $(n-\operatorname{Pr})$ & $32.0 \pm 2.6$ & $38.0 \pm 0.87$ & $35.5 \pm 1.7$ \\
\hline 9 & 1513 & $\mathrm{Ph}$ & $\mathrm{Ph}$ & $\mathrm{NH}-(3-\mathrm{CN}-\mathrm{Ph})$ & $>100$ & ND & ND \\
\hline 10 & 1528 & $\mathrm{Ph}$ & $\mathrm{Ph}$ & $\mathrm{NH}-(4-\mathrm{F}-\mathrm{Ph})$ & $91.9 \pm 4.4$ & ND & ND \\
\hline 11 & 1530 & $\mathrm{Ph}$ & $\mathrm{Ph}$ & NH-furfuryl & $>100$ & ND & ND \\
\hline 12 & 1531 & $\mathrm{Ph}$ & $\mathrm{Ph}$ & $\begin{array}{c}\mathrm{NH}-(2- \\
\text { morpholinoethyl) }\end{array}$ & $>100$ & ND & ND \\
\hline 13 & 1532 & $\mathrm{Ph}$ & $\mathrm{Ph}$ & NH-(2-hydroxyethyl) & $>100$ & ND & ND \\
\hline
\end{tabular}




\begin{tabular}{|c|c|c|c|c|c|c|c|}
\hline 14 & 1536 & $\mathrm{Ph}$ & $\mathrm{Ph}$ & 4-morpholinyl & $>100$ & $\mathrm{ND}$ & ND \\
\hline 15 & 1555 & $\mathrm{Ph}$ & $\mathrm{Ph}$ & 1-pyrrolidinyl & $>100$ & ND & ND \\
\hline 16 & 1556 & $\mathrm{Ph}$ & $\mathrm{Ph}$ & $\mathrm{NH}-(n-\mathrm{Bu})$ & $67.2 \pm 6.3$ & ND & ND \\
\hline 17 & 1557 & $\mathrm{Ph}$ & $\mathrm{Ph}$ & $\mathrm{NH}-(\sec -\mathrm{Bu})$ & $52.4 \pm 7.1$ & ND & ND \\
\hline 18 & 1558 & $\mathrm{Ph}$ & $\mathrm{Ph}$ & $\mathrm{NH}-\mathrm{Et}$ & $>100$ & ND & ND \\
\hline 19 & 1559 & $\mathrm{Ph}$ & $\mathrm{Ph}$ & $\mathrm{N}(\mathrm{Me}) \mathrm{Et}$ & $28.8 \pm 1.0$ & ND & ND \\
\hline 20 & 15EE & $\mathrm{Ph}$ & $\mathrm{Ph}$ & $\mathrm{OEt}$ & $>100$ & ND & ND \\
\hline 21 & 1612 & & & & $>100$ & ND & ND \\
\hline 22 & 1712 & & & & $>100$ & ND & ND \\
\hline 23 & 1812 & 4-ClPh & $\mathrm{Ph}$ & $\mathrm{NH}-(n-\mathrm{Pr})$ & $10.3 \pm 0.34$ & $10.7 \pm 0.5$ & $7.90 \pm 0.43$ \\
\hline 24 & 1912 & 4-MeOPh & $\mathrm{Ph}$ & $\mathrm{NH}-(n-\mathrm{Pr})$ & $34.1 \pm 1.8$ & $18.5 \pm 1.5$ & $55.3 \pm 3.2$ \\
\hline 25 & 2012 & 4-MePh & $\mathrm{Ph}$ & $\mathrm{NH}-(n-\mathrm{Pr})$ & $35.2 \pm 0.54$ & $12.7 \pm 0.67$ & $54.1 \pm 0.42$ \\
\hline 26 & 2112 & 2-thienyl & $\mathrm{Ph}$ & $\mathrm{NH}-(n-\mathrm{Pr})$ & $43.0 \pm 1.5$ & $27.8 \pm 1.3$ & $43.2 \pm 2.3$ \\
\hline 27 & 2212 & $\mathrm{Ph}$ & 4-FPh & $\mathrm{NH}-(n-\mathrm{Pr})$ & $15.2 \pm 1.2$ & $13.2 \pm 1.0$ & $7.20 \pm 0.31$ \\
\hline 28 & 2312 & 4-ClPh & 4-FPh & $\mathrm{NH}-(n-\mathrm{Pr})$ & $3.80 \pm 0.24$ & $2.60 \pm 0.23$ & $4.00 \pm 0.14$ \\
\hline 29 & 2412 & 4-MeOPh & 4-FPh & $\mathrm{NH}-(n-\mathrm{Pr})$ & $29.3 \pm 1.2$ & $45.7 \pm 1.2$ & $86.5 \pm 2.9$ \\
\hline 30 & 2512 & 4-MePh & 4-FPh & $\mathrm{NH}-(n-\mathrm{Pr})$ & $6.70 \pm 0.36$ & $5.10 \pm 0.17$ & $11.80 \pm 0.18$ \\
\hline 31 & 2612 & 2-thienyl & 4-FPh & $\mathrm{NH}-(n-\mathrm{Pr})$ & $17.3 \pm 0.13$ & $10.7 \pm 0.68$ & $7.68 \pm 0.05$ \\
\hline 32 & 2712 & $\mathrm{Ph}$ & 4-( $\left(\mathrm{Me}_{2} \mathrm{~N}\right) \mathrm{Ph}$ & $\mathrm{NH}-(n-\mathrm{Pr})$ & $6.95 \pm 0.46$ & $4.24 \pm 0.09$ & $6.81 \pm 0.05$ \\
\hline 33 & 2812 & 4-ClPh & 4-(Me2N)Ph & $\mathrm{NH}-(n-\mathrm{Pr})$ & $20.7 \pm 0.32$ & $17.0 \pm 0.8$ & $9.52 \pm 0.42$ \\
\hline 34 & 2912 & 4-MeOPh & 4-(Me2N)Ph & $\mathrm{NH}-(n-\mathrm{Pr})$ & $12.4 \pm 0.25$ & $15.3 \pm 0.05$ & $36.9 \pm 0.25$ \\
\hline 35 & 3012 & 4-MePh & 4-(Me2N)Ph & $\mathrm{NH}-(n-\mathrm{Pr})$ & $22.1 \pm 0.10$ & $29.4 \pm 0.08$ & $39.6 \pm 0.22$ \\
\hline 36 & 3112 & 2-thienyl & 4-(Me2N)Ph & $\mathrm{NH}-(n-\mathrm{Pr})$ & $11.6 \pm 0.39$ & $27.7 \pm 3.7$ & $66.5 \pm 0.10$ \\
\hline 37 & 3212 & $\mathrm{Ph}$ & 3-MeO-4-OHPh & $\mathrm{NH}-(n-\mathrm{Pr})$ & $>100$ & $6.32 \pm 0.02$ & $9.14 \pm 0.23$ \\
\hline 38 & 3312 & 4-ClPh & 3-MeO-4-OHPh & $\mathrm{NH}-(n-\mathrm{Pr})$ & $37.8 \pm 1.8$ & $6.14 \pm 0.44$ & $5.47 \pm 0.34$ \\
\hline 39 & 3412 & 4-MeOPh & 3-MeO-4-OHPh & $\mathrm{NH}-(n-\mathrm{Pr})$ & $38.4 \pm 2.1$ & $18.0 \pm 1.2$ & $48.6 \pm 0.4$ \\
\hline 40 & 3512 & 4-MePh & 3-MeO-4-OHPh & $\mathrm{NH}-(n-\mathrm{Pr})$ & $26.3 \pm 1.3$ & $20.9 \pm 1.1$ & $15.1 \pm 0.67$ \\
\hline 41 & 3612 & 2-thienyl & 3-MeO-4-OHPh & $\mathrm{NH}-(n-\mathrm{Pr})$ & $24.8 \pm 1.4$ & $28.3 \pm 1.3$ & $48.3 \pm 1.9$ \\
\hline 42 & 3712 & $\mathrm{Ph}$ & 3-indolyl & $\mathrm{NH}-(n-\mathrm{Pr})$ & $1.65 \pm 0.05$ & $2.1 \pm 0.03$ & $2.36 \pm 0.04$ \\
\hline 43 & 3812 & 4-ClPh & 3-indolyl & $\mathrm{NH}-(n-\mathrm{Pr})$ & $3.51 \pm 0.21$ & $3.35 \pm 0.05$ & $3.41 \pm 0.03$ \\
\hline 44 & 3912 & 4-MeOPh & 3-indolyl & $\mathrm{NH}-(n-\mathrm{Pr})$ & $4.35 \pm 0.29$ & $2.07 \pm 0.03$ & $2.49 \pm 0.04$ \\
\hline 45 & 4012 & 4-MePh & 3-indolyl & $\mathrm{NH}-(n-\mathrm{Pr})$ & $3.39 \pm 0.10$ & $2.3 \pm 0.08$ & $3.12 \pm 0.06$ \\
\hline 46 & 4112 & 2-thienyl & 3-indolyl & $\mathrm{NH}-(n-\mathrm{Pr})$ & $2.85 \pm 1.5$ & $0.89 \pm 0.04$ & $1.65 \pm 0.07$ \\
\hline 47 & 4212 & $\mathrm{Ph}$ & 3-pyridyl & $\mathrm{NH}-(n-\mathrm{Pr})$ & $73.0 \pm 2.5$ & $66.0 \pm 2.2$ & $>100$ \\
\hline 48 & 4312 & 4-ClPh & 3-pyridyl & $\mathrm{NH}-(n-\mathrm{Pr})$ & $49.4 \pm 1.9$ & $47.3 \pm 1.9$ & $36.0 \pm 1.7$ \\
\hline 49 & 4412 & 4-MeOPh & 3-pyridyl & $\mathrm{NH}-(n-\mathrm{Pr})$ & $52.1 \pm 1.6$ & $38.1 \pm 2.0$ & $72.7 \pm 6.4$ \\
\hline 50 & 4512 & 4-MePh & 3-pyridyl & $\mathrm{NH}-(n-\mathrm{Pr})$ & $>100$ & $27.0 \pm 1.8$ & $>100$ \\
\hline 51 & 4612 & 2-thienyl & 3-pyridyl & $\mathrm{NH}-(n-\mathrm{Pr})$ & $>100$ & $41.8 \pm 1.4$ & $68.8 \pm 6.9$ \\
\hline 52 & 4712 & $\mathrm{Ph}$ & $4-\mathrm{NO}_{2} \mathrm{Ph}$ & $\mathrm{NH}-(n-\mathrm{Pr})$ & $17.3 \pm 1.3$ & $44.2 \pm 2.7$ & $23.2 \pm 1.9$ \\
\hline
\end{tabular}




\begin{tabular}{|c|c|c|c|c|c|c|c|}
\hline $\mathbf{5 3}$ & $\mathbf{4 8 1 2}$ & $4-\mathrm{ClPh}$ & $4-\mathrm{NO}_{2} \mathrm{Ph}$ & $\mathrm{NH}-(n-\mathrm{Pr})$ & $>100$ & $>100$ & $36.9 \pm 1.5$ \\
\hline $\mathbf{5 4}$ & $\mathbf{4 9 1 2}$ & $4-\mathrm{MeOPh}$ & $4-\mathrm{NO}_{2} \mathrm{Ph}$ & $\mathrm{NH}-(n-\mathrm{Pr})$ & $>100$ & $>100$ & $74.3 \pm 3.6$ \\
\hline $\mathbf{5 5}$ & $\mathbf{5 0 1 2}$ & $4-\mathrm{MePh}$ & $4-\mathrm{NO}_{2} \mathrm{Ph}$ & $\mathrm{NH}-(n-\mathrm{Pr})$ & $>100$ & $>100$ & $>100$ \\
\hline $\mathbf{5 6}$ & $\mathbf{5 1 1 2}$ & 2-thienyl & $4-\mathrm{NO}_{2} \mathrm{Ph}$ & $\mathrm{NH}-(n-\mathrm{Pr})$ & $>100$ & $34.2 \pm 1.1$ & $>100$ \\
\hline $\mathbf{5 7}$ & $\mathbf{t C A}$ & & & & $12.4 \pm 1.2$ & $\mathrm{ND}$ & $\mathrm{ND}$ \\
\hline $\mathbf{5 8}$ & Doxorubicin & & & & $0.613 \pm 0.10$ & $0.147 \pm .01$ & $0.325 \pm 0.01$ \\
\hline
\end{tabular}

Table 1. Cytotoxic activities of final compounds on colon cancer cell lines. Note that numbering of the final compounds follows the original project coding system and therefore, they are not sequential. *IC50 values in $\mu \mathrm{M} \pm$ Standard Error of Means (SEM). **ND, Not Determined.

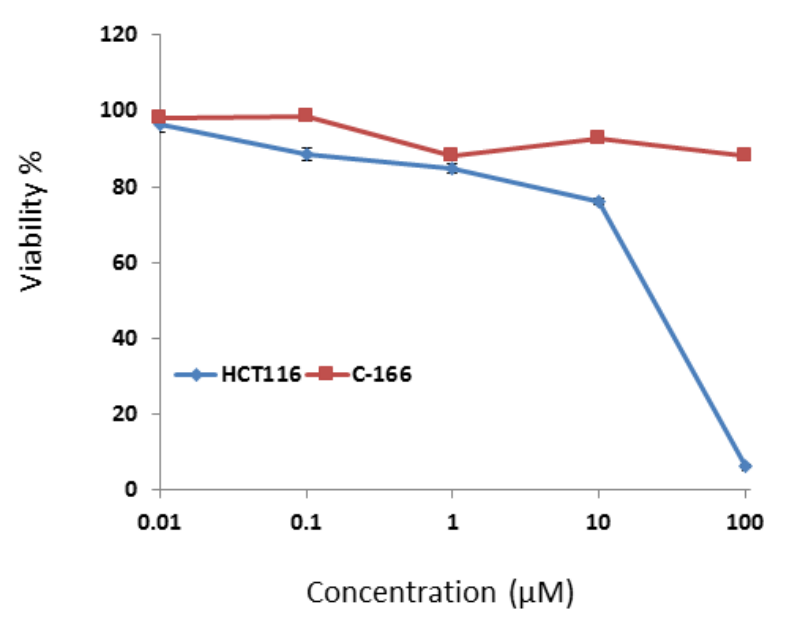

Figure 3. Dose-response curve of compound 1512 on HCT-116 cell lines (blue) and C-166 cell line (brown).

Based on 1512 favorable biological properties (see Supplementary Material, Section S1 for more details on cellular mechanisms of this lead), it was selected as a new lead for the second subset of compounds (Entries 23 to $\mathbf{5 6}$; Codes 1812 to $\mathbf{5 6 1 2}$ ) with fixed $\mathrm{R}^{3}$ as propyl (based on 1512 structure) but diversified at $\mathrm{R}^{1}$ and $\mathrm{R}^{2}$ (Figure 2). The new compounds were tested against three CRC cell lines (HCT-116, Caco-2 and HT-29). Some of these compounds showed high potencies comparable to the reference drug doxorubicin (Table 1). For instance, entries $28,32,42,43,44,45$ and 46 demonstrated excellent potencies (5.0 
$\mu \mathrm{M}$ or less) with compound 4112 (Entry 46) demonstrating the most significant growth inhibition against all tested cell lines. The $\mathrm{IC}_{50}$ values for $\mathbf{4 1 1 2}$ against HCT-116, Caco-2, and HT-29 cells were 2.85, 0.89 and $1.65 \mu \mathrm{M}$, respectively; compared to doxorubicin 0.60 , 0.14, and $0.30 \mu \mathrm{M}$, respectively. Additionally, compound $\mathbf{4 1 1 2}$ had excellent selectivity against cancer cells versus baby hamster kidney $(\mathrm{BHK})$ cell lines $\left(\mathrm{IC}_{50}=77.6 \mu \mathrm{M}\right)$. Also, notable is another potent compound 3712, which exhibited $\mathrm{IC}_{50}$ of $1.65,2.1 \mu \mathrm{M}$ and 2.36 against HCT-116, Caco-2, and HT-29 cells, respectively.

\begin{tabular}{|c|c|c|}
\hline $\begin{array}{c}\text { Entry } \\
\text { (Table 1) }\end{array}$ & Code & $\begin{array}{c}\text { Non-cancerous cell } \\
\text { line } \mathbf{I C}_{\mathbf{5 0}}(\boldsymbol{\mu M} \mathbf{M})\end{array}$ \\
\hline 2 & 1512 & $>100^{*}$ \\
\hline 28 & 2312 & $21.2 \pm 1.93^{* *}$ \\
\hline 32 & 2712 & $75.7 \pm 1.64 * *$ \\
\hline 38 & 3312 & $89.9 \pm 10.4 * *$ \\
\hline 42 & 3712 & $>100^{* *}$ \\
\hline 46 & 4112 & $71.7 \pm 5.12^{* *}$ \\
\hline 58 & tCA & $63.9 \pm 13.0^{* *}$ \\
\hline
\end{tabular}

Table 2. Cytotoxic activities of selected compounds against healthy (non-cancerous) cell lines. $* \mathrm{C}-166$ cell lines (Mouse skin fibroblast). ** BHK (Baby hamster kidney) cell lines.

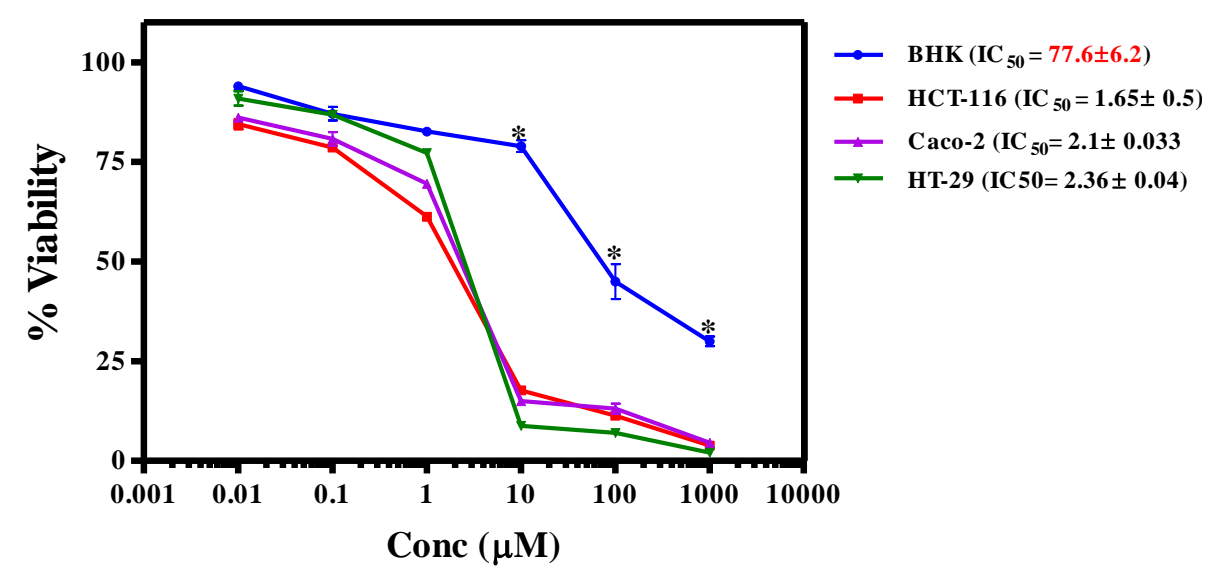

Figure 4. Cytotoxic effect of 4112 against human colon adenocarcinoma cancer cells (HCT-116, Caco-2 and HT-29) vs. normal baby hamster kidney cells (BHK). All cells were exposed to different concentrations of 4112 for $72 \mathrm{~h}$. The cell viability concentration curves were plotted, and the IC50 were determined. *denotes significance at $\mathrm{P}<0.001$ 


\subsubsection{Induction of apoptosis and apoptotic changes in HCT-116 cancer cell lines upon treatment with 4112.}

The apoptotic effect of $\mathbf{4 1 1 2}$ on HCT-116 cells [30] was investigated by the DAPI staining test after incubation of HCT-116 cells with the compound at $3.00 \mu \mathrm{M}$. The result clearly shows that the ratio of cells with fragmented DNA and condensed nuclei are higher than that of untreated cells (control), which significantly increased after $48 \mathrm{~h}$ compared to $24 \mathrm{~h}$ (Figure 5).

In a subsequent experiment, 4112-treated HCT-116 cells (at $3.00 \mu \mathrm{M}$ ) were monitored for apoptotic changes at $24 \mathrm{~h}$ and $48 \mathrm{~h}$ using flow cytometry analysis after staining with Annexin V/Propidium iodide (Figure 6). This dual staining allows discrimination between live cells (annexin-V-/PI-), early apoptotic cells (annexin-V+/PI-), late apoptotic cells (annexin-V+/PI+) and necrotic cells (annexin-V-/PI+) Compound 4112 induced both early and late apoptosis in HCT-116 cells in a time-dependent manner when compared to the untreated control cells. At $24 \mathrm{~h}$, there was very little change in cell viability, but decreased to $72 \%$ (down from $99.9 \%$ ) after $48 \mathrm{~h}$. Notably, the cell populations at $48 \mathrm{~h}$ in both early and late apoptosis increased from almost zero to $17.5 \%$ and $4.1 \%$, respectively. 

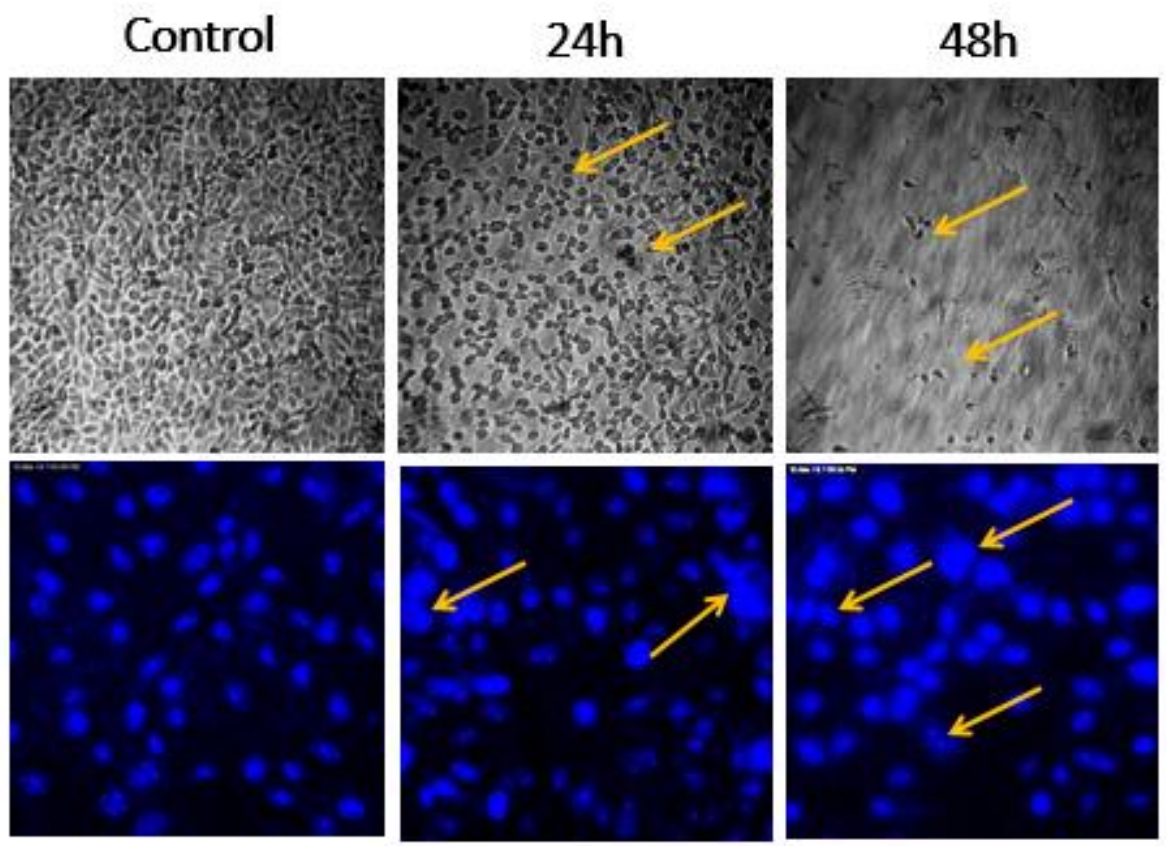

Figure 5. Morphological changes in HCT-116 cells following exposure to compound 4112. The cells were left untreated or treated with the $\mathrm{IC}_{50}$ for 24 and $48 \mathrm{~h}$. Pictures at top show the morphological changes examined under light microscope. Images at the bottom show the nuclei stained with DAPI and visualized under fluorescence microscope. Arrows point to apoptotic cells.
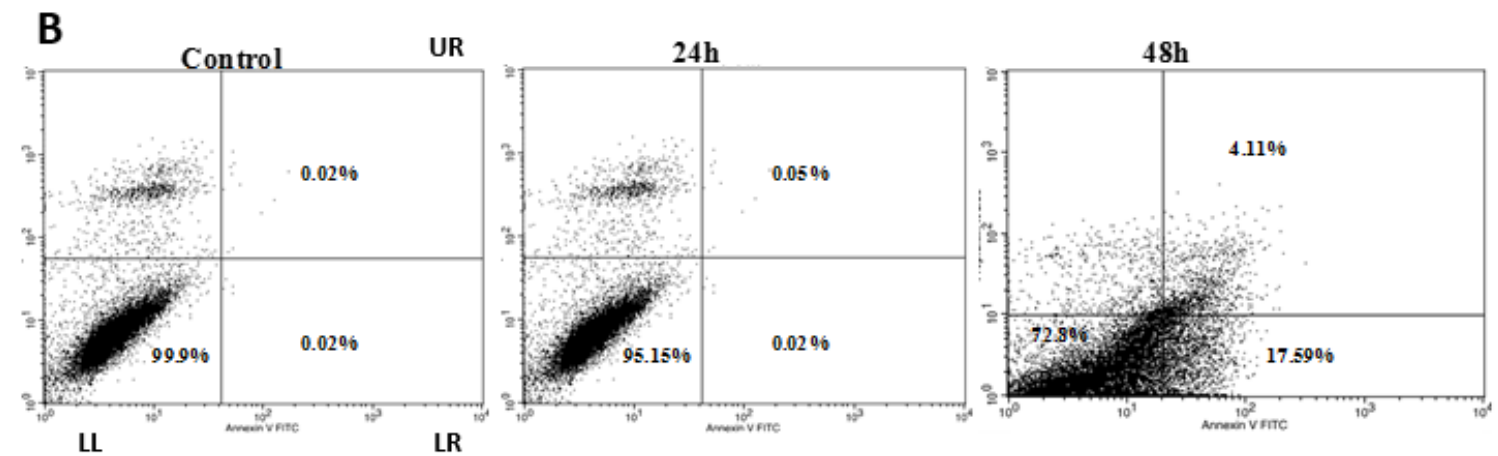

Figure 6. Effect of 4112 on HCT-116 cell cycle progression: Key, $L L=$ Viable cells, $L R=$ Early apoptotic cells, $\mathbf{U R}=$ Late apoptosis. 


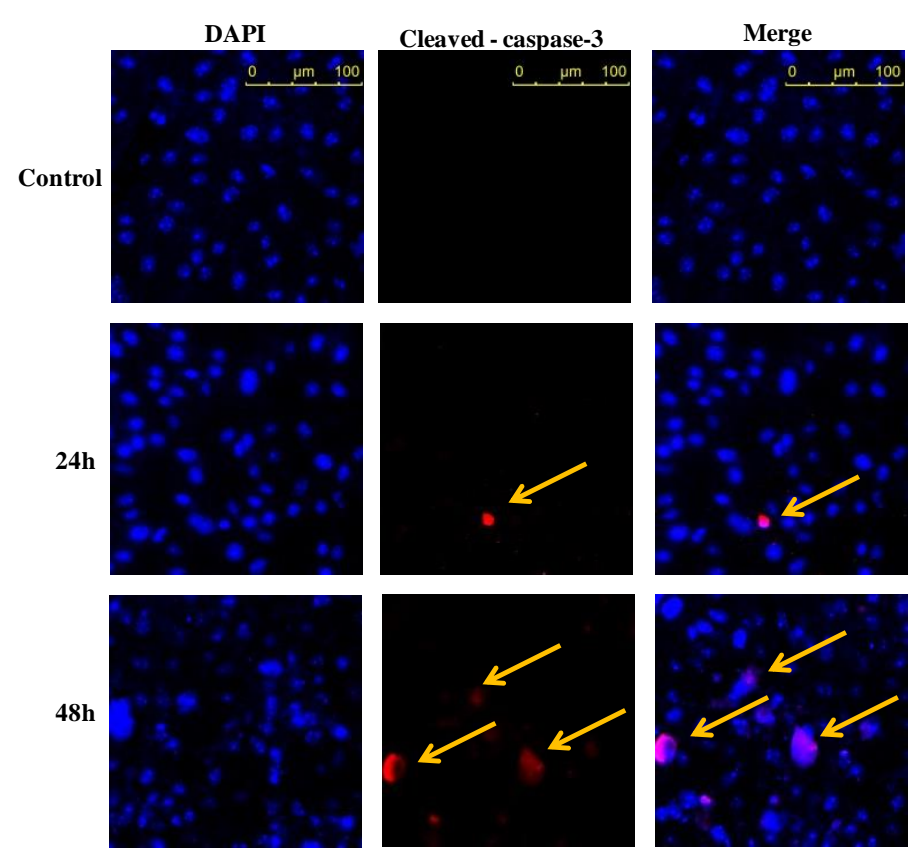

Figure 7. Effect of 4112 on cleaved caspase-3 expression in HCT-116 cells. The cells were stained with DAPI to visualize nuclei (blue) and with Alexa Fluor 488- and Cy3-coupled secondary antibodies to visualize the distribution of caspase- 3 (red). Scale bar, $100 \mu \mathrm{m}$

The compound $\mathbf{4 1 1 2}$ also caused increase levels of cleaved caspase 3 in a time-

dependent manner (24 and $48 \mathrm{~h}$ ), indicating nuclear release of this apoptotic marker upon treatment with 4112 (Figure 7).

\subsubsection{Elevation of oxidative stress indicators within HCT-116 cells upon treatment}

with 4112.

ROS release, as an indicator for increased oxidative stress, was monitored over time (24 and 48 h) by using 2`,7-dichlorofluorescin diacetate (DCFDA) dye which detects various ROS species and emit green fluorescence. It is clear that $\mathbf{4 1 1 2}$ causes accumulation of ROS in HCT-116 cells, which is proportional to the time of exposure (Figure 8). 


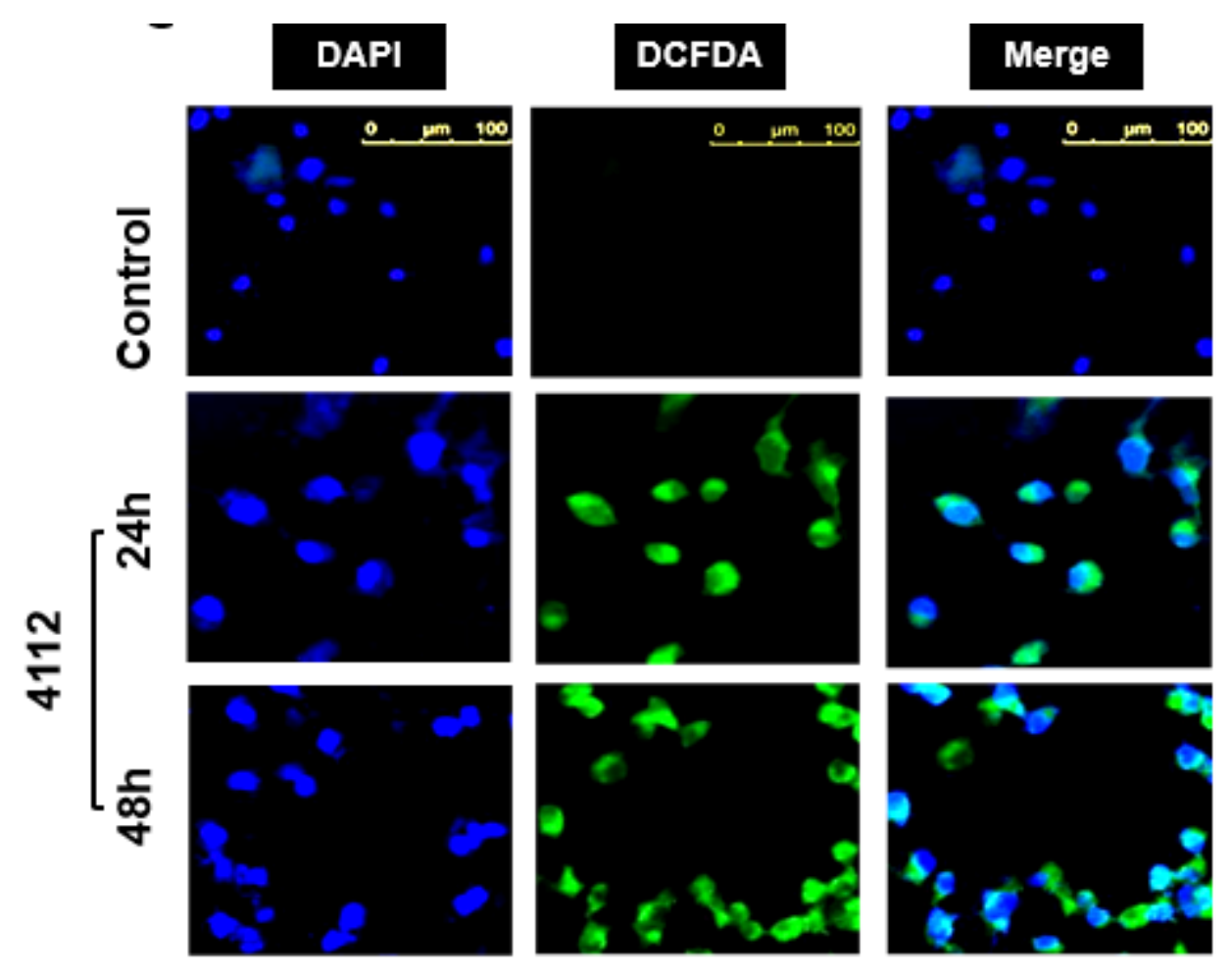

Figure 8. Effect of 4112 on ROS production from HCT-116 cells using DCFDA staining. Green fluorescence represents DCFDA staining and DAPI was used as counter nuclear staining. Scale bar, $100 \mu \mathrm{m}$.

\subsubsection{Effect of Pre-treatment with Antioxidants on Cellular Viability}

To investigate the potential effects of compound $\mathbf{4 1 1 2}$ on ROS levels in HCT-116 colon cancer cells, we employed a viability assay in which cells were pre-incubated with the antioxidant N-acetyl cysteine (NAC) or the vitamin E derivative Trolox (6-hydroxy2,5,7,8-tetramethylchroman-2-carboxylic acid) prior to treatment with 4112 (Figure 1). It worthy to mention that the antioxidant concentrations used in this test had no effect on cell viability.

As shown in Figure 9, pre-treatment with NAC for $1 \mathrm{~h}$ had a dramatic protective effect on HCT-116 cells at the higher concentrations $(50,25 \mu \mathrm{M})$ of compound 4112. Specifically, NAC at $10 \mathrm{mM}$ markedly increased the viable cells from 34\% (4112 alone, $50 \mu \mathrm{M}$ ) and $55 \%(4112$ alone, $25 \mu \mathrm{M})$ to $89 \%$ at $24 \mathrm{~h}$, respectively. The increase in viability of cells 
pre-treated with NAC became modest at $48 \mathrm{~h}(40 \%$ at $50 \mu \mathrm{M})$ and minimal at $72 \mathrm{~h}$. No significant increases in cell viability were noted when cells were pre-treated with Trolox.

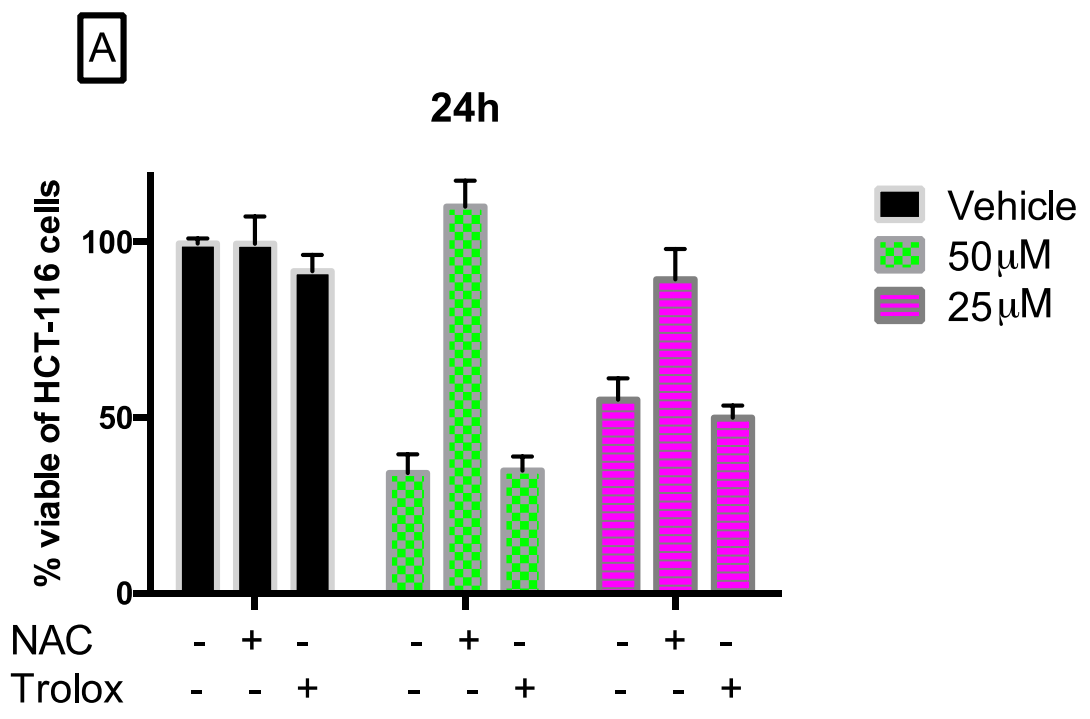

B

$48 h$

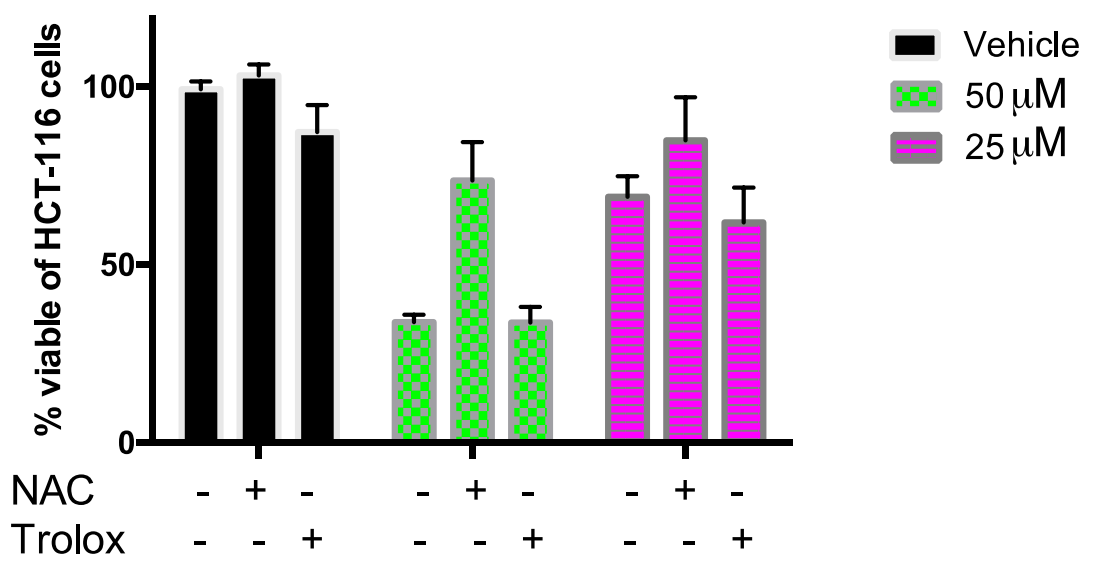




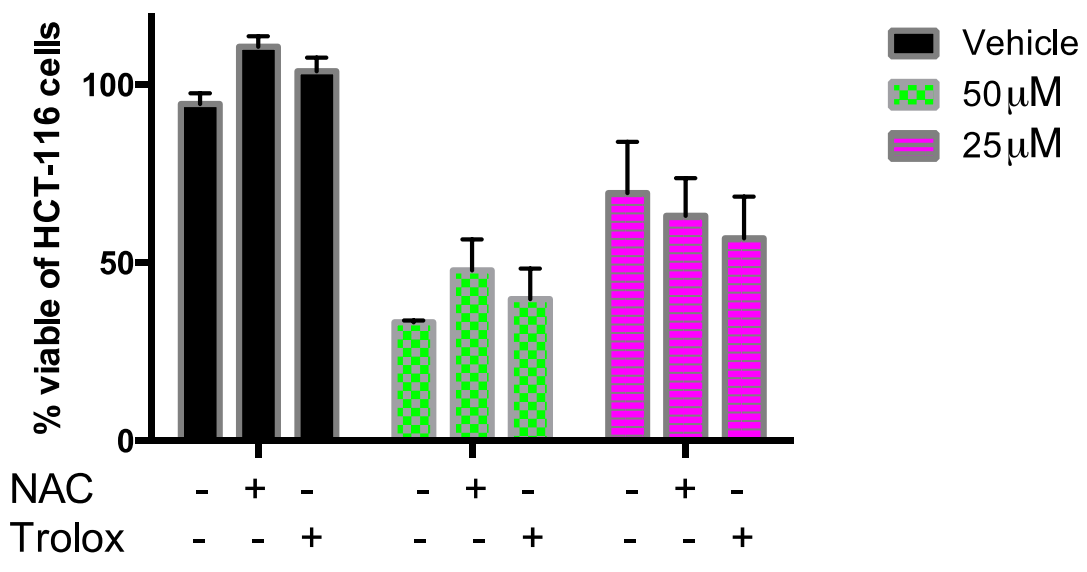

Figure 9: Effect of antioxidant pre-treatment on viability of HCT-116 cells treated with 4112. HCT116 cells were seeded at a density of $5 \times 10^{4}$ cells/ $\mathrm{ml}$ in 96 well plates and left overnight to adhere. Cells were then pre-treated with NAC $(10 \mathrm{mM})$ or Trolox $(100 \mu \mathrm{M})$ for $1 \mathrm{~h}$, followed by compound $4112(50,25 \mu \mathrm{M})$. For $24 \mathrm{~h}(\mathrm{~A}), 48 \mathrm{~h}(\mathrm{~B}), 72 \mathrm{~h}(\mathrm{C})$. Cell viability was expressed as a percentage of vehicle control [ethanol 1\% (v/v)] and was measured by MTT assay (average of three independent experiments).

\subsubsection{Inhibition of cancer stem cell proliferation in HT-29 cancer cell lines upon}

\section{treatment with 3712 and 4112}

We also evaluated 4112, and another potent compound $\mathbf{3 7 1 2}$ for their ability to inhibit cancer stem cell proliferation using a primary $\left(1^{\circ}\right)$ colonosphere formation assay. In this assay, HT-29 colon cancer cells were grown in low adhesion plates to form spheres as previously described.[31] Wells treated with our compounds were compared to vehicle treated cells for primary sphere growth inhibition after 5 days of incubation. Results, as illustrated in figure 4 , showed a dose-dependent inhibition of colon cancer spheroids formation $(>50 \mu \mathrm{m})$. The $\mathrm{IC}_{50}$ of the two compounds were 21.12 and $18.85 \mu \mathrm{M}$ for 3712 and 4112 respectively, reflecting similar closeness in potency as in HT-29 monolayer cell line assay ( 2.36 and $1.65 \mu \mathrm{M}$, respectively). Of note, monolayer growth 
conditions are ideally suited for examining cellular proliferation, whereas spheroid growth conditions examine cancer stem cell growth and self-renewal properties. Hence, differential potency of the molecules in the two condition is reflective of their effects on two different phenotypes.

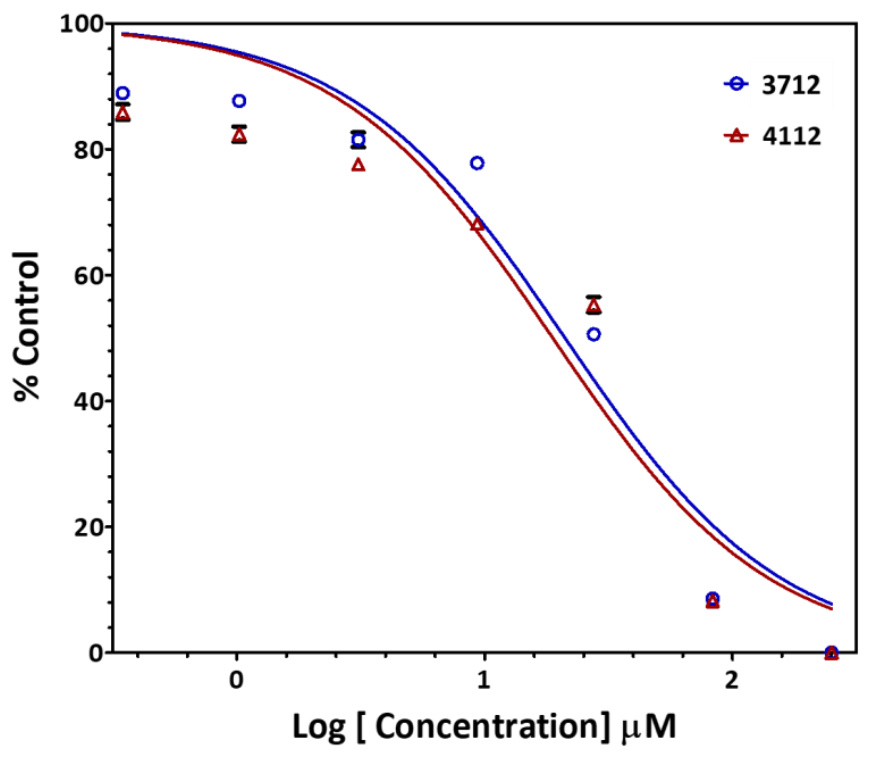

Figure 10. Dose-response curve of HT-29 cell spheroids (expressed as \% of vehicle treated cells) by increasing concentration of 3712 (blue) and 4112 (red).

\subsubsection{Lethal dose toxicity test for 4112}

Since compounds with electrophilic properties, e.g. MA are usually involved in variety of toxic effects on mammalians, we decided to investigate the general acute toxicity of 4112 by determining the in vivo lethal dose ( $\mathrm{LD}_{50}$ ) according to the Globally Harmonized Classification System (GHS) and following the OECD guideline 423 (modified, adopted March 23, 2006). As observed in our cellular assay, the compound 
safety was confirmed to be in the highest category, as the $\mathrm{LD}_{50}$ for all compounds were between 2000-5000 mg/kg (Category 5) [32].

\section{DISCUSSION}

Toward the goal of developing novel chemotherapeutic agents, we designed and synthesized several 2-cinnamamido-N-substituted-cinnamamide (bis-cinnamamide) compounds. Some of these compounds showed high potency against three CRC cancer cell lines, and in a few cases, were comparable to doxorubicin. The straight forward Erlenmeyer chemistry enabled SAR studies in three stages. First set of compounds (Entries 1-20, Table 1) varied only at the $\mathrm{R}^{3}$ substituent. Despite the moderate to weak antiproliferative effects of this series, it provided the intended outcome, a lead with confirmed activities against cancer cell lines, clear SAR and good selectivity of cytotoxicity of cancer cell lines over non-cancerous highly proliferative cell lines. In a cell line inhibition assay against the CRC cell line HCT-116, it was clear that hydrophobic $\mathrm{R}^{3}$ substituents (e.g. compounds 1505 (NH-adamantyl), 1512 (NH- $n$ propyl), 1556 (NH-n-butyl), 1557 (NH-sec-butyl) and 1559 (N-(Me)(Et)) demonstrated superior activities when compared to their hydrophilic counterparts (e.g. compounds 1511 (NH-(4-methyl-1-piprazinyl), 1530 (NH-furfuryl), 1531(NH-(2-morpholinoethyl), 1532 (NH-(2-hydroxyethyl) and 1536 (4-morpholinyl). This SAR aspect is highlighted by comparing the activities of compounds 1532 and 1512, where the more hydrophilic compound 1532 is relatively inactive while $\mathbf{1 5 1 2}$ shows moderate activity despite differing from 1532 only by a terminal methyl instead of the terminal hydroxyl group of 1532. Compounds bearing aromatic hydrophobic amides (e.g. compounds 1501(NHPh), $1502\left(\mathrm{NH}-\mathrm{CH}_{2} \mathrm{Ph}\right)$ and $1513(\mathrm{NH}-(3-\mathrm{CN}-\mathrm{Ph})$ showed lower antiproliferative activities 
compared to aliphatic hydrophobic compounds, likely due to poor physico-chemical properties. The primary amide 1508 and the ester $15 \mathrm{EE}$ also were among the weakly active compounds.

The promising results of $\mathbf{1 5 1 2}$ suggested that this compound is a viable lead for further optimization. In a limited set of only 2 compounds, the scaffold optimal size was investigated that have the distance between the two aromatic rings were changed by contracting (1612) and expanding this distance (1712) respectively. Both compounds showed almost no activity at concentrations as high as $100 \mu \mathrm{M}$ against HCT-116 cells, suggesting that keeping the distance between the two aromatic rings in compound $\mathbf{1 5 1 2}$ at 6 atoms is important for activity.

The third-generation compounds (Fixed $\mathrm{R}^{3}$ as $n$-propyl and varied at $\mathrm{R}^{1}$ and $\mathrm{R}^{2}$ ) also showed a consistent SAR when tested against the CRC cell lines HCT-116, Caco-2 and HT-29. For instance, the variation in $\mathrm{R}^{2}$ position between electron-deficient and electron-withdrawing aromatic moieties demonstrated a strong correlation between electron density over the $\mathrm{R}^{2}$ ring and activity. Rings with higher electron density (4dimethylaminophenyl, 4-hydroxy-3-methoxyphenyl and 3-indolyl) as exemplified by compounds 2312, 2712, 3312, 3712-4112 exerted potent antiproliferative activities against cancer cells in the low micromolar range $(0.89$ to $6.9 \mu \mathrm{M})$. Some of these compounds exhibited low activity against the non-cancerous cell lines BHK (Table 2). On the other hand, electron-deficient $\mathrm{R}^{2}$ aryl groups showed almost no antiproliferative activity against the cancer cell lines, exemplified by compounds 4212 to 4612 (Entries 46-51, Table 1) where $\mathrm{R}^{2}=$ 3-pyridyl; and $\mathbf{4 7 1 2}$ to $\mathbf{5 1 1 2}$ (Entries 52-56, Table 1) where $\mathrm{R}^{2}=$ 4-nitrophenyl. Notably, unlike $\mathrm{R}^{2}$, variations at the $\mathrm{R}^{1}$ position affected anticancer activities less 
significantly. In this regard, all compounds bearing 3-indolyl group at $\mathrm{R}^{2}$ were highly active regardless of the structure of the groups at $\mathrm{R}^{1}$. Meanwhile, all compounds with electron withdrawing groups at $\mathrm{R}^{2}$ (such as 3-pyridyl and 4-nitrophenyl) were much less active, and this was also irrelevant to the structure of $\mathrm{R}^{1}$.

The most potent compounds in 2-cinnamamido-N-substituted-cinnamamide (biscinnamamide) series were the 3-indolyl derivatives (3712 to 4112) which proved to be the most active against all the three cell lines. Compounds 3712 and $\mathbf{4 1 1 2}$ showed almost comparable potency as doxorubicin (the positive control) on all of the tested cell lines. For instance, Caco-2 $\mathrm{IC}_{50}$ for $\mathbf{4 1 1 2}$ was $0.89 \mu \mathrm{M}$ compared to $0.14 \mu \mathrm{M}$ for doxorubicin. The same compound exhibited about 100 times weaker antiproliferative effect on C-166 (IC 50 $=71 \mu \mathrm{M})$ compared to Caco2 cancer cell line $(0.89 \mu \mathrm{M})$. The low toxicity of $\mathbf{4 1 1 2}$ was also confirmed by a preliminary $\mathrm{LD}_{50}$ test.

Recently, models of anticancer activities are increasingly associated with activities of compounds on cancer cell aggregates. Similar to normal stem cells, cancer stem cells (CSCs) reside in niches characterized by hypoxia and low reactive oxygen species (ROS), both of which are critical for maintaining the potential for self-renewal and stemness.[33] Consistently, CSCs show low intracellular ROS levels, suggesting that maintaining a reduced intracellular environment is associated with an undifferentiated state [34]. We, therefore, tested the effect of $\mathbf{3 7 1 2}$ and $\mathbf{4 1 1 2}$ on CSCs in a cancer colonosphere formation assay, which is designed to screen for molecules that selectively target colorectal CSCs [31]. Results of the CSC inhibition test showed clear concentration-dependent inhibition of sphere size; corroborating results from other experiments. 
Since the whole series of 2-cinnamamido-N-substituted-cinnamamide (biscinnamamide) compounds was based on MA scaffold of tCA, cellular changes leading to cancer cell growth inhibition confirmed that ROS elevation (Figure 8) is a major contributor of 4112 HCT-116 cytotoxic activities. Moreover, the attenuation of 4112 cytotoxicity by the antioxidant NAC was another evidence of ROS involvement in the cell death process. Being responsible for cancer recurrence after chemotherapy or radiotherapy, CSC targeting via ROS holds a great promise in cancer therapy.

Annexin-V staining-flow cytometry method (Figure 6) confirmed the apoptotic events upon exposure to $\mathbf{4 1 1 2}$. The compound induced time-dependent increase in cell population entrance to both early and late apoptosis. The cell apoptosis, induced by $\mathbf{4 1 1 2}$, was also confirmed by increased levels of cleaved caspase- 3 and its release through the nuclear membrane (Figure 7). In agreement with the above mentioned Annexin-V staining assay result, $\mathbf{4 1 1 2}$ induces apoptosis via activation of caspases 3.

In conclusion, this work presents a model of molecular discovery of promising MA compounds to be further optimized as anticancer agents especially for colorectal cancer. These compounds showed selective toxicity against cancer cell lines and CSC over noncancerous cells, low animal toxicity, and clear cell death mechanism. The two most potent compounds, $\mathbf{3 7 1 2}$ and $\mathbf{4 1 1 2}$ will be subjected to more SAR investigations, as well as antitumor activities in future studies. 


\section{MATERIALS AND METHODS}

\subsection{Chemical Synthesis}

Solvents and reagents were purchased from Sigma-Aldrich (USA), VWR (USA) or Alfa Aesar (UK). When needed, solvents were dried according procedures described in literature. Unless stated otherwise, reactions were performed under inert atmosphere of nitrogen. Microwave reactions (MW) were performed using Milestone StartSynth ${ }^{\mathrm{TM}}$ reactor (Milestone Inc., Italy). Melting points (Mp) were determined in open capillary tubes using Electrothermal apparatus (Stuart, UK) and are uncorrected. NMR were recorded on Bruker DPX-300 MHz (Bruker, Switzerland). HPLC-Mass Spectrometry were performed on Agilent 1100 / ZQ MSD including C18 column and diod-array UV detector. The mobile phase (containing $0.01 \mathrm{M}$ ammonium acetate) was gradient starting from $20 \%$ acetonitrile/ $80 \%$ water to $80 \%$ acetonitrile/20\% water. Purities are reported according to percentage of Peak Areas at wavelength $254 \mathrm{~nm}$. According to LC/MS analyses, all compounds in this study were confirmed to have $95 \%$ purity or higher. Infrared spectra were recorded on a Thermo Scientific Nicolet iS10 Fourier transform (FT)-IR Spectrometer. In this report, we only listed the important IR stretching bands, including $\mathrm{NH}, \mathrm{OH}, \mathrm{CH}$, $\mathrm{C}=\mathrm{O}, \mathrm{C}=\mathrm{N}$ and/or $\mathrm{C}=\mathrm{C}$. In FT-IR, all samples were measured neatly

The previously reported azlactone 3[35], the final 2-aminopropenamide derivatives 1501[36], 1502[35], 1508[37] and 15EE[35, 38], and 1712[21] were prepared according 
to procedures mentioned below, and their physical and spectral properties were confirmed.

Purity of compounds were first assessed qualitatively using Thin Layer Chromatography (TLC), ${ }^{1} \mathrm{H}$ NMR and quantitatively using LC/MS (UV detection). The compounds were screened only if purity was confirmed to be above $95 \%$. The compounds subjected to all biological screenings were used as a single $Z$ isomer as detected by TLC, LC/MS and NMR.

\subsection{1. (Z)-2-cinnamamido-N,3-diphenylacrylamide (1501)[35, 39]}

In the reaction tube of the microwave reactor (Milestone ${ }^{\mathrm{TM}}$, SynthLab), oxazolone $3(2 \mathrm{mmol}, 0.554 \mathrm{~g})$ and aniline $(2 \mathrm{mmol}, 0.193 \mathrm{~mL})$ were added to $5 \mathrm{~mL}$ of DMF. The reaction was heated to $200^{\circ} \mathrm{C}$ with stirring for $10 \mathrm{~min}$. After cooling, the mixture was added slowly to ice-cold $1 \mathrm{M} \mathrm{HCl}$. The resulting solid was collected by filtration, washed with water and purified using silica gel chromatography (petroleum ether / DCM / $\mathrm{MeOH}$, gradient). The final compound $\mathbf{1 5 0 1}$ was collected as a white solid (0.520 g, 70.6\%), Mp $129-132{ }^{\circ} \mathrm{C} .{ }^{1} \mathrm{H}$ NMR $\left(600 \mathrm{MHz}\right.$, acetone- $\left.d_{6}\right) \delta_{\mathrm{H}} \mathrm{ppm} 9.50$ (1H, br. s), 9.11 (1H, br. s), 7.80 $(\mathrm{d}, J=7.53 \mathrm{~Hz}, 2 \mathrm{H}), 7.60-7.69(\mathrm{~m}, 6 \mathrm{H}), 7.38-7.49(\mathrm{~m}, 6 \mathrm{H}), 7.30-7.37(\mathrm{~m}, 4 \mathrm{H}), 7.17$ (s, $1 \mathrm{H}), 7.06-7.12(\mathrm{~m}, 1 \mathrm{H}), 7.02(\mathrm{~d}, J=15.81 \mathrm{~Hz}, 1 \mathrm{H})$.

\subsection{2. (Z)-N-benzyl-2-cinnamamido-3-phenylacrylamide (1502)[35, 38]}

Oxazolone 3 (10 mmol, $2.773 \mathrm{~g}$ ) was dissolved in $50 \mathrm{~mL}$ ethanol, benzylamine (20 mmol, $2.18 \mathrm{~mL}$ ) was then added, and the mixture was stirred for $2 \mathrm{~h}$. The solvent was removed under reduced pressure. The residue was treated with ice-cooled dilute $\mathrm{HCl}$ resulting in precipitation of a off-white solid product. The crude product was purified by crystallization from ethanol. The purified product 1502 was an off-white solid, (0.45 g, 60\%), Mp. 198$199{ }^{\circ} \mathrm{C} .{ }^{1} \mathrm{H}$ NMR $\left(600 \mathrm{MHz}\right.$, Acetone- $\left.d_{6}\right) \delta_{\mathrm{H}}$ ppm 8.08 (br. s., $\left.1 \mathrm{H}\right), 7.57$ - 7.68 (m, $\left.5 \mathrm{H}\right)$, 
7.36-7.48 (m, $8 \mathrm{H}), 7.29-7.35(\mathrm{~m}, 4 \mathrm{H}), 7.24(\mathrm{t}, J=7.34 \mathrm{~Hz}, 1 \mathrm{H}), 6.96(\mathrm{~d}, J=15.43 \mathrm{~Hz}$, $1 \mathrm{H}), 4.52-4.58(\mathrm{~m}, 2 \mathrm{H}), \mathrm{LC}-\mathrm{MS}$ (ESI), RT = $4.4 \mathrm{~min}, \mathrm{~m} / \mathrm{z} 383.1[\mathrm{M}+\mathrm{H}]^{+}$.

\subsection{3. (Z)-2-cinnamamido- $N$-cyclopentyl-3-phenylacrylamide (1503)}

This compound was prepared according to the procedure described for the synthesis of 1502 starting from oxazolone 3 ( $2 \mathrm{mmol}, 0.554 \mathrm{~g}$ ) and cyclopentylamine ( $2 \mathrm{mmol}, 0.195$ $\mathrm{mL})$. The product 1503 was a white solid, $(0.51 \mathrm{~g}, 73 \%), \mathrm{Mp} 239^{\circ} \mathrm{C} .{ }^{1} \mathrm{H}$ NMR $(600 \mathrm{MHz}$, acetone- $\left.d_{6}\right) \delta_{\text {н }}$ ppm $8.85(\mathrm{~s}, 1 \mathrm{H}), 7.59-7.67(\mathrm{~m}, 2 \mathrm{H}), 7.55(\mathrm{~d}, J=7.53 \mathrm{~Hz}, 2 \mathrm{H}), 7.40-7.47$ (m, 3H), 7.37 (t, $J=7.53 \mathrm{~Hz}, 2 \mathrm{H}), 7.28-7.32$ (m, 1H), 7.09 (br. s., 1H), 6.96 (d, $J=15.81$ Hz, 1H), 4.24-4.32 (m, 1 H), 1.90-1.98 (m, 2 H), 1.71 (br. s., 2 H), 1.54-1.62 (m, 4H).

\subsection{4. (Z)-N-(1-adamantanyl)-2-cinnamamido-3-phenylacrylamide (1505)}

This compound was prepared according to the procedure described for the synthesis of 1502 starting from oxazolone $\mathbf{3}(2 \mathrm{mmol}, 0.554 \mathrm{~g})$ and 1-aminoadamantane ( $2 \mathrm{mmol}, 0.308$ g). The product 1505 was a white solid $(0.75 \mathrm{~g}, 88 \%), \mathrm{Mp} 272{ }^{\circ} \mathrm{C} .{ }^{1} \mathrm{H}$ NMR $(600 \mathrm{MHz}$, acetone- $\left.d_{6}\right) \delta_{\mathrm{H}}$ ppm $8.86(\mathrm{~s}, 1 \mathrm{H}), 7.62-7.68(\mathrm{~m}, 3 \mathrm{H}), 7.54(\mathrm{~d}, J=7.53 \mathrm{~Hz}, 2 \mathrm{H}), 7.40$ - 7.47 (m, $3 \mathrm{H}), 7.37$ (t, J=7.53 Hz, 2 H), 7.27 - 7.32 (m, 1 H), 7.05 (s, $1 \mathrm{H}), 6.98$ (d, J=15.43 Hz, $1 \mathrm{H}), 2.17$ (m, 1H), 2.13 (br. s., $6 \mathrm{H}), 2.00$ - 2.03 (m, $1 \mathrm{H}), 1.95$ - 1.97 (m, $1 \mathrm{H}), 1.73$ (br. s., $6 \mathrm{H}), 1.57-1.59(\mathrm{~m}, 1 \mathrm{H})$.

\subsection{5. (Z)-2-[(E)-cinnamamido]-3-phenyl-N-(3-pyridyl)acrylamide (1507)}

In the reaction tube of a microwave reactor (SynthLab), oxazolone $3(2 \mathrm{mmol}, 0.554 \mathrm{~g})$ and 3-aminopyridine ( $2 \mathrm{mmol}, 0.188 \mathrm{~g}$ ) were mixed with $5 \mathrm{~mL}$ DMF. The reaction was heated to $200^{\circ} \mathrm{C}$ while stirring in a Milestone microwave reactor for $10 \mathrm{~min}$. After cooling, the mixture was added slowly to ice-cold water. The resulting solid was collected by 
filtration, washed with water and purified using silica gel chromatography (petroleum ether/ dichloromethane (DCM)/MeOH, gradient) to give $\mathbf{1 5 0 7}$ as a white solid (0.206 g, $30 \%), \mathrm{Mp}>250^{\circ} \mathrm{C}(\mathrm{dec}) .{ }^{1} \mathrm{H}$ NMR $\left(600 \mathrm{MHz}\right.$, Acetone- $\left.d_{6}\right) \delta_{\mathrm{H}} \mathrm{ppm} 9.79(1 \mathrm{H}, \mathrm{br} \mathrm{s}), 9.31$ (1H, br s), $8.91(1 \mathrm{H}, \mathrm{s}), 8.31(1 \mathrm{H}, \mathrm{dd}, J=6.52,1.13 \mathrm{~Hz}), 8.27(1 \mathrm{H}, \mathrm{d}, J=8.66 \mathrm{~Hz}), 7.69-$ $7.61(5 \mathrm{H}, \mathrm{m}), 7.48-7.39(5 \mathrm{H}, \mathrm{m}), 7.38-7.32(2 \mathrm{H}, \mathrm{m}), 7.21(1 \mathrm{H}, \mathrm{s}), 7.03(1 \mathrm{H}, \mathrm{d}, J=15.81$ Hz), LC-MS (ESI), RT = 7.4 $\mathrm{min}, \mathrm{m} / \mathrm{z} 370.2[\mathrm{M}+\mathrm{H}]^{+}$.

\subsection{6. $N-[(Z)-3-a m i n o-3-o x o-1-p h e n y l p r o p-1-e n-2-y l]-(E)-c i n n a m a m i d e ~(1508)$}

Oxazolone 3 ( $2 \mathrm{mmol}, 0.554 \mathrm{~g}$ ) was stirred in $5 \mathrm{~mL}$ solution of ammonia (2M) in ethanol for $2 \mathrm{~h}$. The product was precipitated as white powder which was filtered, washed with water several times followed by ethanol and dichloromethane. Crystallization from aqueous methanol provided a white solid of $1508 \mathrm{Mp}>250{ }^{\circ} \mathrm{C}$ (dec.) ${ }^{1} \mathrm{H}$ NMR (DMSOd6) $d_{\mathrm{H}}$ ppm 10.11 (br. s., $\left.1 \mathrm{H}\right), 7.75$ (br. s., $\left.1 \mathrm{H}\right), 7.61$ (d, $\left.J=6.78 \mathrm{~Hz}, 2 \mathrm{H}\right), 7.55$ (d, $J=$ $7.53 \mathrm{~Hz}, 2 \mathrm{H}), 7.35-7.53$ (m, 6H), 7.31 (d, J=7.15 Hz, 1H), 7.16 (br. s., $1 \mathrm{H}), 7.10$ (s, 1 $\mathrm{H}), 6.91(\mathrm{~d}, J=15.81 \mathrm{~Hz}, 1 \mathrm{H})$.

\subsection{7. (Z)-2-[(E)-cinnamamido]-N-(4-methyl-1-piperazinyl)-3-phenyl-acrylamide (1511)}

This compound was prepared according to the procedure described for the synthesis of 1502 starting from oxazolone 3 (2 mmol, $0.554 \mathrm{~g})$ and 1-amino-4-methylpiperazine (4 mmol, $0.49 \mathrm{~mL})$. The product 1511 was an off-white power, (305 mg, 39\%), Mp. $190{ }^{\circ} \mathrm{C}$; 1H NMR (600 MHz, DMSO-d6) $\delta_{\mathrm{H}} \mathrm{ppm} 9.83$ (s, 1H), $9.58(\mathrm{~s}, 1 \mathrm{H}), 7.62$ (d, J = $7.53 \mathrm{~Hz}$, 2H), $7.54-7.58(\mathrm{~m}, \mathrm{~J}=7.91 \mathrm{~Hz}, 2 \mathrm{H}), 7.52(\mathrm{~d}, \mathrm{~J}=15.81 \mathrm{~Hz}, 1 \mathrm{H}), 7.44-7.48(\mathrm{~m}, 2 \mathrm{H}), 7.39$ - $7.44(\mathrm{~m}, 3 \mathrm{H}), 7.30$ - $7.35(\mathrm{~m}, 1 \mathrm{H}), 6.91$ (d, J = $15.81 \mathrm{~Hz}, 1 \mathrm{H}), 6.75$ (br. s., 1H), 3.43 (br. s., 2H), 3.14 - 3.22 (m, 4H), 3.10 (br. s., 2H), 2.77 (br. s., 3H). 


\subsection{8. (Z)-2-[(E)-cinnamamido]-3-phenyl-N-propylacrylamide (1512)}

This compound was prepared according to the procedure described for the synthesis of 1502 starting from oxazolone 3 ( $2 \mathrm{mmol}, 0.554 \mathrm{~g})$ and $n$-propylamine ( $2 \mathrm{mmol}, 0.166 \mathrm{~mL})$.

The product 1512 was a white solid (542 mg, 81\%), Mp $207{ }^{\circ} \mathrm{C} .{ }^{1} \mathrm{H}$ NMR $(850 \mathrm{MHz}$, DMSO- $\left.d_{6}\right) \delta_{\mathrm{H}} 9.69(\mathrm{~s}, 1 \mathrm{H}), 8.12(\mathrm{t}, J=5.97 \mathrm{~Hz}, 1 \mathrm{H}), 7.62(\mathrm{~d}, J=7.78 \mathrm{~Hz}, 2 \mathrm{H}), 7.55(\mathrm{~d}, J$ $=7.78 \mathrm{~Hz}, 2 \mathrm{H}), 7.50(\mathrm{~d}, J=16.09 \mathrm{~Hz}, 1 \mathrm{H}), 7.46(\mathrm{t}, J=7.79 \mathrm{~Hz}, 2 \mathrm{H}), 7.42(\mathrm{t}, J=7.79 \mathrm{~Hz}$, $1 \mathrm{H}), 7.38(\mathrm{t}, J=7.79 \mathrm{~Hz}, 2 \mathrm{H}), 7.31(\mathrm{t}, J=7.79 \mathrm{~Hz}, 1 \mathrm{H}), 7.00(\mathrm{~s}, 1 \mathrm{H}), 6.87(\mathrm{~d}, J=16.09$ $\mathrm{Hz}, 1 \mathrm{H}), 3.12(\mathrm{q}, J=6.75 \mathrm{~Hz}, 2 \mathrm{H}), 1.49(\mathrm{dt}, J=7.27$ and $6.9 \mathrm{~Hz}, 2 \mathrm{H}), 0.88(\mathrm{t}, J=7.53 \mathrm{~Hz}$, $3 \mathrm{H}) ;{ }^{13} \mathrm{C}$ NMR $\left(214 \mathrm{MHz}, \mathrm{DMSO}-d_{6}\right) \delta 165.1,164.7,140.0,134.8,134.3,130.5,129.9$, $129.4,129.1,128.6,128.6,127.8,126.9,121.6,41.0,39.8,39.7,39.6,39.5,39.4,39.3$, 39.2, 22.3, 11.5; LC-MS (ESI), RT = $3.6 \mathrm{~min}, \mathrm{~m} / z 335.1[\mathrm{M}+\mathrm{H}]^{+}$. Anal. Calcd for $\left(\mathrm{C}_{21} \mathrm{H}_{22} \mathrm{~N}_{2} \mathrm{O}_{2}\right): \mathrm{C}, 75.42 ; \mathrm{H}, 6.63 ; \mathrm{N}, 8.38$ Found $\mathrm{C}, 75.37 ; \mathrm{H}, 6.59 ; \mathrm{N}, 8.29$.

\subsection{9. (Z)-2-[(E)-cinnamamido]-N-(3-cyanophenyl)-3-phenyl-acrylamide (1513)}

This compound was prepared according to the procedure used in the synthesis of compound 1501 starting from the oxazolone 3 ( $2 \mathrm{mmol}, 0.554 \mathrm{~g}$ ) and 3 -aminobenzonitrile (2 mmol, $0.236 \mathrm{~g})$. The product 1513 as a white solid (0.352 g, 47\%), Mp 235-237 ${ }^{\circ} \mathrm{C} .{ }^{1} \mathrm{H}$ NMR (600 MHz, DMSO- $\left.d_{6}\right) \delta_{\mathrm{H}} 10.52(1 \mathrm{H}$, br s), $10.05(1 \mathrm{H}, \mathrm{br} \mathrm{s}), 8.19(\mathrm{~s}, 1 \mathrm{H}), 8.01(1 \mathrm{H}, \mathrm{d}, J=7.78$ Hz), 7.66-7.60 (m, 4H), 7.58-7.50 (m, 3H), 7.48-7.40 (m, 5H), $7.36(\mathrm{~m}, 1 \mathrm{H}), 6.98(\mathrm{~s}, 1 \mathrm{H})$, $6.93(1 \mathrm{H}, \mathrm{d}, J=16.09 \mathrm{~Hz})$.

\subsubsection{0. (Z)-2-[(E)-cinnamamido]-N-(4-fluorophenyl)-3-phenylacrylamide (1528)}

This compound was prepared according to the procedure used in the synthesis of compound 1501 starting from the oxazolone 3 ( $2 \mathrm{mmol}, 0.554 \mathrm{~g}$ ) and 3-fluoroaniline ( $2 \mathrm{mmol}, 0.192$ $\mathrm{mL})$. The final compound 1528 was collected as a white solid $(0.471 \mathrm{~g}, 65 \%), \mathrm{Mp} 200^{\circ} \mathrm{C}$. 
${ }^{1} \mathrm{H}$ NMR (600 MHz, DMSO- $\left.d_{6}\right) \delta_{\mathrm{H}} \mathrm{ppm} 10.18(1 \mathrm{H}, \mathrm{s}), 9.92(1 \mathrm{H}, \mathrm{s}), 7.74-7.68(2 \mathrm{H}, \mathrm{m})$, $7.62(4 \mathrm{H}, \mathrm{t}, J=6.96 \mathrm{~Hz}), 7.51(1 \mathrm{H}, \mathrm{d}, J=15.81 \mathrm{~Hz}), 7.48-7.39(7 \mathrm{H}, \mathrm{m}), 7.35(1 \mathrm{H}, \mathrm{m}),$, $(2 \mathrm{H}, \mathrm{m}), 6.96(\mathrm{~s}, 1 \mathrm{H}), 6.91(1 \mathrm{H}, \mathrm{d}, J=15.81 \mathrm{~Hz})$; IR (FT-IR, $\left.\mathrm{cm}^{-1}\right): 3214.5,3059.3,2979.2$, $1647.5,1614.2,1505.4$.

\subsubsection{1. (Z)-2-[(E)-cinnamamido]-N-(2-furylmethyl)-3-phenyl-acrylamide (1530)}

This compound was prepared according to the procedure described for the synthesis of 1502 starting from oxazolone 3 ( $2 \mathrm{mmol}, 0.554 \mathrm{~g})$ and furfurylamine ( $2 \mathrm{mmol}, 0.176 \mathrm{~mL})$.

The product 1530 was an off-white solid, (0.45 g, 60\%), Mp 198-199 ${ }^{\circ} \mathrm{C} .{ }^{1} \mathrm{H}$ NMR (600 MHz, DMSO- $\left.d_{6}\right) \delta_{\mathrm{H}} 9.76(1 \mathrm{H}, \mathrm{s}), 8.62(1 \mathrm{H}, \mathrm{t}, J=5.8 \mathrm{~Hz}), 7.63(2 \mathrm{H}, \mathrm{m}), 7.55-7.60(3 \mathrm{H}$, m), $7.53(1 \mathrm{H}, \mathrm{d}, J=15.8 \mathrm{~Hz}), 7.46(2 \mathrm{H}, \mathrm{m}), 7.41(1 \mathrm{H}, \mathrm{d}, J=7.5 \mathrm{~Hz}), \& 0.39(2 \mathrm{H}, \mathrm{t}, J=$ $7.7 \mathrm{~Hz}), 7.32(1 \mathrm{H}, \mathrm{m}), 7.10(1 \mathrm{H}, \mathrm{s}), 6.88(1 \mathrm{H}, \mathrm{d}, J=15.8 \mathrm{~Hz}), 6.41(1 \mathrm{H}, \mathrm{m}), 6.32(1 \mathrm{H}, \mathrm{m})$, $4.37(2 \mathrm{H}, \mathrm{d}, J=5.65 \mathrm{~Hz})$; IR (FT-IR, $\left.\mathrm{cm}^{-1}\right): 3394.3,3065.2,2955.9,1705.5,1625.7$, 1508.2; LC-MS (ESI) RT = $3.6 \mathrm{~min}, \mathrm{~m} / z 373.1[\mathrm{M}+\mathrm{H}]^{+}$. Anal. Calcd for $\left(\mathrm{C}_{23} \mathrm{H}_{20} \mathrm{~N}_{2} \mathrm{O}_{3}\right): \mathrm{C}$, 74.18; H, 5.41; N, 7.52; Found C, 73.79; H, 5.08; N, 7.65.

\subsubsection{2. (Z)-2-[(E)-cinnamamido]-N-(2-morpholinoethyl)-3-phenyl-acrylamide (1531)}

This compound was prepared according to the procedure described for the synthesis of 1502 starting from oxazolone 3 ( $2 \mathrm{mmol}, 0.554 \mathrm{~g})$ and 2-(4-morpholinyl)ethylamine (5 mmol, $0.65 \mathrm{~mL})$. The product 1531 was an off-white solid, $(0.61 \mathrm{~g}, 75 \%), \mathrm{Mp} 169{ }^{\circ} \mathrm{C} .{ }^{1} \mathrm{H}$ NMR (600 MHz, DMSO-d6) $\delta_{\mathrm{H}} 9.74(\mathrm{~s}, 1 \mathrm{H}), 7.96$ (br s, $\left.1 \mathrm{H}\right), 7.63(\mathrm{~d}, J=7.15 \mathrm{~Hz}, 2 \mathrm{H})$, $7.56(\mathrm{~d}, J=7.53 \mathrm{~Hz}, 2 \mathrm{H}), 7.53(\mathrm{~d}, J=15.81 \mathrm{~Hz}, 1 \mathrm{H}), 7.37-7.50(\mathrm{~m}, 5 \mathrm{H}), 7.29-7.36(\mathrm{~m}$, 1H), $7.07(\mathrm{~s}, 1 \mathrm{H}), 6.88(\mathrm{~d}, J=16.19 \mathrm{~Hz}, 1 \mathrm{H}), 3.52-3.61(\mathrm{~m}, 4 \mathrm{H}), 3.25-3.32(\mathrm{~m}, 2 \mathrm{H}), 2.37$ - $2.47(\mathrm{~m}, 6 \mathrm{H})$. LC-MS (ESI) RT = $3.7 \mathrm{~min}, \mathrm{~m} / z$, $406.2[\mathrm{M}+\mathrm{H}]^{+}$. 


\subsubsection{3. (Z)-2-[(E)-cinnamamido]-N-(2-hydroxyethyl)-3-phenyl-acrylamide (1532)}

Ethanolamine (10 mmol, $0.6 \mathrm{~m}$ ) was placed in a conical flask and stirred, added Oxazolone

3 ( $2 \mathrm{mmol}, 0.554 \mathrm{~g}$ ) portion wise while stirring. Reaction was left to go to completion for two hours. The mixture was treated with ice-cooled water containing $10 \mathrm{~mL} 1 \mathrm{M} \mathrm{HCl}$ and the precipitated product was collected by filtration. Purification was carried out by crystallization in ethanol to furnish $\mathbf{1 5 3 2}$ as a white fluffy solid $(0.43 \mathrm{~g}, 63.9 \%), \mathrm{Mp} 204{ }^{\circ} \mathrm{C}$, ${ }^{1} \mathrm{H}$ NMR $\left(850 \mathrm{MHz}, \mathrm{DMSO}-d_{6}\right) \delta_{\mathrm{H}} 9.72(\mathrm{~s}, 1 \mathrm{H}), 8.06(\mathrm{t}, J=5.71 \mathrm{~Hz}, 1 \mathrm{H}), 7.62(\mathrm{~d}, J=7.79$ $\mathrm{Hz}, 2 \mathrm{H}), 7.55(\mathrm{~d}, J=7.79 \mathrm{~Hz}, 2 \mathrm{H}), 7.51(\mathrm{~d}, J=15.57 \mathrm{~Hz}, 1 \mathrm{H}), 7.49-7.44(\mathrm{~m}, 2 \mathrm{H}), 7.42(\mathrm{~d}$, $J=7.27 \mathrm{~Hz}, 1 \mathrm{H}), 7.39(\mathrm{t}, J=7.79 \mathrm{~Hz}, 2 \mathrm{H}), 7.29-7.34(\mathrm{~m}, 1 \mathrm{H}), 6.88(\mathrm{~d}, J=16.09 \mathrm{~Hz}, 1 \mathrm{H})$ $7.05(\mathrm{~s}, 1 \mathrm{H}), 4.65(\mathrm{t}, J=5.71 \mathrm{~Hz}, 1 \mathrm{H}), 3.47(\mathrm{q}, J=5.88 \mathrm{~Hz}, 2 \mathrm{H}), 3.24(\mathrm{q}, J=6.23 \mathrm{~Hz}, 2$ H). LC-MS (ESI) RT = $3.48 \mathrm{~min}, \mathrm{~m} / z 337.0[\mathrm{M}+\mathrm{H}]^{+}$.

\subsubsection{4. $N$-[(Z)-3-morpholino-3-oxo-1-phenylprop-1-en-2-yl]cinnamamide (1536)}

This compound was prepared according to the procedure described for the synthesis of 1502 starting from oxazolone 3 ( $2 \mathrm{mmol}, 0.554 \mathrm{~g}$ ) and morpholine ( $4 \mathrm{mmol}, 0.39 \mathrm{~mL})$. The product 1536 was an off-white power, (.514 g, 71\%), Mp. $185^{\circ} \mathrm{C}$; $1 \mathrm{H} \mathrm{NMR}(600 \mathrm{MHz}$, DMSO-d6) $\delta_{\mathrm{H}} 10.07(\mathrm{~s}, 1 \mathrm{H}), 7.56$ - $7.63(\mathrm{~m}, 6 \mathrm{H}), 7.40$ - $7.48(\mathrm{~m}, 6 \mathrm{H}), 7.27$ - $7.36(\mathrm{~m}, 1 \mathrm{H})$, $6.93(\mathrm{~d}, \mathrm{~J}=15.81 \mathrm{~Hz}, 1 \mathrm{H}), 6.19$ (s, 1H), 3.53 (br. s., 4H), 3.35 (br. s., 4H).

\subsubsection{5. $N-[(Z)-3-(1-p y y r r o l i d i n y l)-3-o x o-1-p h e n y l p r o p-1-e n-2-y l] c i n n a m a m i d e ~(1555)$}

This compound was prepared according to the procedure described for the synthesis of 1502 starting from oxazolone 3 ( $2 \mathrm{mmol}, 0.554 \mathrm{~g})$ and pyrrolidine $(2 \mathrm{mmol}, 0.165 \mathrm{~mL})$.

The product 1555 was a white power, $(0.580 \mathrm{~g}, 84 \%)$, Mp. $194{ }^{\circ} \mathrm{C} ;{ }^{1} \mathrm{H}$ NMR $(600 \mathrm{MHz}$, DMSO- $\left.d_{6}\right) \delta_{\mathrm{H}} 10.00(\mathrm{~s}, 1 \mathrm{H}), 7.52$ - $7.64(\mathrm{~m}, 6 \mathrm{H}), 7.37$ - $7.49(\mathrm{~m}, 6 \mathrm{H}), 7.30$ - $7.33(\mathrm{~m}, 1 \mathrm{H})$, 
$6.91(\mathrm{~d}, J=15.81 \mathrm{~Hz}, 1 \mathrm{H}), 6.32(\mathrm{~s}, 1 \mathrm{H}), 3.58(\mathrm{t}, J=6.02 \mathrm{~Hz}, 2 \mathrm{H}), 3.37(\mathrm{t}, J=6.59 \mathrm{~Hz}, 2 \mathrm{H})$, $1.82-1.87(\mathrm{~m}, 4 \mathrm{H})$.

\subsubsection{6. (Z)-N-(n-butyl)-2-[(E)-cinnamamido]-3-phenylacrylamide (1556)}

This compound was prepared according to the procedure described for the synthesis of 1502 starting from oxazolone 3 ( $2 \mathrm{mmol}, 0.554 \mathrm{~g})$ and $n$-butylamine $(2 \mathrm{mmol}, 0.176 \mathrm{~mL})$.

The product 1556 was an off-white solid, (0.45 g, 60\%), Mp 198-199 ${ }^{\circ} \mathrm{C} .{ }^{1} \mathrm{H}$ NMR (600 MHz, DMSO-d6) $\delta_{\mathrm{H}} 9.69(\mathrm{~s}, 1 \mathrm{H}), 8.10(\mathrm{t}, J=5.83 \mathrm{~Hz}, 1 \mathrm{H}), 7.62(\mathrm{~d}, J=7.15 \mathrm{~Hz}, 2 \mathrm{H}), 7.56$ $(\mathrm{d}, J=7.53 \mathrm{~Hz}, 2 \mathrm{H}), 7.51(\mathrm{~d}, J=15.81 \mathrm{~Hz}, 1 \mathrm{H}), 7.44-7.48(\mathrm{~m}, 2 \mathrm{H}), 7.36-7.44(\mathrm{~m}, 3 \mathrm{H})$, $7.31(\mathrm{t}, J=7.34 \mathrm{~Hz}, 1 \mathrm{H}), 7.01(\mathrm{~s}, 1 \mathrm{H}), 6.88(\mathrm{~d}, J=16.19 \mathrm{~Hz}, 1 \mathrm{H}), 3.17(\mathrm{q}, J=6.78 \mathrm{~Hz}$, 2H), 1.47 (quin, $J=7.25 \mathrm{~Hz}, 2 \mathrm{H}), 1.32(\mathrm{sxt}, J=7.38 \mathrm{~Hz}, 2 \mathrm{H}), 0.90(\mathrm{t}, J=7.34 \mathrm{~Hz}, 3 \mathrm{H}$ ).

\subsubsection{7. (Z)-N-(sec-butyl)-2-cinnamamido-3-phenylacrylamide (1557)}

This compound was prepared according to the procedure described for the synthesis of 1502 starting from oxazolone 3 ( $2 \mathrm{mmol}, 0.554 \mathrm{~g}$ ) and sec-butylamine ( $2 \mathrm{mmol}, 0.202 \mathrm{~mL})$.

The product 1557 was an off-white solid, $(0.51 \mathrm{~g}, 73 \%)$, Mp $229{ }^{\circ} \mathrm{C} .{ }^{1} \mathrm{H}$ NMR $(600 \mathrm{MHz}$, DMSO- $\left.d_{6}\right) \delta_{\mathrm{H}} \operatorname{ppm} 9.66(\mathrm{~s}, 1 \mathrm{H}), 7.84(\mathrm{~d}, J=8.66 \mathrm{~Hz}, 1 \mathrm{H}), 7.62(\mathrm{~d}, J=7.15 \mathrm{~Hz}, 2 \mathrm{H}), 7.56$ $(\mathrm{d}, J=7.91 \mathrm{~Hz}, 2 \mathrm{H}), 7.52(\mathrm{~d}, J=15.81 \mathrm{~Hz}, 1 \mathrm{H}), 7.49-7.41(\mathrm{~m}, 3 \mathrm{H}), 7.39$ (t, $J=7.72 \mathrm{~Hz}$, 2H), 7.34-7.28 (m, 1H), 6.94-6.86 (m, $2 \mathrm{H}), 3.81(\mathrm{dt}, J=13.93,7.34 \mathrm{~Hz}, 1 \mathrm{H}), 1.39-1.59$ $(\mathrm{m}, 2 \mathrm{H}), 1.11(\mathrm{~d}, J=6.78 \mathrm{~Hz}, 3 \mathrm{H}), 0.84-0.93(\mathrm{~m}, 3 \mathrm{H})$.

\subsubsection{8. (Z)-2-[(E)-cinnamamido]-N-ethyl-3-phenylacrylamide (1558)}

This compound was prepared according to the procedure described for the synthesis of 1502 starting from oxazolone 3 ( $2 \mathrm{mmol}, 0.554 \mathrm{~g}$ ) and ethylamine ( $1 \mathrm{~mL}$ of $40 \%$ in water).

The product 1558 was an off-white solid, $(0.39 \mathrm{~g}, 61 \%)$, Mp $190{ }^{\circ} \mathrm{C} .{ }^{1} \mathrm{H}$ NMR $(600 \mathrm{MHz}$, DMSO- $\left.d_{6}\right) \delta_{\mathrm{H}}$ ppm $1.08(\mathrm{t}, J=7.34 \mathrm{~Hz}, 3 \mathrm{H}) 3.19(\mathrm{dd}, J=7.15,6.02 \mathrm{~Hz}, 2 \mathrm{H}) 6.87(\mathrm{~d}$, 
$J=15.81 \mathrm{~Hz}, 1 \mathrm{H}) 7.02(\mathrm{~s}, 1 \mathrm{H}) 7.28-7.33(\mathrm{~m}, 1 \mathrm{H}) 7.39(\mathrm{t}, J=7.72 \mathrm{~Hz}, 2 \mathrm{H}) 7.43(\mathrm{~d}, J=7.15$

Hz, 1 H) 7.44 - 7.49 (m, 2 H) 7.51 (d, J=16.19 Hz, 1 H) 7.55 (d, J=7.53 Hz, 2 H) 7.62 (d, $J=7.15 \mathrm{~Hz}, 2 \mathrm{H}) 8.11-8.17(\mathrm{~m}, 1 \mathrm{H}), 9.68(\mathrm{~s}, 1 \mathrm{H})$.

\subsubsection{9. (Z)-2-cinnamamido- $N$-ethyl- $N$-methyl-3-phenylacrylamide (1559)}

This compound was prepared according to the procedure described for the synthesis of 1502 starting from oxazolone 3 (2 mmol, $0.554 \mathrm{~g}$ ) and $N$-ethyl- $N$-Methylamine ( $2 \mathrm{mmol}$, $0.171 \mathrm{~mL}$ ). The product 1559 was a white solid $(0.61 \mathrm{~g}, 91 \%)$, Mp $169^{\circ} \mathrm{C} .{ }^{1} \mathrm{H}$ NMR (600 MHz, DMSO- $\left.d_{6}\right) \delta_{\mathrm{H}}$ ppm 10.01 (br. s., $\left.1 \mathrm{H}\right), 7.61$ (d, J=7.15 Hz, $\left.2 \mathrm{H}\right), 7.52-7.59(\mathrm{~m}, 3 \mathrm{H})$, 7.37 - 7.49 (m, 5 H), 7.27 - 7.34 (m, 1 H), 6.94 (d, J=15.81 Hz, 1 H), 6.09 - 6.20 (s, 1 H), $3.08(\mathrm{~s}, 3 \mathrm{H}), 2.85(\mathrm{q}, J=7.1 \mathrm{~Hz}, 2 \mathrm{H}), 1.12(\mathrm{t}, J=6.9 \mathrm{~Hz}, 3 \mathrm{H})$.

\subsubsection{Ethyl (Z)-2-cinnamamido-3-phenylacrylate (15EE)}

The oxazolone 3 ( $2 \mathrm{mmol}, 0.554 \mathrm{~g}$ ) was heated under reflux in absolute ethanol in presence of $5 \mathrm{mg}$ of 4-dimethylaminopyridine (DMAP) for 3 hours. The solvent was removed by vacuum evaporation and residue was partitioned between dichloromethane and $1 \mathrm{M} \mathrm{HCl}$. The organic layer was washed with water then brine, dried with sodium sulfated and evaporated under vacuum to give the product $15 \mathrm{EE}$ as an off-white solid $(0.51 \mathrm{~g}, 79 \%)$, Mp $153{ }^{\circ} \mathrm{C} .{ }^{1} \mathrm{H}$ NMR $\left(600 \mathrm{MHz}, \mathrm{CDCl}_{3}\right) \delta_{\mathrm{H}} 8.97$ (br. s., $\left.1 \mathrm{H}\right), 7.62$ - $7.69(\mathrm{~m}, 5 \mathrm{H}), 7.34$ $7.50(\mathrm{~m}, 6 \mathrm{H}), 7.30(\mathrm{~s}, 1 \mathrm{H}), 6.99(\mathrm{~d}, J=15.81 \mathrm{~Hz}, 1 \mathrm{H}), 4.27(\mathrm{q}, J=7.03 \mathrm{~Hz}, 2 \mathrm{H}), 1.31(\mathrm{t}$, $J=7.15 \mathrm{~Hz}, 3 \mathrm{H})$.

\subsubsection{1. (Z)-N-(n-propyl)- 2-(benzoylamino)-3-phenylacrylamide (1612)}

This compound was prepared according to the procedure described for the synthesis of 1502 starting from 4-benzylidene-2-phenyloxazol-5(4H)-one $(0.25 \mathrm{~g}, 1 \mathrm{mmol})$ and $n$ propylamine $(0.16 \mathrm{~mL}, 2 \mathrm{mmol})$. The product 1612 was an off-white solid, $(0.27 \mathrm{~g}, 81 \%)$, 
Mp $169{ }^{\circ} \mathrm{C} .{ }^{1} \mathrm{H}$ NMR $\left(850 \mathrm{MHz}, \mathrm{DMSO}-d_{6}\right) \delta_{\mathrm{H}} 10.17$ (br s, $\left.1 \mathrm{H}\right), 8.32$ (br s, $\left.1 \mathrm{H}\right), 8.00(\mathrm{~d}$, $J=7.27 \mathrm{~Hz}, 1 \mathrm{H}), 7.88-7.86(\mathrm{~m}, 1 \mathrm{H}), 7.61-7.55(\mathrm{~m}, 1 \mathrm{H}), 7.53-7.47(\mathrm{~m}, 1 \mathrm{H}), 7.40(\mathrm{~d}, J=$ $8.30 \mathrm{~Hz}, 1 \mathrm{H}), 7.20-7.28(\mathrm{~m}, 2 \mathrm{H}), 3.11(\mathrm{~m}, J=6.75 \mathrm{~Hz}, 2 \mathrm{H}), 1.47(\mathrm{~m}, 1 \mathrm{H}), 0.86(\mathrm{t}, J=7.27$ Hz, 3H). LC-MS (ESI) RT = $4.52 \mathrm{~min}, \mathrm{~m} / z 309.0[\mathrm{M}+\mathrm{H}]+$.

\subsubsection{2. (2Z,4E)-2-cinnamamido-5-phenyl-N-propylpenta-2,4-dienamide (1712)[21]}

This compound was prepared according to the procedure described for the synthesis of 1502 starting from (Z)-4-[(E)-3-(phenylallylidene)-2-(E)-styryl]oxazol-5(4H)-one (0.3 g, $1 \mathrm{mmol})$ and n-propylamine $(0.16 \mathrm{~mL}, 2 \mathrm{mmol})$. The product 1712 was a light yellow solid, (0.314 g, 87\%), Mp $186{ }^{\circ} \mathrm{C} .{ }^{1} \mathrm{H}$ NMR $\left(850 \mathrm{MHz}, \mathrm{DMSO}-\mathrm{d}_{6}\right) \delta_{\mathrm{H}} 9.69(\mathrm{~s}, 1 \mathrm{H}), 8.02$ (t, J = $5.71 \mathrm{~Hz}, 1 \mathrm{H}), 7.64(\mathrm{~d}, \mathrm{~J}=7.27 \mathrm{~Hz}, 2 \mathrm{H}), 7.55-7.52(\mathrm{~m}, 3 \mathrm{H}), 7.47$ - $7.45(\mathrm{~m}, 2 \mathrm{H}), 7.42-7.40$ (m, 1H), 7.38-7.35 (m, 2H), 7.31-7.28 (t, J = 7.26 Hz, 1H), 7.05-7.00 (dd, 1H, J = 15.8 and $10.7 \mathrm{~Hz}), 6.92-6.87(\mathrm{~m}, 2 \mathrm{H}), 6.73(\mathrm{~d}, \mathrm{~J}=10.90 \mathrm{~Hz}, 1 \mathrm{H}), 3.12-3.08(\mathrm{q}, \mathrm{J}=8.6 \mathrm{~Hz}, 2 \mathrm{H})$, 1.50-1.44 (m, 2H), 0.94 (t, J = 7.53 Hz, 1H), 0.87 (t, J = 7.27 Hz, 3 H), LC-MS (ESI) RT $=5.25 \mathrm{~min}, \mathrm{~m} / \mathrm{z} 361.1[\mathrm{M}+\mathrm{H}]+($ The compound contained $24.2 \%$ of E-isomer $(2 \mathrm{E}, 4 \mathrm{E})-2-$ cinnamamido-5-phenyl-N-propylpenta-2,4-dienamide according to LC-MS (UV) determination. All data are reported for the $\mathrm{Z}$ isomer.

\subsubsection{3. (Z)-2-[(E)-3-(4-chlorophenyl)acrylamido]-3-phenyl-N-propylacrylamide (1812)}

This compound was prepared according to the procedure described for the synthesis of 1502 starting from 4-[(Z)-benzylidene]-2-[(E)-4-chlorostyryl $]$ oxazol-5(4H)-one $(0.310 \mathrm{~g}$, $1 \mathrm{mmol})$ and $n$-propylamine $(0.16 \mathrm{~mL}, 2 \mathrm{mmol})$. The product 1812 was a white solid (325 mg, 88\%), Mp 190-191 ${ }^{\circ} \mathrm{C} . \mathrm{IR}\left(\mathrm{KBr}, v_{\max } \mathrm{cm}^{-1}\right) 3281,2958,1651,1611 ;{ }^{1} \mathrm{H}$ NMR (850 MHz, DMSO-d $\left.d_{6}\right) \delta_{\mathrm{H}} 9.71$ (br. s., $\left.1 \mathrm{H}\right), 8.12$ (t, $\left.J=5.71 \mathrm{~Hz}, 1 \mathrm{H}\right), 7.64$ (d, $\left.J=8.30 \mathrm{~Hz}, 2 \mathrm{H}\right)$, $7.46-7.58(\mathrm{~m}, 4 \mathrm{H}), 7.38(\mathrm{t}, J=7.79 \mathrm{~Hz}, 2 \mathrm{H}), 7.31(\mathrm{t}, J=7.79 \mathrm{~Hz}, 1 \mathrm{H}), 7.00(\mathrm{~s}, 1 \mathrm{H}), 6.87$ 
$(\mathrm{d}, J=16.09 \mathrm{~Hz}, 1 \mathrm{H}), 3.12(\mathrm{q}, J=6.75 \mathrm{~Hz}, 2 \mathrm{H}), 1.49(\mathrm{sxt}, J=7.27 \mathrm{~Hz}, 2 \mathrm{H}), 0.88(\mathrm{t}, J=$

$7.27 \mathrm{~Hz}, 3 \mathrm{H}) ;{ }^{13} \mathrm{C}$ NMR $\left(214 \mathrm{MHz}, \mathrm{DMSO}-d_{6}\right) \delta_{\mathrm{C}} 165.1,164.5,138.7,134.3,133.8,130.4$, $129.5,129.4,129.2,128.7,128.6,127.0,122.4,41.1,39.8,39.7,39.6,39.5,39.4,39.3$, 39.2, 22.4, 11.5; LC/MS (ESI), RT = $4.8 \mathrm{~min}, \mathrm{~m} / \mathrm{z} 369(\mathrm{M}+1), 370(\mathrm{M}+2)$.

\subsubsection{4. (Z)-2-[(E)-3-(4-methoxyphenyl)acrylamido]-3-phenyl-N-propylacrylamide} (1912)

This compound was prepared according to the procedure described for the synthesis of 1502 starting from 4-[(Z)-benzylidene]-2-[(E)-4-methoxystyryl]oxazol-5(4H)-one $(0.305$ $\mathrm{g}, 1 \mathrm{mmol})$ and $n$-propylamine $(0.16 \mathrm{~mL}, 2 \mathrm{mmol})$. The product 1912 was a white solid (303 mg, 83\%), Mp 184-185 ${ }^{\circ} \mathrm{C}$. IR (KBr, $\left.v_{\max } \mathrm{cm}^{-1}\right) 3229,2964,1650,1625 ;{ }^{1} \mathrm{H}$ NMR $\left(600 \mathrm{MHz}, \mathrm{DMSO}-d_{6}\right) \delta_{\mathrm{H}} 9.62(\mathrm{~s}, 1 \mathrm{H}), 8.12(\mathrm{t}, J=5.65 \mathrm{~Hz}, 1 \mathrm{H}), 7.51-7.62(\mathrm{~m}, 4 \mathrm{H}), 7.45$ $(\mathrm{d}, J=15.43 \mathrm{~Hz}, 1 \mathrm{H}), 7.38(\mathrm{t}, J=7.72 \mathrm{~Hz}, 2 \mathrm{H}), 7.31(\mathrm{t}, J=7.79 \mathrm{~Hz}, 1 \mathrm{H}), 7.02(\mathrm{~d}, J=8.66$ Hz, 2H), 6.97 (s, 1H), 6.72 (d, $J=15.81 \mathrm{~Hz}, 1 \mathrm{H}), 3.81$ (s, 3H), 3.11 (q, J = 6.40 Hz, 2H), $1.48(\mathrm{sxt}, J=7.30 \mathrm{~Hz}, 2 \mathrm{H}), 0.87(\mathrm{t}, J=7.34 \mathrm{~Hz}, 3 \mathrm{H}) ;{ }^{13} \mathrm{C}$ NMR $\left(214 \mathrm{MHz}\right.$, DMSO- $\left.d_{6}\right) \delta_{\mathrm{C}}$ $165.1,164.9,160.6,139.7,134.4,130.7,129.4,129.3,128.6,128.5,127.3,126.6,119.0$, 114.5, 55.4, 41.0, 39.8, 39.7, 39.6, 39.5, 39.4, 39.3, 39.2, 22.4, 11.5; LC/MS (ESI), RT = $3.5 \mathrm{~min}, \mathrm{~m} / \mathrm{z} 365(\mathrm{M}+1)$.

\subsubsection{5. (Z)-3-phenyl-N-propyl-2-[(E)-3-(p-tolyl)acrylamido]acrylamide (2012)}

This compound was prepared according to the procedure described for the synthesis of 1502 starting from 4-[(Z)-benzylidene]-2-[(E)-4-methylstyryl]oxazol-5(4H)-one $(0.289 \mathrm{~g}$, $1 \mathrm{mmol})$ and $n$-propylamine $(0.16 \mathrm{~mL}, 2 \mathrm{mmol})$. The product 2012 was an off-white solid (321 mg, 92\%), Mp 175-176 ${ }^{\circ} \mathrm{C}$. IR (KBr, $\left.v_{\max } \mathrm{cm}^{-1}\right) 3296,3172,2967,1646,1610 ;{ }^{1} \mathrm{H}$

NMR (850 MHz, DMSO- $\left.d_{6}\right) \delta_{\mathrm{H}} 9.65$ (br. s., $\left.1 \mathrm{H}\right), 8.11(\mathrm{t}, J=5.45 \mathrm{~Hz}, 1 \mathrm{H}), 7.48-7.57$ (m, 
$4 \mathrm{H}), 7.46(\mathrm{~d}, J=15.57 \mathrm{~Hz}, 1 \mathrm{H}), 7.37-7.40(\mathrm{~m}, 2 \mathrm{H}), 7.27-7.34(\mathrm{~m}, 2 \mathrm{H}), 7.26(\mathrm{~d}, J=7.78$ Hz, 1H), $6.98-7.01(\mathrm{~m}, 1 \mathrm{H}), 6.82(\mathrm{~d}, J=15.57 \mathrm{~Hz}, 1 \mathrm{H}), 3.09-3.13(\mathrm{~m}, 2 \mathrm{H}), 1.48(\mathrm{td}, J=$ 7.20, $14.14 \mathrm{~Hz}, 2 \mathrm{H}), 0.87(\mathrm{t}, J=7.27 \mathrm{~Hz}, 3 \mathrm{H}) ;{ }^{13} \mathrm{C}$ NMR $\left(214 \mathrm{MHz}, \mathrm{DMSO}-d_{6}\right) \delta_{\mathrm{C}} 165.2$, $164.9,140.1,139.8,134.4,132.1,130.6,129.8,129.4,128.7,127.9,127.5,126.9,120.6$, 41.1, 39.8, 39.7, 39.6, 39.5, 39.4, 39.3, 39.2, 22.5, 21.1, 11.6; LC/MS (ESI), RT = $4.3 \mathrm{~min}$, $\mathrm{m} / \mathrm{z} 349(\mathrm{M}+1)$.

\subsubsection{6. (Z)-3-phenyl-N-propyl-2-[(E)-3-(thien-2-yl)acrylamido]acrylamide (2112)}

This compound was prepared according to the procedure described for the synthesis of 1502 starting from 4-[(Z)-benzylidene]-2-[(E)-2-(thien-3-yl)vinyl]oxazol-5(4H)-one (0.281 g, $1 \mathrm{mmol})$ and $n$-propylamine $(0.16 \mathrm{~mL}, 2 \mathrm{mmol})$. The product 2112 was an offwhite solid (263 mg, 77\%), Mp 195-196 ${ }^{\circ} \mathrm{C}$. IR ( $\left.\mathrm{KBr}, v_{\max } \mathrm{cm}^{-1}\right)$ 3296, 3172, 2967, 1646, 1610; ${ }^{1} \mathrm{H}$ NMR $\left(850 \mathrm{MHz}, \mathrm{DMSO}-d_{6}\right) \delta_{\mathrm{H}} 9.65(\mathrm{~s}, 1 \mathrm{H}), 8.10(\mathrm{t}, J=5.71 \mathrm{~Hz}, 1 \mathrm{H}), 7.61-$ $7.68(\mathrm{~m}, 2 \mathrm{H}), 7.53(\mathrm{~d}, J=7.79 \mathrm{~Hz}, 2 \mathrm{H}), 7.43(\mathrm{~d}, J=3.11 \mathrm{~Hz}, 1 \mathrm{H}), 7.39(\mathrm{t}, J=7.79 \mathrm{~Hz}$, 2H), $7.31(\mathrm{t}, J=7.79 \mathrm{~Hz}, 1 \mathrm{H}), 7.14(\mathrm{dd}, J=3.37,4.93 \mathrm{~Hz}, 1 \mathrm{H}), 6.99(\mathrm{~s}, 1 \mathrm{H}), 6.62(\mathrm{~d}, J=$ $15.57 \mathrm{~Hz}, 1 \mathrm{H}), 3.11(\mathrm{q}, J=6.75 \mathrm{~Hz}, 2 \mathrm{H}), 1.48(\mathrm{sxt}, J=7.27 \mathrm{~Hz}, 2 \mathrm{H}), 0.87(\mathrm{t}, J=7.53 \mathrm{~Hz}$, $3 \mathrm{H}) ;{ }^{13} \mathrm{C}$ NMR $\left(214 \mathrm{MHz}\right.$, DMSO- $\left.d_{6}\right) \delta_{\mathrm{C}} 165.0,164.4,139.8,134.3,133.0,131.3,130.5$, $129.3,128.6,128.6,128.5,128.5,126.9,120.3,41.0,39.8,39.7,39.6,39.5,39.4,39.3$, 39.2, 22.4, 11.5; LC/MS (ESI), RT = $3.4 \mathrm{~min}, \mathrm{~m} / \mathrm{z} 341(\mathrm{M}+1)$.

\subsubsection{7. (Z)-2-cinnamamido-3-(4-fluorophenyl)- $\mathrm{N}$-propylacrylamide (2212)}

This compound was prepared according to the procedure described for the synthesis of 1502 starting from 4-[(Z)-4-fluorobenzylidene]-2-[(E)-styryl]oxazol-5(4H)- $(0.293 \mathrm{~g}, 1$ $\mathrm{mmol})$ and $n$-propylamine $(0.16 \mathrm{~mL}, 2 \mathrm{mmol})$. The product 2212 was an off-white solid (290 mg, 82\%), Mp 192-193 ${ }^{\circ} \mathrm{C}$. IR (KBr, $\left.v_{\max } \mathrm{cm}^{-1}\right) 3360,3026,2950,1650,1610 ;{ }^{1} \mathrm{H}$ 
NMR (DMSO- $\left.d_{6}\right) \delta_{\mathrm{H}} \mathrm{ppm} 9.68(\mathrm{~s}, 1 \mathrm{H}), 8.12(\mathrm{~s}, 1 \mathrm{H}), 7.56$ - 7.67 (m, $\left.4 \mathrm{H}\right), 7.50$ (d, $J=16.09 \mathrm{~Hz}, 1 \mathrm{H}), 7.44-7.47(\mathrm{~m}, 2 \mathrm{H}), 7.42(\mathrm{~d}, J=7.78 \mathrm{~Hz}, 1 \mathrm{H}), 7.23(\mathrm{t}, J=8.82 \mathrm{~Hz}, 2$ H), $7.01(\mathrm{~s}, 1 \mathrm{H}), 6.86(\mathrm{~d}, J=16.09 \mathrm{~Hz}, 1 \mathrm{H}), 3.12(\mathrm{q}, J=6.75 \mathrm{~Hz}, 2 \mathrm{H}), 1.45-1.52(\mathrm{~m}, 2$ H), 0.87 (t, J=7.53 Hz, $3 \mathrm{H})$; LC/MS (ESI), RT = $3.9 \mathrm{~min}, \mathrm{~m} / \mathrm{z} 353(\mathrm{M}+1)$.

\subsubsection{8. (Z)-2-[(E)-3-(4-chlorophenyl)acrylamido]-3-(4-fluorophenyl)-N-} propylacrylamide (2312)

This compound was prepared according to the procedure described for the synthesis of 1502 starting from 2-[(E)-4-chlorostyryl]-4-[(Z)-4-fluorobenzylidene]oxazol-5(4H)-one $(0.327 \mathrm{~g}, 1 \mathrm{mmol})$ and $n$-propylamine $(0.16 \mathrm{~mL}, 2 \mathrm{mmol})$. The product 2312 was an offwhite solid (341 mg, 88\%), Mp 187-188 ${ }^{\circ} \mathrm{C}$. IR (KBr, $\left.v_{\max } \mathrm{cm}^{-1}\right)$ 3360, 3002, 2949, 1650, 1610; ${ }^{1} \mathrm{H}$ NMR $\left(850 \mathrm{MHz}, \mathrm{DMSO}-d_{6}\right) \delta_{\mathrm{H}} 9.69(\mathrm{~s}, 1 \mathrm{H}), 8.12(\mathrm{t}, J=5.71 \mathrm{~Hz}, 1 \mathrm{H}), 7.64(\mathrm{~d}$, $J=8.30 \mathrm{~Hz}, 2 \mathrm{H}), 7.60(\mathrm{dd}, J=5.71,8.82 \mathrm{~Hz}, 2 \mathrm{H}), 7.46-7.55(\mathrm{~m}, 3 \mathrm{H}), 7.20-7.26(\mathrm{~m}$, 2H), $7.01(\mathrm{~s}, 1 \mathrm{H}), 6.85(\mathrm{~d}, J=16.09 \mathrm{~Hz}, 1 \mathrm{H}), 3.11(\mathrm{q}, J=6.40 \mathrm{~Hz}, 2 \mathrm{H}), 1.48(\mathrm{sxt}, J=7.27$ $\mathrm{Hz}, 2 \mathrm{H}), 0.87(\mathrm{t}, J=7.27 \mathrm{~Hz}, 3 \mathrm{H}) ;{ }^{13} \mathrm{C} \mathrm{NMR}\left(214 \mathrm{MHz}, \mathrm{DMSO}-d_{6}\right) \delta_{\mathrm{C}} 164.9,164.4,138.7$, $134.3,133.7,131.5,130.9,130.1,129.5,129.2,125.9,122.4,115.6,115.5,41.0,39.8,39.7$, 39.6, 39.5, 39.4, 39.3, 39.2, 22.4, 11.5; LC/MS (ESI), RT = 5.1 min, m/z $387(\mathrm{M}+1), 388$ $(\mathrm{M}+2)$.

\subsubsection{9. (Z)-3-(4-fluorophenyl)-2-[(E)-3-(4-methoxyphenyl)acrylamido]-N-}

\section{propylacrylamide (2412)}

This compound was prepared according to the procedure described for the synthesis of 1502 starting from 4-[(Z)-4-fluorobenzylidene)]-2-[(E)-4-methoxystyryl]oxazol-5(4H)one $(0.323 \mathrm{~g}, 1 \mathrm{mmol})$ and $n$-propylamine $(0.16 \mathrm{~mL}, 2 \mathrm{mmol})$. The product 2412 was a white solid (355 mg, 93\%), Mp 199-200 ${ }^{\circ} \mathrm{C}$. IR (KBr, $v_{\max } \mathrm{cm}^{-1}$ ) 3285, 2961, 1649, 1608; 
${ }^{1} \mathrm{H}$ NMR (600 MHz, DMSO-d $) \delta \mathrm{H} 9.61(\mathrm{~s}, 1 \mathrm{H}), 8.12(\mathrm{t}, J=5.65 \mathrm{~Hz}, 1 \mathrm{H}), 7.56-7.61(\mathrm{~m}$, 4H), $7.45(\mathrm{~d}, J=15.81 \mathrm{~Hz}, 1 \mathrm{H}), 7.20-7.26(\mathrm{~m}, 2 \mathrm{H}), 7.02(\mathrm{~d}, J=8.66 \mathrm{~Hz}, 2 \mathrm{H}), 6.98(\mathrm{~s}$, $1 \mathrm{H}), 6.71(\mathrm{~d}, J=15.81 \mathrm{~Hz}, 1 \mathrm{H}), 3.81(\mathrm{~s}, 3 \mathrm{H}), 3.11(\mathrm{q}, J=6.65 \mathrm{~Hz}, 2 \mathrm{H}), 1.48(\mathrm{sxt}, J=7.30$ $\mathrm{Hz}, 2 \mathrm{H}), 0.87(\mathrm{t}, J=7.53 \mathrm{~Hz}, 3 \mathrm{H}) ;{ }^{13} \mathrm{C}$ NMR $\left(214 \mathrm{MHz}, \mathrm{DMSO}-d_{6}\right) \delta_{\mathrm{C}} 165.1,164.9,160.7$, $139.9,131.5,131.0,130.4,129.5,127.3,125.6,119.0,115.6,115.5,114.6,55.4,41.0,39.8$, 39.7, 39.6, 39.5, 39.4, 39.3 39.2, 22.4, 11.5; LC/MS (ESI), RT = 3.8 min, m/z $383(\mathrm{M}+1)$. 4.1.30. (Z)-3-(4-fluorophenyl)-N-propyl-2-[(E)-3-(p-tolyl)acrylamido]acrylamide (2512) This compound was prepared according to the procedure described for the synthesis of 1502 starting from 4-[(Z)-4-fluorobenzylidene]-2-[(E)-4-methylstyryl]oxazol-5(4H)-one $(0.307 \mathrm{~g}, 1 \mathrm{mmol})$ and $n$-propylamine $(0.16 \mathrm{~mL}, 2 \mathrm{mmol})$. The product 2512 was an offwhite solid (289 mg, 79\%), Mp 164-165 ${ }^{\circ} \mathrm{C}$. IR ( $\left.\mathrm{KBr}, v_{\max } \mathrm{cm}^{-1}\right)$ 3302, 3208, 2970, 1649, $1640 ;{ }^{1} \mathrm{H}$ NMR (850 MHz, DMSO- $\left.d_{6}\right) \delta_{\mathrm{H}} 9.64(\mathrm{~s}, 1 \mathrm{H}), 8.11(\mathrm{t}, J=5.71 \mathrm{~Hz}, 1 \mathrm{H}), 7.60(\mathrm{dd}$, $J=5.71,8.82 \mathrm{~Hz}, 2 \mathrm{H}), 7.50(\mathrm{~d}, J=8.30 \mathrm{~Hz}, 2 \mathrm{H}), 7.46(\mathrm{~d}, J=16.09 \mathrm{~Hz}, 1 \mathrm{H}), 7.26 \mathrm{~d}, J=$ $8.30 \mathrm{~Hz}, 2 \mathrm{H}), 7.20-7.25(\mathrm{~m}, 2 \mathrm{H}), 7.00(\mathrm{~s}, 1 \mathrm{H}), 6.81(\mathrm{~d}, J=15.57 \mathrm{~Hz}, 1 \mathrm{H}), 3.12(\mathrm{q}, J=$ $6.75 \mathrm{~Hz}, 2 \mathrm{H}), 2.35(\mathrm{~s}, 3 \mathrm{H}), 1.48(\mathrm{sxt}, J=7.27 \mathrm{~Hz}, 2 \mathrm{H}), 0.87(\mathrm{t}, J=7.27 \mathrm{~Hz}, 3 \mathrm{H}) ;{ }^{13} \mathrm{C} \mathrm{NMR}$ $\left(214 \mathrm{MHz}, \mathrm{DMSO}-d_{6}\right) \delta_{\mathrm{C}} 165.0,164.8,140.0,139.7,132.0,131.5,131.0,130.3,129.7$, $127.8,125.7,120.5,115.6,115.5,41.0,39.8,39.7,39.6,39.5,39.4,39.3,39.2,22.4,21.1$, 11.5; LC/MS (ESI), RT = $3.7 \mathrm{~min}, \mathrm{~m} / \mathrm{z} 367(\mathrm{M}+1)$.

\subsubsection{1. (Z)-3-(4-fluorophenyl)-N-propyl-2-[(E)-3-(thien-2-yl)acrylamido]acrylamide} (2612)

This compound was prepared according to the procedure described for the synthesis of 1502 starting from 4-([(Z)-4-fluorobenzylidene]-2-[(E)-2-(thien-3-yl)vinyl]oxazol-5(4H)one $(0.299 \mathrm{~g}, 1 \mathrm{mmol})$ and $n$-propylamine $(0.16 \mathrm{~mL}, 2 \mathrm{mmol})$. The product 2612 was a 
yellow solid (279 mg, 78\%), Mp 142-143 ${ }^{\circ} \mathrm{C}$. IR (KBr, $\left.v_{\max } \mathrm{cm}^{-1}\right) 3302,3143,2961,1650$, 1610; ${ }^{1} \mathrm{H}$ NMR $\left(850 \mathrm{MHz}, \mathrm{DMSO}-d_{6}\right) \delta \mathrm{ppm} 9.63(\mathrm{~s}, 1 \mathrm{H}) 8.11(\mathrm{t}, J=5.71 \mathrm{~Hz}, 1 \mathrm{H}) 7.61$ $7.68(\mathrm{~m}, 2 \mathrm{H}) 7.58(\mathrm{dd}, J=8.04,5.97 \mathrm{~Hz}, 2 \mathrm{H}) 7.43(\mathrm{~d}, J=3.11 \mathrm{~Hz}, 1 \mathrm{H}) 7.23(\mathrm{t}, J=8.56 \mathrm{~Hz}$, 2 H) $7.11-7.16(\mathrm{~m}, 1 \mathrm{H}) 7.00(\mathrm{~s}, 1 \mathrm{H}) 6.60(\mathrm{~d}, J=15.57 \mathrm{~Hz}, 1 \mathrm{H}) 3.11(\mathrm{q}, J=6.40 \mathrm{~Hz}, 2 \mathrm{H})$ $1.48(\mathrm{sxt}, J=7.27 \mathrm{~Hz}, 2 \mathrm{H}) 0.87(\mathrm{t}, J=7.53 \mathrm{~Hz}, 3 \mathrm{H}) ;{ }^{13} \mathrm{C}$ NMR $\left(214 \mathrm{MHz}, \mathrm{DMSO}-d_{6}\right) \delta_{\mathrm{C}}$ $165.0,164.4,139.8,133.1,131.6,131.5,131.4,130.9,130.2,128.6,128.5,126.3,125.9$, 120.3, 41.0, 39.8, 39.7, 39.6, 39.5, 39.4, 39.3, 39.2, 22.4, 11.5; LC/MS (ESI), RT = 3.5 $\min , \mathrm{m} / \mathrm{z} 359(\mathrm{M}+1)$.

\subsubsection{2. (Z)-2-cinnamamido-3-[4-(dimethylamino)phenyl]-N-propylacrylamide (2712)}

This compound was prepared according to the procedure described for the synthesis of 1502 starting from 4-[(Z)-4-(dimethylamino)benzylidene]-2-[(E)-styryl]oxazol-5(4H)-one $(0.318 \mathrm{~g}, 1 \mathrm{mmol})$ and $n$-propylamine $(0.16 \mathrm{~mL}, 2 \mathrm{mmol})$. The product 2712 was an offwhite solid (328 mg, 87\%), Mp 207-208 ${ }^{\circ} \mathrm{C}$. IR (KBr, $v_{\max } \mathrm{cm}^{-1}$ ) 3087, 2933, 1659; ${ }^{1} \mathrm{H}$ NMR (600 MHz, DMSO-d6) $\delta_{\mathrm{H}} 9.51(\mathrm{~s}, 1 \mathrm{H}), 7.91(\mathrm{t}, J=5.84 \mathrm{~Hz}, 1 \mathrm{H}), 7.63(\mathrm{~d}, J=7.15$ $\mathrm{Hz}, 2 \mathrm{H}), 7.45-7.52(\mathrm{~m}, 3 \mathrm{H}), 7.40-7.44(\mathrm{~m}, 3 \mathrm{H}), 7.04(\mathrm{~s}, 1 \mathrm{H}), 6.90(\mathrm{~d}, J=15.81 \mathrm{~Hz}, 1 \mathrm{H})$, $6.70(\mathrm{~d}, J=9.03 \mathrm{~Hz}, 2 \mathrm{H}), 3.11(\mathrm{q}, J=6.75 \mathrm{~Hz}, 2 \mathrm{H}), 2.92(\mathrm{~s}, 6 \mathrm{H}), 1.46(\mathrm{sxt}, J=7.23 \mathrm{~Hz}$, $2 \mathrm{H}), 0.86(\mathrm{t}, J=7.34 \mathrm{~Hz}, 3 \mathrm{H}) ;{ }^{13} \mathrm{C} \mathrm{NMR}\left(214 \mathrm{MHz}, \mathrm{DMSO}-d_{6}\right) \delta_{\mathrm{C}} 169.6,168.0,142.5$, $141.1,135.8,134.7,131.2,129.3,129.0,128.7,128.1,127.5,126.3,111.0,41.6,40.7,39.8$, 39.7, 39.6, 39.5, 39.4, 39.3, 39.2, 22.3, 11.4; LC/MS (ESI), RT = 3.8 min, m/z $378(\mathrm{M}+1)$.

\subsubsection{3. (Z)-2-[(E)-3-(4-chlorophenyl)acrylamido]-3-[4-(dimethylamino)phenyl]-N-} propylacrylamide (2812)

This compound was prepared according to the procedure described for the synthesis of 1502 starting from 2-[(E)-4-chlorostyryl]-4-[(Z)-4-(dimethylamino)benzylidene $]$ oxazol- 
5(4H)-one $(0.353 \mathrm{~g}, 1 \mathrm{mmol})$ and $n$-propylamine $(0.16 \mathrm{~mL}, 2 \mathrm{mmol})$. The product 2812 was a yellow solid (371 mg, 90\%), Mp 243-244 ${ }^{\circ} \mathrm{C}$. IR $\left(\mathrm{KBr}, v_{\max } \mathrm{cm}^{-1}\right)$ 3067, 2912, 1648, 1609; ${ }^{1} \mathrm{H}$ NMR (600 MHz, DMSO- $\left.d_{6}\right) \delta_{\mathrm{H}} 9.53(\mathrm{~s}, 1 \mathrm{H}), 7.92(\mathrm{t}, J=6.02 \mathrm{~Hz}, 1 \mathrm{H}), 7.65$ (d, $J=8.66 \mathrm{~Hz}, 2 \mathrm{H}), 7.53(\mathrm{~d}, J=8.28 \mathrm{~Hz}, 2 \mathrm{H}), 7.50(\mathrm{~d}, J=15.81 \mathrm{~Hz}, 1 \mathrm{H}), 7.42(\mathrm{~d}, J=9.03$ Hz, 2H), $7.04(\mathrm{~s}, 1 \mathrm{H}), 6.90(\mathrm{~d}, J=15.81 \mathrm{~Hz}, 1 \mathrm{H}), 6.69(\mathrm{~d}, J=9.03 \mathrm{~Hz}, 2 \mathrm{H}), 3.10(\mathrm{q}, J=$ $6.40 \mathrm{~Hz}, 2 \mathrm{H}), 2.93$ (s, 6H), $1.46(\mathrm{sxt}, J=7.23 \mathrm{~Hz}, 2 \mathrm{H}), 0.86(\mathrm{t}, J=7.34 \mathrm{~Hz}, 3 \mathrm{H}) ;{ }^{13} \mathrm{C} \mathrm{NMR}$ (214 MHz, DMSO-d $d_{6} \delta_{\mathrm{C}} 166.5,163.1,140.1,137.9,134.6,133.4,131.2,129.4,129.3$, $128.8,128.6,128.2,127.8,127.5,41.3,40.5,39.8,39.7,39.6,39.5,39.4,39.3,39.2,22.4$, 11.4; LC/MS (ESI), RT = $5.9 \mathrm{~min}, \mathrm{~m} / \mathrm{z} 412(\mathrm{M}+1), 413(\mathrm{M}+2)$.

\subsubsection{4. (Z)-3-[4-(dimethylamino)phenyl]-2-[(E)-3-(4-methoxyphenyl)acrylamido]-N-}

\section{propylacrylamide (2912)}

This compound was prepared according to the procedure described for the synthesis of 1502 starting from 4-[(Z)-4-(dimethylamino)benzylidene]-2-[(E)-4-methoxystyryl]oxazol-5(4H)-one $(0.348 \mathrm{~g}, 1 \mathrm{mmol})$ and $n$-propylamine $(0.16 \mathrm{~mL}, 2 \mathrm{mmol})$. The product 2912 was a yellow solid (346 mg, 85\%), Mp 236-237 ${ }^{\circ} \mathrm{C}$. IR ( $\left.\mathrm{KBr}, v_{\max } \mathrm{cm}^{-1}\right) 3070,2952$, 1647, 1603; ${ }^{1} \mathrm{H}$ NMR $\left(600 \mathrm{MHz}, \mathrm{DMSO}-d_{6}\right) \delta_{\mathrm{H}} 9.41(\mathrm{~s}, 1 \mathrm{H}), 7.88(\mathrm{t}, J=5.83 \mathrm{~Hz}, 1 \mathrm{H})$, $7.58(\mathrm{~d}, J=9.04 \mathrm{~Hz}, 2 \mathrm{H}), 7.40-7.47(\mathrm{~m}, 3 \mathrm{H}), 7.01-7.04(\mathrm{~m}, 3 \mathrm{H}), 6.75(\mathrm{~d}, J=15.81 \mathrm{~Hz}$, $1 \mathrm{H}), 6.69(\mathrm{~d}, J=9.03 \mathrm{~Hz}, 2 \mathrm{H}), 3.81(\mathrm{~s}, 3 \mathrm{H}), 3.10(\mathrm{q}, J=6.40 \mathrm{~Hz}, 2 \mathrm{H}), 2.92(\mathrm{~s}, 6 \mathrm{H}), 1.46$ (sxt, $J=7.30 \mathrm{~Hz}, 2 \mathrm{H}), 0.86(\mathrm{t}, J=7.34 \mathrm{~Hz}, 3 \mathrm{H}) ;{ }^{13} \mathrm{C} \mathrm{NMR}\left(214 \mathrm{MHz}, \mathrm{DMSO}-d_{6}\right) \delta_{\mathrm{C}} 164.3$, 163.1, 158.6, 142.3, 134.5, 133.1, 131.9, 131.4, 129.4, 128.6, 119.0, 114.6, 113.9, 113.2, 55.3, 41.5, 40.5, 39.8, 39.7, 39.6, 39.5, 39.4, 39.3, 39.2, 22.1, 11.3; LC/MS (ESI), RT = $3.7 \mathrm{~min}, \mathrm{~m} / \mathrm{z} 408(\mathrm{M}+1)$. 


\subsubsection{5. (Z)-3-[4-(dimethylamino)phenyl]-N-propyl-2-[(E)-3-(p-}

\section{tolyl)acrylamido]acrylamide (3012)}

This compound was prepared according to the procedure described for the synthesis of 1502 starting from 4-[(Z)-4-(dimethylamino)benzylidene]-2-[(E)-4-methylstyryl]oxazol5(4H)-one $(0.332 \mathrm{~g}, 1 \mathrm{mmol})$ and $n$-propylamine $(0.16 \mathrm{~mL}, 2 \mathrm{mmol})$. The product 3012 was a yellow solid (341 mg, 87\%), Mp 218-219 ${ }^{\circ} \mathrm{C}$. IR ( $\left.\mathrm{KBr}, v_{\max } \mathrm{cm}^{-1}\right) 3268,2952,1647$, 1601; ${ }^{1} \mathrm{H}$ NMR (850 MHz, DMSO- $\left.d_{6}\right) \delta$ ppm 9.51 (br. s., $\left.1 \mathrm{H}\right) 7.96$ (t, $J=5.97 \mathrm{~Hz}, 1 \mathrm{H}$ ) $7.45-7.52(\mathrm{~m}, 3 \mathrm{H}) 7.26(\mathrm{~m}, J=7.78 \mathrm{~Hz}, 2 \mathrm{H}) 7.21(\mathrm{~s}, 1 \mathrm{H}) 7.04(\mathrm{~s}, 1 \mathrm{H}) 6.99(\mathrm{~d}, J=8.30$ Hz, 1 H) $6.84(\mathrm{~d}, J=15.57 \mathrm{~Hz}, 1 \mathrm{H}) 6.76(\mathrm{~d}, J=8.30 \mathrm{~Hz}, 1 \mathrm{H}) 3.11(\mathrm{q}, J=6.57 \mathrm{~Hz}, 2 \mathrm{H}) 2.51$ (br. s., 6 H) 2.34 (s, 3H) 1.47 (sxt, J=7.16 Hz, 2 H) 0.85 - 0.87 (m, 3 H); LC/MS (ESI), RT $=5.0 \mathrm{~min}, \mathrm{~m} / \mathrm{z} 392(\mathrm{M}+1)$.

\subsubsection{6. (Z)-3-[4-(dimethylamino)phenyl]-N-propyl-2-[(E)-3-(thien-2-}

yl)acrylamido]acrylamide (3112)

This compound was prepared according to the procedure described for the synthesis of 1502 starting from 4-[(Z)-4-(dimethylamino)benzylidene]-2-[(E)-2-(thien-3-yl)vinyl]oxazol-5(4H)-one $(0.324 \mathrm{~g}, 1 \mathrm{mmol})$ and $n$-propylamine $(0.16 \mathrm{~mL}, 2 \mathrm{mmol})$. The product 3112 was an off-white solid (352 mg, 92\%), Mp 208-209 ${ }^{\circ} \mathrm{C}$. IR (KBr, $\left.v_{\max } \mathrm{cm}^{-1}\right) 3296$, 2948, 1643, 1605; ${ }^{1} \mathrm{H}$ NMR (600 MHz, DMSO- $\left.d_{6}\right) \delta_{\mathrm{H}} 9.47(\mathrm{~s}, 1 \mathrm{H}), 7.90(\mathrm{t}, J=5.83 \mathrm{~Hz}$, 1H), $7.61-7.68(\mathrm{~m}, 2 \mathrm{H}), 7.44(\mathrm{~d}, J=3.39 \mathrm{~Hz}, 1 \mathrm{H}), 7.40(\mathrm{~d}, J=9.04 \mathrm{~Hz}, 2 \mathrm{H}), 7.15(\mathrm{dd}, J$ $=3.58,5.08 \mathrm{~Hz}, 1 \mathrm{H}), 7.03(\mathrm{~s}, 1 \mathrm{H}), 6.70(\mathrm{~d}, J=9.03 \mathrm{~Hz}, 2 \mathrm{H}), 6.64(\mathrm{~d}, J=15.81 \mathrm{~Hz}, 1 \mathrm{H})$, 3.09 (q, $J=6.40 \mathrm{~Hz}, 2 \mathrm{H}), 2.93(\mathrm{~s}, 6 \mathrm{H}), 1.46(\mathrm{sxt}, J=7.30 \mathrm{~Hz}, 2 \mathrm{H}), 0.85$ (t, $J=7.34 \mathrm{~Hz}$, 3H); LC/MS (ESI), RT = $3.5 \mathrm{~min}, \mathrm{~m} / \mathrm{z} 384(\mathrm{M}+1)$. 


\subsubsection{7. (Z)-2-cinnamamido-3-(4-hydroxy-3-methoxyphenyl)-N-propylacrylamide}

(3212)

This compound was prepared according to the procedure described for the synthesis of 1502 starting from 4-[(Z)-4-hydroxy-3-methoxybenzylidene]-2-[(E)-styryl]oxazol-5(4H)one $(0.321 \mathrm{~g}, 1 \mathrm{mmol})$ and $n$-propylamine $(0.16 \mathrm{~mL}, 2 \mathrm{mmol})$. The product 3212 was an off-white solid (323 mg, 85\%), Mp 199-200 ${ }^{\circ} \mathrm{C}$. IR (KBr, $\left.v_{\max } \mathrm{cm}^{-1}\right) 3292,2971,1650$, 1610; ${ }^{1} \mathrm{H}$ NMR (600 MHz, DMSO-d6) $\delta_{\mathrm{H}} 8.02$ (br. s., 1H), 7.61 (d, $\left.J=7.15 \mathrm{~Hz}, 2 \mathrm{H}\right), 7.39$ - $7.55(\mathrm{~m}, 4 \mathrm{H}), 7.21(\mathrm{~s}, 1 \mathrm{H}), 7.04(\mathrm{~s}, 1 \mathrm{H}), 6.91(\mathrm{~d}, J=16.19 \mathrm{~Hz}, 1 \mathrm{H}), 6.77(\mathrm{~d}, J=8.28 \mathrm{~Hz}$ $1 \mathrm{H}), 3.69(\mathrm{~s}, 3 \mathrm{H}), 3.11(\mathrm{q}, J=6.65 \mathrm{~Hz}, 2 \mathrm{H}), 1.47(\mathrm{sxt}, J=7.15 \mathrm{~Hz}, 2 \mathrm{H}), 0.86(\mathrm{t}, J=7.34$ $\mathrm{Hz}, 3 \mathrm{H}) ;{ }^{13} \mathrm{C}$ NMR $\left(214 \mathrm{MHz}, \mathrm{DMSO}-d_{6}\right) \delta_{\mathrm{C}} 165.2,164.8,147.5,147.3,139.8,134.9$, $129.9,129.2,128.6,127.7,127.2,125.5,123.8,121.8,115.5,112.9,55.4,41.0,39.8,39.7$, 39.6, 39.5, 39.4, 39.3, 39.2, 22.5, 11.5; LC/MS (ESI), RT = 2.9 min, m/z $381(\mathrm{M}+1)$.

\subsubsection{8. (Z)-2-[(E)-3-(4-chlorophenyl)acrylamido]-3-(4-hydroxy-3-methoxyphenyl)-N- propylacrylamide (3312)}

This compound was prepared according to the procedure described for the synthesis of 1502 starting from 2-[(E)-4-chlorostyryl]-4-[(Z)-4-hydroxy-3-methoxybenzylidene]oxazol-5(4H)-one $(0.355 \mathrm{~g}, 1 \mathrm{mmol})$ and $n$-propylamine $(0.16 \mathrm{~mL}, 2 \mathrm{mmol})$. The product 3312 was a yellow solid (356 mg, 86\%), Mp 136-137 ${ }^{\circ} \mathrm{C} . \mathrm{IR}\left(\mathrm{KBr}, v_{\max } \mathrm{cm}^{-1}\right)$ 3566, 2988, 2902, 1650; ${ }^{1} \mathrm{H}$ NMR (600 MHz, DMSO- $\left.d_{6}\right) \delta_{\mathrm{H}} 9.61$ (br. s., $\left.1 \mathrm{H}\right), 8.01(\mathrm{t}, J=5.83 \mathrm{~Hz}, 1 \mathrm{H})$, $7.64(\mathrm{~d}, J=8.28 \mathrm{~Hz}, 2 \mathrm{H}), 7.48-7.56(\mathrm{~m}, 3 \mathrm{H}), 7.20(\mathrm{~d}, J=2.26 \mathrm{~Hz}, 1 \mathrm{H}), 7.04(\mathrm{~s}, 1 \mathrm{H}), 6.99$ $(\mathrm{dd}, J=1.88,8.28 \mathrm{~Hz}, 1 \mathrm{H}), 6.90(\mathrm{~d}, J=16.19 \mathrm{~Hz}, 1 \mathrm{H}), 6.76(\mathrm{~d}, J=8.28 \mathrm{~Hz}, 1 \mathrm{H}), 3.68(\mathrm{~s}$, $3 \mathrm{H}), 3.11(\mathrm{q}, J=6.65 \mathrm{~Hz}, 2 \mathrm{H}), 1.47$ (sxt, $J=7.23 \mathrm{~Hz}, 2 \mathrm{H}), 0.86(\mathrm{t}, J=7.34 \mathrm{~Hz}, 3 \mathrm{H})$; LC/MS (ESI), RT = $3.4 \mathrm{~min}, \mathrm{~m} / \mathrm{z} 415(\mathrm{M}+1), 416(\mathrm{M}+2)$. 


\subsubsection{9. (Z)-3-(4-hydroxy-3-methoxyphenyl)-2-[(E)-3-(4-methoxyphenyl)acrylamido]-N-} propylacrylamide (3412)

This compound was prepared according to the procedure described for the synthesis of 1502 starting from 4-[(Z)-4-hydroxy-3-methoxybenzylidene]-2-[(E)-4-methoxystyryl]oxazol-5(4H)-one $(0.351 \mathrm{~g}, 1 \mathrm{mmol})$ and $n$-propylamine $(0.16 \mathrm{~mL}, 2 \mathrm{mmol})$. The product 3412 was an orange solid (332 mg, 81\%), Mp 180-181 ${ }^{\circ} \mathrm{C} . \mathrm{IR}\left(\mathrm{KBr}, v_{\max } \mathrm{cm}^{-1}\right) 3567,2989$, 2955, 1655; ${ }^{1} \mathrm{H}$ NMR (600 MHz, DMSO-d6) $\delta_{\mathrm{H}} 9.49$ (br. s., $\left.1 \mathrm{H}\right), 7.97$ (t, $\left.J=6.02 \mathrm{~Hz}, 1 \mathrm{H}\right)$, $7.56(\mathrm{~d}, J=8.28 \mathrm{~Hz}, 2 \mathrm{H}), 7.46(\mathrm{~d}, J=15.81 \mathrm{~Hz}, 1 \mathrm{H}), 7.21(\mathrm{~d}, J=1.88 \mathrm{~Hz}, 1 \mathrm{H}), 7.00-7.03$ (m, 3H), $6.99(\mathrm{dd}, J=1.88,8.28 \mathrm{~Hz}, 1 \mathrm{H}), 6.77(\mathrm{~d}, J=6.78 \mathrm{~Hz}, 1 \mathrm{H}), 6.75(\mathrm{~s}, 1 \mathrm{H}), 3.81(\mathrm{~s}$, $3 \mathrm{H}), 3.68(\mathrm{~s}, 3 \mathrm{H}), 3.11(\mathrm{q}, J=6.65 \mathrm{~Hz}, 2 \mathrm{H}), 1.47(\mathrm{sxt}, J=7.23 \mathrm{~Hz}, 2 \mathrm{H}), 0.86(\mathrm{t}, J=7.34$ $\mathrm{Hz}, 3 \mathrm{H}) ; \mathrm{LC} / \mathrm{MS}(\mathrm{ESI}), \mathrm{RT}=2.7 \mathrm{~min}, \mathrm{~m} / \mathrm{z} 411(\mathrm{M}+1)$.

\subsubsection{0. (Z)-3-(4-hydroxy-3-methoxyphenyl)-N-propyl-2-[(E)-3-(p-}

\section{tolyl)acrylamido]acrylamide (3512)}

This compound was prepared according to the procedure described for the synthesis of 1502 starting from 4-[(Z)-4-hydroxy-3-methoxybenzylidene]-2-[(E)-4-methylstyryl]oxazol-5(4H)-one $(0.335 \mathrm{~g}, 1 \mathrm{mmol})$ and $n$-propylamine $(0.16 \mathrm{~mL}, 2 \mathrm{mmol})$. The product 3512 was a yellow solid (296 mg, 75\%), Mp 183-184 ${ }^{\circ} \mathrm{C} . \mathrm{IR}\left(\mathrm{KBr}, v_{\max } \mathrm{cm}^{-1}\right)$ 3566, 3213, 2947, 1663; ${ }^{1} \mathrm{H}$ NMR (600 MHz, DMSO-d6) $\delta_{\mathrm{H}} 9.54$ (s, 1H), 9.39 (br. s., $\left.1 \mathrm{H}\right), 8.00$ (t, $J=$ $5.65 \mathrm{~Hz}, 1 \mathrm{H}), 7.44-7.53(\mathrm{~m}, 3 \mathrm{H}), 7.27(\mathrm{~d}, J=7.91 \mathrm{~Hz}, 2 \mathrm{H}), 7.21(\mathrm{~s}, 1 \mathrm{H}), 7.03(\mathrm{~s}, 1 \mathrm{H})$, $6.99(\mathrm{dd}, J=1.88,8.28 \mathrm{~Hz}, 1 \mathrm{H}), 6.85(\mathrm{~d}, J=15.81 \mathrm{~Hz}, 1 \mathrm{H}), 6.76(\mathrm{~d}, J=8.28 \mathrm{~Hz}, 1 \mathrm{H}), 3.68$ $(\mathrm{s}, 3 \mathrm{H}), 3.10(\mathrm{q}, J=6.65 \mathrm{~Hz}, 2 \mathrm{H}), 2.35(\mathrm{~s}, 3 \mathrm{H}), 1.47(\mathrm{sxt}, J=7.23 \mathrm{~Hz}, 2 \mathrm{H}), 0.86(\mathrm{t}, J=$ $7.34 \mathrm{~Hz}, 3 \mathrm{H}) ;{ }^{13} \mathrm{C}$ NMR $\left(214 \mathrm{MHz}, \mathrm{DMSO}-d_{6}\right) \delta_{\mathrm{C}} 165.1,164.9,147.5,147.3,139.7,139.6$, 
132.1, 129.7, 128.5, 127.7, 127.3, 125.5, 123.7, 120.8, 115.4, 112.9, 55.3, 41.0, 39.8, 39.7, 39.6, 39.5, 39.4, 39.3, 39.2, 22.5, 11.5; LC/MS (ESI), RT = $3.3 \mathrm{~min}, \mathrm{~m} / \mathrm{z} 395(\mathrm{M}+1)$.

\subsubsection{1. (Z)-3-(4-hydroxy-3-methoxyphenyl)-N-propyl-2-[(E)-3-(thien-2-}

\section{yl)acrylamido]acrylamide (3612)}

This compound was prepared according to the procedure described for the synthesis of 1502 starting from 4-[(Z)-4-hydroxy-3-methoxybenzylidene]-2-[(E)-2-(thien-3-yl)vinyl]oxazol -5(4H)-one $(0.327 \mathrm{~g}, 1 \mathrm{mmol})$ and $n$-propylamine $(0.16 \mathrm{~mL}, 2 \mathrm{mmol})$. The product 3612 was a yellow solid (340 mg, 88\%), Mp 192-93 ${ }^{\circ} \mathrm{C}$. IR $\left(\mathrm{KBr}, v_{\max } \mathrm{cm}^{-1}\right) 3560,3105$, 2954, 1648, 1603; ${ }^{1} \mathrm{H}$ NMR (600 MHz, DMSO- $\left.d_{6}\right) \delta_{\mathrm{H}} 9.54$ (br. s., $\left.1 \mathrm{H}\right), 7.99$ (t, $J=5.83$ Hz, 1H), $7.63-7.68(\mathrm{~m}, 2 \mathrm{H}), 7.43(\mathrm{~d}, J=3.39 \mathrm{~Hz}, 1 \mathrm{H}), 7.19(\mathrm{~d}, J=1.88 \mathrm{~Hz}, 1 \mathrm{H}), 7.13-$ $7.16(\mathrm{~m}, 1 \mathrm{H}), 7.04(\mathrm{~s}, 1 \mathrm{H}), 6.98(\mathrm{dd}, J=1.88,8.28 \mathrm{~Hz}, 1 \mathrm{H}), 6.76(\mathrm{~d}, J=7.91 \mathrm{~Hz}, 1 \mathrm{H}), 6.66$ (d, $J=15.81 \mathrm{~Hz}, 1 \mathrm{H}), 3.69(\mathrm{~s}, 3 \mathrm{H}), 3.11(\mathrm{q}, J=6.65 \mathrm{~Hz}, 2 \mathrm{H}), 1.46(\mathrm{sxt}, J=7.23 \mathrm{~Hz}, 2 \mathrm{H})$, $0.86(\mathrm{t}, J=7.34 \mathrm{~Hz}, 3 \mathrm{H}) ; \mathrm{LC} / \mathrm{MS}(\mathrm{ESI}), \mathrm{RT}=2.7 \mathrm{~min}, \mathrm{~m} / \mathrm{z} 387(\mathrm{M}+1)$.

\subsubsection{2. (Z)-2-cinnamamido-3-(1H-indol-3-yl)-N-propylacrylamide (3712)}

This compound was prepared according to the procedure described for the synthesis of 1502 starting from (Z)-4-[(1H-indol-3-yl)methylene]-2-[(E)-styryl]oxazol-5(4H)-one $(0.314 \mathrm{~g}, 1 \mathrm{mmol})$ and $n$-propylamine $(0.16 \mathrm{~mL}, 2 \mathrm{mmol})$. The product 3712 was a white solid (287 mg, 77\%), Mp 249-250 ${ }^{\circ} \mathrm{C}$. IR (KBr, $\left.v_{\max } \mathrm{cm}^{-1}\right)$ 3401, 3057, 2956, 1650, 1608;

${ }^{1} \mathrm{H}$ NMR (600 MHz, DMSO-d $d_{6}$ ) $\delta_{\text {H }} 11.56$ (br. s., $1 \mathrm{H}$ ), 9.46 (s, $1 \mathrm{H}$ ), 7.98 (t, $J=5.83 \mathrm{~Hz}$, 1H), $7.74(\mathrm{~d}, J=7.91 \mathrm{~Hz}, 1 \mathrm{H}), 7.63-7.67(\mathrm{~m}, 3 \mathrm{H}), 7.42-7.55(\mathrm{~m}, 6 \mathrm{H}), 7.17(\mathrm{t}, J=7.53$ $\mathrm{Hz}, 1 \mathrm{H}), 7.12(\mathrm{t}, J=7.53 \mathrm{~Hz}, 1 \mathrm{H}), 6.98(\mathrm{~d}, J=15.81 \mathrm{~Hz}, 1 \mathrm{H}), 3.14(\mathrm{q}, J=6.53 \mathrm{~Hz}, 2 \mathrm{H})$, $1.50(\mathrm{sxt}, J=7.23 \mathrm{~Hz}, 2 \mathrm{H}), 0.88(\mathrm{t}, J=7.34 \mathrm{~Hz}, 3 \mathrm{H}) ;{ }^{13} \mathrm{C}$ NMR $\left(214 \mathrm{MHz}, \mathrm{DMSO}-d_{6}\right) \delta_{\mathrm{C}}$ $164.5,164.2,141.5,135.5,134.8,129.6,129.3,129.1,129.0,128.7,127.9,124.9,124.6$, 
122.1, 120.0, 118.2, 111.9, 110.0, 41.0, 39.8, 39.7, 39.6, 39.5, 39.4, 39.3, 39.2, 22.3, 11.5;

LC/MS (ESI), RT = $3.3 \mathrm{~min}, \mathrm{~m} / \mathrm{z} 374(\mathrm{M}+1)$.

\subsubsection{3. (Z)-2-[(E)-3-(4-chlorophenyl)acrylamido]-3-(1H-indol-3-yl)- $\mathrm{N}$ -} propylacrylamide (3812)

This compound was prepared according to the procedure described for the synthesis of 1502 starting from (Z)-4-[(1H-indol-3-yl)methylene]-2-[(E)-4-chlorostyryl]oxazol-5(4H)one $(0.348 \mathrm{~g}, 1 \mathrm{mmol})$ and $n$-propylamine $(0.16 \mathrm{~mL}, 2 \mathrm{mmol})$. The product 3812 was an orange solid (330 mg, 81\%), Mp 210-211 ${ }^{\circ} \mathrm{C}$. IR $\left(\mathrm{KBr}, v_{\max } \mathrm{cm}^{-1}\right) 3208,1650,1615 ;{ }^{1} \mathrm{H}$ NMR (600 MHz, DMSO- $\left.d_{6}\right) \delta_{\mathrm{H}} 11.56$ (br. s., $\left.1 \mathrm{H}\right), 9.47$ (s, $\left.1 \mathrm{H}\right), 7.98(\mathrm{t}, J=5.83 \mathrm{~Hz}, 1 \mathrm{H})$, $7.73(\mathrm{~d}, J=7.91 \mathrm{~Hz}, 1 \mathrm{H}), 7.68(\mathrm{~d}, J=8.66 \mathrm{~Hz}, 2 \mathrm{H}), 7.65(\mathrm{~d}, J=2.63 \mathrm{~Hz}, 1 \mathrm{H}), 7.50-7.56$ (m, 4H), $7.43(\mathrm{~d}, J=7.91 \mathrm{~Hz}, 1 \mathrm{H}), 7.17(\mathrm{t}, J=7.15 \mathrm{~Hz}, 1 \mathrm{H}), 7.12(\mathrm{t}, J=7.34 \mathrm{~Hz}, 1 \mathrm{H}), 6.98$ $(\mathrm{d}, J=15.81 \mathrm{~Hz}, 1 \mathrm{H}), 3.14(\mathrm{q}, J=6.53 \mathrm{~Hz}, 2 \mathrm{H}), 1.50(\mathrm{sxt}, J=7.30 \mathrm{~Hz}, 2 \mathrm{H}), 0.88(\mathrm{t}, J=$ $7.53 \mathrm{~Hz}, 3 \mathrm{H}) ;{ }^{13} \mathrm{C}$ NMR (214 MHz, DMSO- $\left.d_{6}\right) \delta_{\mathrm{C}} 165.7,165.3,140.5,138.1,135.7,134.2$, 132.3, 132.2, 130.7, 130.6, 130.5, 130.1, 129.8, 125.1, 123.9, 122.7, 113.7, 111.5, 110.1, 41.6, 39.8, 39.7, 39.6, 39.5, 39.4, 39.3, 39.2, 23.0, 11.6; LC/MS (ESI), RT = $4.2 \mathrm{~min}, \mathrm{~m} / \mathrm{z}$ $408(\mathrm{M}+1), 409(\mathrm{M}+2)$.

\subsubsection{4. (Z)-3-(1H-indol-3-yl)-2-[(E)-3-(4-methoxyphenyl)acrylamido]- $N$ -}

\section{propylacrylamide (3912)}

This compound was prepared according to the procedure described for the synthesis of 1502 starting from (Z)-4-[(1H-indol-3-yl)methylene]-2-[(E)-4-methoxystyryl]oxazol5(4H)-one $(0.344 \mathrm{~g}, 1 \mathrm{mmol})$ and $n$-propylamine $(0.16 \mathrm{~mL}, 2 \mathrm{mmol})$. The product 3912 was an orange solid (335 mg, 83\%), Mp 225-226 ${ }^{\circ} \mathrm{C}$. IR ( KBr, $\left.v_{\max } \mathrm{cm}^{-1}\right) 3181,1650,1615$; ${ }^{1} \mathrm{H}$ NMR (600 MHz, DMSO- $d_{6}$ ) $\delta_{\mathrm{H}} 11.55$ (br. s., $1 \mathrm{H}$ ), 9.36 (s, $\left.1 \mathrm{H}\right), 7.95$ (t, $J=5.83 \mathrm{~Hz}$, 
$1 \mathrm{H}), 7.73(\mathrm{~d}, J=7.91 \mathrm{~Hz}, 1 \mathrm{H}), 7.64(\mathrm{~d}, J=2.26 \mathrm{~Hz}, 1 \mathrm{H}), 7.60(\mathrm{~d}, J=8.66 \mathrm{~Hz}, 2 \mathrm{H}), 7.46-$ $7.50(\mathrm{~m}, 2 \mathrm{H}), 7.43(\mathrm{~d}, J=7.91 \mathrm{~Hz}, 1 \mathrm{H}), 7.17(\mathrm{t}, J=7.53 \mathrm{~Hz}, 1 \mathrm{H}), 7.12(\mathrm{t}, J=7.53 \mathrm{~Hz}, 1 \mathrm{H})$, $7.03(\mathrm{~d}, J=8.66 \mathrm{~Hz}, 2 \mathrm{H}), 6.84(\mathrm{~d}, J=15.81 \mathrm{~Hz}, 1 \mathrm{H}), 3.82(\mathrm{~s}, 3 \mathrm{H}), 3.14(\mathrm{q}, J=6.27 \mathrm{~Hz}$, 2H), 1.49 (sxt, $J=7.23 \mathrm{~Hz}, 2 \mathrm{H}), 0.88$ (t, $J=7.34 \mathrm{~Hz}, 3 \mathrm{H}) ;{ }^{13} \mathrm{C}$ NMR $(214 \mathrm{MHz}$, DMSO$\left.d_{6}\right) \delta_{\mathrm{C}} 166.0,164.3,160.6,141.5,138.5,137.1,132.3,131.9,131.4,129.2,123.5,122.2$, 121.0, 120.6, 114.6, 113.9, 112.5, 112.3, 55.8, 41.5, 39.8, 39.7, 39.6, 39.5, 39.4, 39.3, 39.2, 22.6, 11.5; LC/MS (ESI), RT = $3.2 \mathrm{~min}, \mathrm{~m} / \mathrm{z} 404(\mathrm{M}+1)$.

\subsubsection{5. (Z)-3-(1H-indol-3-yl)-N-propyl-2-[(E)-3-(p-tolyl)acrylamido]acrylamide (4012)}

This compound was prepared according to the procedure described for the synthesis of 1502 starting from (Z)-4-[(1H-indol-3-yl)methylene]-2-[(E)-4-methylstyryl]oxazol5(4H)-one $(0.328 \mathrm{~g}, 1 \mathrm{mmol})$ and $n$-propylamine $(0.16 \mathrm{~mL}, 2 \mathrm{mmol})$. The product 4012 was a yellow solid (345 mg, 89\%), Mp 192-193 ${ }^{\circ} \mathrm{C}$. IR ( $\left.\mathrm{KBr}, v_{\max } \mathrm{cm}^{-1}\right) 3220,2950,1651$, 1595; ${ }^{1} \mathrm{H}$ NMR (600 MHz, DMSO- $\left.d_{6}\right) \delta_{\mathrm{H}} 11.56$ (br. s., $\left.1 \mathrm{H}\right), 9.42$ (s, $\left.1 \mathrm{H}\right), 7.97$ (t, $J=5.83$ $\mathrm{Hz}, 1 \mathrm{H}), 7.73(\mathrm{~d}, J=7.91 \mathrm{~Hz}, 1 \mathrm{H}), 7.65(\mathrm{~s}, 1 \mathrm{H}), 7.54(\mathrm{~d}, J=7.91 \mathrm{~Hz}, 2 \mathrm{H}), 7.47-7.52(\mathrm{~m}$, 2H), $7.43(\mathrm{~d}, J=7.91 \mathrm{~Hz}, 1 \mathrm{H}), 7.28(\mathrm{~d}, J=7.91 \mathrm{~Hz}, 2 \mathrm{H}), 7.17(\mathrm{t}, J=7.53 \mathrm{~Hz}, 1 \mathrm{H}), 7.12(\mathrm{t}$, $J=7.53 \mathrm{~Hz}, 1 \mathrm{H}), 6.93(\mathrm{~d}, J=15.81 \mathrm{~Hz}, 1 \mathrm{H}), 3.14(\mathrm{q}, J=6.40 \mathrm{~Hz}, 2 \mathrm{H}), 2.36(\mathrm{~s}, 3 \mathrm{H}), 1.50$ (sxt, $J=7.30 \mathrm{~Hz}, 2 \mathrm{H}), 0.88(\mathrm{t}, J=7.53 \mathrm{~Hz}, 3 \mathrm{H}) ;{ }^{13} \mathrm{C} \mathrm{NMR}\left(214 \mathrm{MHz}, \mathrm{DMSO}-d_{6}\right) \delta_{\mathrm{C}} 165.1$, 164.6, 141.5, 139.6, 135.5, 129.8, 129.6, 129.2, 127.9, 127.7, 127.6, 122.2, 121.3, 121.1, $118.2,112.5,111.9,110.0,40.9,39.8,39.7,39.6,39.5,39.4,39.3,39.2,22.6,21.0,11.5$ LC/MS (ESI), RT = $3.7 \mathrm{~min}, \mathrm{~m} / \mathrm{z} 388(\mathrm{M}+1)$. 


\subsubsection{6. (Z)-3-(1H-indol-3-yl)-N-propyl-2-[(E)-3-(thien-2-yl)acrylamido]acrylamide} (4112)

This compound was prepared according to the procedure described for the synthesis of 1502 starting from (Z)-4-[(1H-indol-3-yl)methylene]-2-[(E)-2-(thien-3-yl)vinyl]oxazol5(4H)-one $(0.320 \mathrm{~g}, 1 \mathrm{mmol})$ and $n$-propylamine $(0.16 \mathrm{~mL}, 2 \mathrm{mmol})$. The product 4112 was a yellow solid (326 mg, 86\%), Mp 244-245 ${ }^{\circ} \mathrm{C}$. IR ( $\left.\mathrm{KBr}, v_{\max } \mathrm{cm}^{-1}\right) 3567,3997,2950$, 1650; ${ }^{1} \mathrm{H}$ NMR (600 MHz, DMSO-d $\left.d_{6}\right) \delta_{\mathrm{H}} 11.56$ (br. s., $\left.1 \mathrm{H}\right), 9.41$ (s, $\left.1 \mathrm{H}\right), 7.96$ (t, $J=5.83$ $\mathrm{Hz}, 1 \mathrm{H}), 7.72(\mathrm{~d}, J=7.91 \mathrm{~Hz}, 1 \mathrm{H}), 7.65-7.70(\mathrm{~m}, 2 \mathrm{H}), 7.64(\mathrm{~d}, J=1.88 \mathrm{~Hz}, 1 \mathrm{H}), 7.50(\mathrm{~s}$, 1H), $7.42-7.46(\mathrm{~m}, 2 \mathrm{H}), 7.14-7.19(\mathrm{~m}, 2 \mathrm{H}), 7.12(\mathrm{t}, J=7.53 \mathrm{~Hz}, 1 \mathrm{H}), 6.73(\mathrm{~d}, J=15.43$ $\mathrm{Hz}, 1 \mathrm{H}), 3.13(\mathrm{q}, J=6.40 \mathrm{~Hz}, 2 \mathrm{H}), 1.49(\mathrm{sxt}, J=7.23 \mathrm{~Hz}, 2 \mathrm{H}), 0.88(\mathrm{t}, J=7.53 \mathrm{~Hz}, 3 \mathrm{H})$;

${ }^{13} \mathrm{C}$ NMR (214 MHz, DMSO- $\left.d_{6}\right) \delta_{\mathrm{C}} 163.8,163.2,139.7,138.1,136.5,136.2,133.4,133.3$, $132.4,129.1,128.3,123.6,122.9,122.2,121.1,120.6,112.3,107.4,41.4,39.8,39.7,39.6$, 39.5, 39.4, 39.3, 39.2, 22.3, 11.3; LC/MS (ESI), RT = $3.1 \mathrm{~min}, \mathrm{~m} / \mathrm{z} 380(\mathrm{M}+1)$.

\subsubsection{7. (Z)-2-cinnamamido-N-propyl-3-(pyridin-3-yl)acrylamide (4212)}

This compound was prepared according to the procedure described for the synthesis of 1502 starting from (Z)-4-(pyridin-3-ylmethylene)-2-[(E)-styryl]oxazol-5(4H)-one (0.276 g, $1 \mathrm{mmol})$ and $n$-propylamine $(0.16 \mathrm{~mL}, 2 \mathrm{mmol})$. The product $\mathbf{4 2 1 2}$ was a white solid (248 mg, 74\%), Mp 189-190 ${ }^{\circ} \mathrm{C}$. IR (KBr, $\left.v_{\max } \mathrm{cm}^{-1}\right)$ 3258, 2964, 1649, 1610; ${ }^{1} \mathrm{H}$ NMR (600 MHz, DMSO- $\left.d_{6}\right) \delta_{\mathrm{H}} 9.82(\mathrm{~s}, 1 \mathrm{H}), 8.70(\mathrm{~d}, J=2.26 \mathrm{~Hz}, 1 \mathrm{H}), 8.47(\mathrm{dd}, J=1.69,4.71 \mathrm{~Hz}$, $1 \mathrm{H}), 8.25(\mathrm{t}, J=5.65 \mathrm{~Hz}, 1 \mathrm{H}), 7.92(\mathrm{td}, J=1.74,8.19 \mathrm{~Hz}, 1 \mathrm{H}), 7.60-7.66(\mathrm{~m}, 2 \mathrm{H}), 7.51$ (d, $J=15.81 \mathrm{~Hz}, 1 \mathrm{H}), 7.39-7.49(\mathrm{~m}, 4 \mathrm{H}), 7.00(\mathrm{~s}, 1 \mathrm{H}), 6.86(\mathrm{~d}, J=16.19 \mathrm{~Hz}, 1 \mathrm{H}), 3.13$ $(\mathrm{q}, J=6.40 \mathrm{~Hz}, 2 \mathrm{H}), 1.49(\mathrm{sxt}, J=7.30 \mathrm{~Hz}, 2 \mathrm{H}), 0.88(\mathrm{t}, J=7.34 \mathrm{~Hz}, 3 \mathrm{H}) ;{ }^{13} \mathrm{C}$ NMR $(214$ MHz, DMSO- $\left.d_{6}\right) \delta_{\mathrm{C}} 164.7,164.5,150.1,148.9,140.3,135.9,134.7,132.2,130.5,129.9$, 
129.1, 127.8, 123.7, 123.2, 121.4, 41.0, 39.8, 39.7, 39.6, 39.5, 39.4, 39.3, 39.2, 22.4, 11.5;

LC/MS (ESI), RT = $2.7 \mathrm{~min}, \mathrm{~m} / \mathrm{z} 336(\mathrm{M}+1)$.

\subsubsection{8. (Z)-2-[(E)-3-(4-chlorophenyl)acrylamido]-N-propyl-3-(pyridin-3-yl)acrylamide} (4312)

This compound was prepared according to the procedure described for the synthesis of 1502 starting from (Z)-2-[(E)-4-chlorostyryl]-4-(pyridin-3-ylmethylene)oxazol-5(4H)-one (0.310 g, $1 \mathrm{mmol})$ and $n$-propylamine $(0.16 \mathrm{~mL}, 2 \mathrm{mmol})$. The product 4312 was a white solid (288 mg, 78\%), Mp 191-192 ${ }^{\circ} \mathrm{C}$. IR (KBr, $\left.v_{\max } \mathrm{cm}^{-1}\right) 3261,2964,1649,1609 ;{ }^{1} \mathrm{H}$ NMR (600 MHz, DMSO- $\left.d_{6}\right) \delta_{\mathrm{H}} 9.83$ (br. s., $\left.1 \mathrm{H}\right), 8.70$ (d, $\left.J=2.26 \mathrm{~Hz}, 1 \mathrm{H}\right), 8.47$ (dd, $J=$ 1.69, $4.71 \mathrm{~Hz}, 1 \mathrm{H}), 8.25(\mathrm{t}, J=5.46 \mathrm{~Hz}, 1 \mathrm{H}), 7.92(\mathrm{~d}, J=7.91 \mathrm{~Hz}, 1 \mathrm{H}), 7.63(\mathrm{~d}, J=7.15$ Hz, 2H), $7.51(\mathrm{~d}, J=15.81 \mathrm{~Hz}, 1 \mathrm{H}), 7.44-7.48(\mathrm{~m}, 2 \mathrm{H}), 7.40$ - 7.44 (m, 2H), 7.00 (s, 1H), $6.86(\mathrm{~d}, J=15.81 \mathrm{~Hz}, 1 \mathrm{H}), 3.13(\mathrm{q}, J=6.53 \mathrm{~Hz}, 2 \mathrm{H}), 1.49(\mathrm{sxt}, J=7.30 \mathrm{~Hz}, 2 \mathrm{H}), 0.88(\mathrm{t}$, $J=7.34 \mathrm{~Hz}, 3 \mathrm{H})$.

\subsubsection{9. (Z)-2-[(E)-3-(4-methoxyphenyl)acrylamido]-N-propyl-3-(pyridin-3-} yl)acrylamide (4412)

This compound was prepared according to the procedure described for the synthesis of 1502 starting from (Z)-2-[(E)-4-methoxystyryl]-4-(pyridin-3-ylmethylene)oxazol-5(4H)one $(0.306 \mathrm{~g}, 1 \mathrm{mmol})$ and $n$-propylamine $(0.16 \mathrm{~mL}, 2 \mathrm{mmol})$. The product 4412 was a white solid (300 mg, 82\%), Mp 185-186 ${ }^{\circ} \mathrm{C}$. IR ( $\left.\mathrm{KBr}, v_{\max } \mathrm{cm}^{-1}\right) 3273,3220,2964,1648$, 1616; ${ }^{1} \mathrm{H}$ NMR (600 MHz, DMSO- $\left.d_{6}\right) \delta_{\mathrm{H}} 9.72(\mathrm{~s}, 1 \mathrm{H}), 8.69$ (s, $\left.1 \mathrm{H}\right), 8.47$ (dd, $J=1.69$, $4.71 \mathrm{~Hz}, 1 \mathrm{H}), 8.22(\mathrm{t}, J=5.27 \mathrm{~Hz}, 1 \mathrm{H}), 7.91(\mathrm{dd}, J=1.32,8.09 \mathrm{~Hz}, 1 \mathrm{H}), 7.57(\mathrm{~d}, J=8.66$ $\mathrm{Hz}, 2 \mathrm{H}), 7.46(\mathrm{~d}, J=15.43 \mathrm{~Hz}, 1 \mathrm{H}), 7.41(\mathrm{dd}, J=4.71,8.09 \mathrm{~Hz}, 1 \mathrm{H}), 7.02(\mathrm{~d}, J=8.66 \mathrm{~Hz}$, 2H), $6.97(\mathrm{~s}, 1 \mathrm{H}), 6.71(\mathrm{~d}, J=15.81 \mathrm{~Hz}, 1 \mathrm{H}), 3.81(\mathrm{~s}, 3 \mathrm{H}), 3.13(\mathrm{q}, J=6.53 \mathrm{~Hz}, 2 \mathrm{H}), 1.49$ 
(sxt, $J=7.23 \mathrm{~Hz}, 2 \mathrm{H}), 0.88(\mathrm{t}, J=7.34 \mathrm{~Hz}, 3 \mathrm{H}),{ }^{13} \mathrm{C}$ NMR $\left(214 \mathrm{MHz}, \mathrm{DMSO}-d_{6}\right) \delta_{\mathrm{C}} 164.8$, $164.4,160.7,150.1,148.9,140.1,135.9,132.3,130.6,129.5,127.3,123.7,123.0,118.8$, 114.6, 55.4, 41.0, 39.8, 39.7, 39.6, 39.5, 39.4, 39.3, 39.2, 22.4, 11.5; LC/MS (ESI), RT = $2.7 \mathrm{~min}, \mathrm{~m} / \mathrm{z} 366(\mathrm{M}+1)$.

\subsubsection{0. (Z)-N-propyl-3-(pyridin-3-yl)-2-[(E)-3-(p-tolyl)acrylamido]acrylamide (4512)}

This compound was prepared according to the procedure described for the synthesis of 1502 starting from (Z)-2-[(E)-4-methylstyryl]-4-(pyridin-3-ylmethylene)oxazol-5(4H)one $(0.290 \mathrm{~g}, 1 \mathrm{mmol})$ and $n$-propylamine $(0.16 \mathrm{~mL}, 2 \mathrm{mmol})$. The product 4512 was a white solid (272 mg, 78\%), Mp 190-191 ${ }^{\circ} \mathrm{C}$. IR (KBr, $\left.v_{\max } \mathrm{cm}^{-1}\right)$ 3270, 2967, 1648, 1608; ${ }^{1} \mathrm{H}$ NMR (600 MHz, DMSO- $\left.d_{6}\right) \delta_{\mathrm{H}} 9.77(\mathrm{~s}, 1 \mathrm{H}), 8.69$ (d, $\left.J=1.88 \mathrm{~Hz}, 1 \mathrm{H}\right), 8.47$ (dd, $J=$ $1.69,4.71 \mathrm{~Hz}, 1 \mathrm{H}), 8.23(\mathrm{t}, J=5.83 \mathrm{~Hz}, 1 \mathrm{H}), 7.92(\mathrm{td}, J=1.60,8.09 \mathrm{~Hz}, 1 \mathrm{H}), 7.52(\mathrm{~d}, J=$ $7.91 \mathrm{~Hz}, 2 \mathrm{H}), 7.47(\mathrm{~d}, J=15.81 \mathrm{~Hz}, 1 \mathrm{H}), 7.41(\mathrm{dd}, J=4.33,8.09 \mathrm{~Hz}, 1 \mathrm{H}), 7.27(\mathrm{~d}, J=7.91$ $\mathrm{Hz}, 2 \mathrm{H}), 6.98(\mathrm{~s}, 1 \mathrm{H}), 6.80(\mathrm{~d}, J=15.81 \mathrm{~Hz}, 1 \mathrm{H}), 3.12(\mathrm{q}, J=6.65 \mathrm{~Hz}, 2 \mathrm{H}), 2.35(\mathrm{~s}, 3 \mathrm{H})$, $1.49(\mathrm{sxt}, J=7.30 \mathrm{~Hz}, 2 \mathrm{H}), 0.88(\mathrm{t}, J=7.34 \mathrm{~Hz}, 3 \mathrm{H}) ;{ }^{13} \mathrm{C}$ NMR $\left(214 \mathrm{MHz}, \mathrm{DMSO}-d_{6}\right) \delta_{\mathrm{C}}$ $164.7,164.6,150.1,148.9,140.3,139.8,135.9,132.3,132.0,130.6,129.7,127.8,123.7$, 123.1, 120.4, 41.1, 39.8, 39.7, 39.6, 39.5, 39.4, 39.3, 39.2, 22.4, 21.1, 11.5; LC/MS (ESI), $\mathrm{RT}=3.1 \mathrm{~min}, \mathrm{~m} / \mathrm{z} 350(\mathrm{M}+1)$.

\subsubsection{1. (Z)-N-propyl-3-(pyridin-3-yl)-2-[(E)-3-(thien-2-yl)acrylamido]acrylamide} (4612)

This compound was prepared according to the procedure described for the synthesis of 1502 starting from (Z)-4-(pyridin-3-ylmethylene)-2-[(E)-2-(thien-3-yl)vinyl]oxazol$5(4 \mathrm{H})$-one $(0.282 \mathrm{~g}, 1 \mathrm{mmol})$ and $n$-propylamine $(0.16 \mathrm{~mL}, 2 \mathrm{mmol})$. The product 4612 was an off-white solid (300 mg, 88\%), Mp 182-183 ${ }^{\circ} \mathrm{C}$. IR (KBr, $\left.v_{\max } \mathrm{cm}^{-1}\right)$ 3270, 2967 , 
1647, 1605; ${ }^{1} \mathrm{H}$ NMR (600 MHz, DMSO-d6) $\delta_{\mathrm{H}} 9.78$ (br. s., $\left.1 \mathrm{H}\right), 8.68$ (d, $\left.J=1.88 \mathrm{~Hz}, 1 \mathrm{H}\right)$, $8.47(\mathrm{dd}, J=1.51,4.89 \mathrm{~Hz}, 1 \mathrm{H}), 8.23(\mathrm{t}, J=5.84 \mathrm{~Hz}, 1 \mathrm{H}), 7.91(\mathrm{td}, J=1.79,8.09 \mathrm{~Hz}, 1 \mathrm{H})$, $7.62-7.70(\mathrm{~m}, 2 \mathrm{H}), 7.39-7.47(\mathrm{~m}, 2 \mathrm{H}), 7.15(\mathrm{dd}, J=3.58,5.08 \mathrm{~Hz}, 1 \mathrm{H}), 6.99(\mathrm{~s}, 1 \mathrm{H})$, $6.60(\mathrm{~d}, J=15.81 \mathrm{~Hz}, 1 \mathrm{H}), 3.12(\mathrm{q}, J=6.65 \mathrm{~Hz}, 2 \mathrm{H}), 1.49(\mathrm{sxt}, J=7.23 \mathrm{~Hz}, 2 \mathrm{H}), 0.88(\mathrm{t}$, $J=7.53 \mathrm{~Hz}, 3 \mathrm{H}) ;{ }^{13} \mathrm{C}$ NMR $\left(214 \mathrm{MHz}, \mathrm{DMSO}-d_{6}\right) \delta_{\mathrm{C}} 164.6,164.2,150.1,148.9,139.7$, $135.9,133.3,132.1,131.5,131.5,130.5,128.6,123.7,123.2,120.1,41.0,39.8,39.7,39.6$, 39.5, 39.4, 39.3, 39.2, 22.3, 11.5; LC/MS (ESI), RT = $2.8 \mathrm{~min}, \mathrm{~m} / \mathrm{z} 342(\mathrm{M}+1)$.

\subsubsection{2. (Z)-2-cinnamamido-3-(4-nitrophenyl)-N-propylacrylamide (4712)}

This compound was prepared according to the procedure described for the synthesis of 1502 starting from 4-[(Z)-4-nitrobenzylidene]-2-[(E)-styryl]oxazol-5(4H)-one (0.320 g, 1 mmol) and $n$-propylamine $(0.16 \mathrm{~mL}, 2 \mathrm{mmol})$. The product 4712 was a white solid (341 mg, 90\%), Mp 211-212 ${ }^{\circ} \mathrm{C}$. IR (KBr, $\left.v_{\max } \mathrm{cm}^{-1}\right)$ 3294, 2958, 1647, 1619; ${ }^{1} \mathrm{H}$ NMR (600 MHz, DMSO-d $\left.d_{6}\right) \delta_{\mathrm{H}} 9.94$ (br. s., $\left.1 \mathrm{H}\right), 8.34$ (t, $\left.J=5.84 \mathrm{~Hz}, 1 \mathrm{H}\right), 8.23$ (d, $\left.J=8.66 \mathrm{~Hz}, 2 \mathrm{H}\right)$, $7.77(\mathrm{~d}, J=9.03 \mathrm{~Hz}, 2 \mathrm{H}), 7.62(\mathrm{~d}, J=7.15 \mathrm{~Hz}, 2 \mathrm{H}), 7.51(\mathrm{~d}, J=15.81 \mathrm{~Hz}, 1 \mathrm{H}), 7.43-7.48$ (m, 3H), $6.96(\mathrm{~s}, 1 \mathrm{H}), 6.86(\mathrm{~d}, J=16.19 \mathrm{~Hz}, 1 \mathrm{H}), 3.13(\mathrm{q}, J=6.65 \mathrm{~Hz}, 2 \mathrm{H}), 1.50$ (sxt, $J=$ $7.30 \mathrm{~Hz}, 2 \mathrm{H}), 0.89(\mathrm{t}, J=7.53 \mathrm{~Hz}, 3 \mathrm{H}) ;{ }^{13} \mathrm{C}$ NMR $\left(214 \mathrm{MHz}, \mathrm{DMSO}-d_{6}\right) \delta_{\mathrm{C}} 164.7,164.3$, $146.4,141.7,140.5,134.7,133.8,130.2,130.0,129.1,127.8,123.7,123.0,121.3,41.1$, 39.8, 39.7, 39.6, 39.5, 39.4, 39.3, 39.2, 22.3, 11.5; LC/MS (ESI), RT = $3.7 \mathrm{~min}, \mathrm{~m} / \mathrm{z} 380$ $(\mathrm{M}+1)$.

\subsubsection{3. (Z)-2-[(E)-3-(4-chlorophenyl)acrylamido]-3-(4-nitrophenyl)-N-}

\section{propylacrylamide (4812)}

This compound was prepared according to the procedure described for the synthesis of 1502 starting from 2-[(E)-4-chlorostyryl]-4-[(Z)-4-nitrobenzylidene]oxazol-5(4H)-one 
$(0.355 \mathrm{~g}, 1 \mathrm{mmol})$ and $n$-propylamine $(0.16 \mathrm{~mL}, 2 \mathrm{mmol})$. The product 4812 was a yellow solid (363 mg, 88\%), Mp 199-200 ㄷ. IR (KBr, $\left.v_{\max } \mathrm{cm}^{-1}\right)$ 3070, 2967, 1648, 1622, 1530, 1350; ${ }^{1} \mathrm{H}$ NMR (600 MHz, DMSO-d6) $\delta_{\mathrm{H}} 9.95$ (s, 1H), 8.34 (t, $\left.J=5.46 \mathrm{~Hz}, 1 \mathrm{H}\right), 8.23$ (d, $J=9.04 \mathrm{~Hz}, 2 \mathrm{H}), 7.77(\mathrm{~d}, J=9.04 \mathrm{~Hz}, 2 \mathrm{H}), 7.65(\mathrm{~d}, J=8.66 \mathrm{~Hz}, 2 \mathrm{H}), 7.50-7.55(\mathrm{~m}, 3 \mathrm{H})$, $6.97(\mathrm{~s}, 1 \mathrm{H}), 6.86(\mathrm{~d}, J=15.81 \mathrm{~Hz}, 1 \mathrm{H}), 3.13(\mathrm{q}, J=6.53 \mathrm{~Hz}, 2 \mathrm{H}), 1.50(\mathrm{sxt}, J=7.23 \mathrm{~Hz}$, 2H), $0.89(\mathrm{t}, J=7.53 \mathrm{~Hz}, 3 \mathrm{H}) ;{ }^{13} \mathrm{C}$ NMR $\left(214 \mathrm{MHz}, \mathrm{DMSO}-d_{6}\right) \delta_{\mathrm{C}} 164.7,164.1,146.4$, $141.7,139.1,134.4,133.7,133.7,130.2,129.5,129.2,123.7,123.1,122.1,41.1,39.8,39.7$, 39.6, 39.5, 39.4, 39.3, 39.2, 22.3, 11.5; LC/MS (ESI), RT = 4.9 min, m/z $414(\mathrm{M}+1), 415$ $(\mathrm{M}+2)$.

\subsubsection{4. (Z)-2-[(E)-3-(4-methoxyphenyl)acrylamido]-3-(4-nitrophenyl)-N-}

\section{propylacrylamide (4912)}

This compound was prepared according to the procedure described for the synthesis of 1502 starting from 2-[(E)-4-methoxystyryl]-4-[(Z)-4-nitrobenzylidene]oxazol-5(4H)-one $(0.350 \mathrm{~g}, 1 \mathrm{mmol})$ and $n$-propylamine $(0.16 \mathrm{~mL}, 2 \mathrm{mmol})$. The product 4912 was a yellow solid (348 mg, 85\%), Mp 235-236 ${ }^{\circ} \mathrm{C}$. IR (KBr, $\left.v_{\max } \mathrm{cm}^{-1}\right)$ 3264, 2967, 1644, 1608, 1520,

1335; ${ }^{1} \mathrm{H}$ NMR (600 MHz, DMSO- $\left.d_{6}\right) \delta_{\mathrm{H}} 9.84$ (br. s., $\left.1 \mathrm{H}\right), 8.31$ (t, $\left.J=5.65 \mathrm{~Hz}, 1 \mathrm{H}\right), 8.23$ $(\mathrm{d}, J=9.04 \mathrm{~Hz}, 2 \mathrm{H}), 7.77(\mathrm{~d}, J=8.66 \mathrm{~Hz}, 2 \mathrm{H}), 7.57(\mathrm{~d}, J=8.66 \mathrm{~Hz}, 2 \mathrm{H}), 7.46(\mathrm{~d}, J=15.81$ $\mathrm{Hz}, 1 \mathrm{H}), 7.02(\mathrm{~d}, J=8.66 \mathrm{~Hz}, 2 \mathrm{H}), 6.93(\mathrm{~s}, 1 \mathrm{H}), 6.71(\mathrm{~d}, J=15.81 \mathrm{~Hz}, 1 \mathrm{H}), 3.81(\mathrm{~s}, 3 \mathrm{H})$, $3.13(\mathrm{q}, J=6.40 \mathrm{~Hz}, 2 \mathrm{H}), 1.50(\mathrm{sxt}, J=7.23 \mathrm{~Hz}, 2 \mathrm{H}), 0.89(\mathrm{t}, J=7.53 \mathrm{~Hz}, 3 \mathrm{H}) ;{ }^{13} \mathrm{C} \mathrm{NMR}$ $\left(214 \mathrm{MHz}, \mathrm{DMSO}-d_{6}\right) \delta_{\mathrm{C}} 164.8,164.6,160.7,146.3,141.8,140.3,134.0,130.1,129.5$, $127.2,123.7,122.6,118.7,114.5,55.4,41.1,39.8,39.7,39.6,39.5,39.4,39.3,39.2,22.3$, 11.5. 


\subsubsection{5. (Z)-3-(4-nitrophenyl)-N-propyl-2-[(E)-3-(p-tolyl)acrylamido]acrylamide (5012)}

This compound was prepared according to the procedure described for the synthesis of 1502 starting from 2-[(E)-4-methylstyryl]-4-[(Z)-4-nitrobenzylidene]oxazol-5(4H)-one $(0.334 \mathrm{~g}, 1 \mathrm{mmol})$ and $n$-propylamine $(0.16 \mathrm{~mL}, 2 \mathrm{mmol})$. The product $\mathbf{5 0 1 2}$ was a yellow solid (350 mg, 89\%), Mp 206-207 ${ }^{\circ} \mathrm{C}$. IR (KBr, $\left.v_{\max } \mathrm{cm}^{-1}\right)$ 3257, 2964, 1647, 1621, 1515, 1340; ${ }^{1} \mathrm{H}$ NMR (600 MHz, DMSO-d6) $\delta_{\mathrm{H}} 9.89$ (s, 1H), 8.33 (t, $\left.J=5.65 \mathrm{~Hz}, 1 \mathrm{H}\right), 8.23$ (d, $J=9.04 \mathrm{~Hz}, 2 \mathrm{H}), 7.77(\mathrm{~d}, J=9.04 \mathrm{~Hz}, 2 \mathrm{H}), 7.45-7.52(\mathrm{~m}, 3 \mathrm{H}), 7.27(\mathrm{~d}, J=7.91 \mathrm{~Hz}, 2 \mathrm{H})$, $6.95(\mathrm{~s}, 1 \mathrm{H}), 6.80(\mathrm{~d}, J=15.81 \mathrm{~Hz}, 1 \mathrm{H}), 3.13(\mathrm{q}, J=6.53 \mathrm{~Hz}, 2 \mathrm{H}), 2.35(\mathrm{~s}, 3 \mathrm{H}), 1.50(\mathrm{sxt}$, $J=7.30 \mathrm{~Hz}, 2 \mathrm{H}), 0.89(\mathrm{t}, J=7.34 \mathrm{~Hz}, 3 \mathrm{H}) ;{ }^{13} \mathrm{C}$ NMR $\left(214 \mathrm{MHz}, \mathrm{DMSO}-d_{6}\right) \delta_{\mathrm{C}} 164.8$, $164.5,146.4,141.8,140.5,139.9,133.9,131.9,130.1,129.7,127.9,123.7,122.8,120.3$, 41.1, 39.8, 39.7, 39.6, 39.5, 39.4, 39.3, 39.2, 22.3, 21.1, 11.5; LC/MS (ESI), RT = 5.8 min, $\mathrm{m} / \mathrm{z} 394(\mathrm{M}+1)$.

\subsubsection{6. (Z)-3-(4-nitrophenyl)-N-propyl-2-[(E)-3-(thien-2-yl)acrylamido]acrylamide} (5112)

This compound was prepared according to the procedure described for the synthesis of 1502 starting from 4-[(Z)-4-nitrobenzylidene]-2-[(E)-2-(thien-3-yl)vinyl]oxazol-5(4H)one $(0.326 \mathrm{~g}, 1 \mathrm{mmol})$ and $n$-propylamine $(0.16 \mathrm{~mL}, 2 \mathrm{mmol})$. The product 5112 was a yellow solid (320 mg, 83\%), Mp 187-188 ${ }^{\circ} \mathrm{C}$. IR ( $\left.\mathrm{KBr}, v_{\max } \mathrm{cm}^{-1}\right) 3272,2964,1650,1609$, 1510, 1335; ${ }^{1} \mathrm{H}$ NMR (600 MHz, DMSO-d $) \delta_{\mathrm{H}} 9.89(\mathrm{~s}, 1 \mathrm{H}), 8.32(\mathrm{t}, J=5.65 \mathrm{~Hz}, 1 \mathrm{H})$, $8.24(\mathrm{~d}, J=9.04 \mathrm{~Hz}, 2 \mathrm{H}), 7.76(\mathrm{~d}, J=9.03 \mathrm{~Hz}, 2 \mathrm{H}), 7.64-7.69(\mathrm{~m}, 2 \mathrm{H}), 7.45(\mathrm{~d}, J=3.39$ $\mathrm{Hz}, 1 \mathrm{H}), 7.15(\mathrm{dd}, J=3.58,5.08 \mathrm{~Hz}, 1 \mathrm{H}), 6.95(\mathrm{~s}, 1 \mathrm{H}), 6.60(\mathrm{~d}, J=15.43 \mathrm{~Hz}, 1 \mathrm{H}), 3.12$ (q, $J=6.40 \mathrm{~Hz}, 2 \mathrm{H}), 1.50(\mathrm{sxt}, J=7.30 \mathrm{~Hz}, 2 \mathrm{H}), 0.89(\mathrm{t}, J=7.53 \mathrm{~Hz}, 3 \mathrm{H}) ;{ }^{13} \mathrm{C} \mathrm{NMR}(214$ MHz, DMSO-d6) $\delta_{\mathrm{C}} 164.7,164.1,146.4,141.7,139.7,133.7,133.6,131.6,130.1,128.7$, 
128.6, 123.7, 123.0, 120.0, 41.1, 39.8, 39.7, 39.6, 39.5, 39.4, 39.3, 39.2, 22.3, 11.5; LC/MS (ESI), RT = $4.9 \mathrm{~min}, \mathrm{~m} / \mathrm{z} 386(\mathrm{M}+1)$.

\subsection{Biological screening}

\subsubsection{Materials for Cell culture}

Different cell lines were originally purchased from American type culture collection (ATCC, Wesel, Germany) and grown in the tissue culture lab of the Egyptian company for production of vaccines, sera and drugs (Vacsera, Giza, Egypt). The cells were transferred to our laboratory and maintained in the appropriate media as following. HCT-116, CACO2, and HT-29 (human colon cancer cell lines) were maintained in Roswell Park Memorial Institute medium (RPMI1640) (Invitrogen, Carlsbad, CA). The mouse skin fibroblasts (C166) and Baby Hamster Kidney fibroblasts (BHK) were grown in Dulbecco Modified Eagle's medium (DMEM). Both media were supplemented with $1 \%$ of $100 \mathrm{mg} / \mathrm{mL}$ of streptomycin, 100 units/ $\mathrm{mL}$ of penicillin and $10 \%$ of heat-inactivated fetal bovine serum (Invitrogen, Carlsbad, CA) in a humidified, 5\% (v/v) CO2 atmosphere at $37^{\circ} \mathrm{C}$.

\subsubsection{Cytotoxicity assay}

The sulforhodamine B (SRB) assays were performed according to Skehan et al. ${ }^{19}$ Briefly, exponentially growing cells were trypsinized, counted and seeded at the appropriate densities (5000 cells/100 $\mu \mathrm{L} /$ well) into 96-well microtiter plates. Cells were incubated in a humidified atmosphere at $37^{\circ} \mathrm{C}$ for $24 \mathrm{~h}$. Then, the cells were exposed to different compounds at the desired concentrations, $(0.01,0.1,1,10$, and $100 \mu \mathrm{M})$ or to $1 \%$ dimethyl sulfoxide (DMSO) for $72 \mathrm{~h}$. At the end of the treatment period, the media were removed, and the cells were fixed with $10 \%$ trichloroacetic acid at $4^{\circ} \mathrm{C}$ for $1 \mathrm{~h}$. Following, the cells 
were washed with tap water four times and incubated with SRB $0.4 \%$ for 30 min. Excess dye was removed by washing repeatedly with $1 \%$ (vol/vol) acetic acid. The protein-bound dye was dissolved in $10 \mathrm{mM}$ Tris base solution for (optical density) OD determination at 510 nm using a SpectraMax plus Microplate Reader (Molecular Devices, CA). Cell viability was expressed relative to the untreated control cells.

\subsubsection{Nuclear fragmentation by DAPI staining}

Cells were cultured on sterile $22 \mathrm{~mm}^{2}$ cover slips (Harvard Apparatus, MA, USA) in sterile six well plates at a density of $2 \times 10^{5}$ cells/well. $24 \mathrm{~h}$ after seeding, cells were exposed to $\mathrm{IC}_{50}$ of the tested compound in fresh medium for $24 \mathrm{~h}$. At the end of the exposure, cells attached to cover slips were washed with PBS and fixed with 3.7\% paraformaldhyde for 10 min, permeabilized with $0.25 \%$ Triton X-100 in TBST containing $0.01 \%$ Tween 20 for $10 \mathrm{~min}$, and blocked for $1 \mathrm{~h}$ with $5 \%$ goat serum in TBST. The fixed and permeabilized cells nuclei were denatured with $2 \mathrm{~N} \mathrm{HCl}(300 \mu \mathrm{l})$ for $10 \mathrm{~min}$, washed three times more, and treated with $0.1 \mu \mathrm{g} / \mathrm{ml}$ 4',6'-Diamidino-2-Phenylindole, dihydrochloride (DAPI) (Sigma-Aldrich, St. Louis, MO, USA) (1:1000) in PBST for $1 \mathrm{~h}$. After staining, the cells were washed twice with PBS. The cover slips were then mounted on a glass slide with antifade mounting medium and viewed with an epifluorescence microscope, Leica, DM 5500 B (Leica, Buffalo Grove, IL, USA) at a magnification of $60 \times$, and data were captured digitally and quantified using the microscope provided software.

\subsubsection{Cell morphology}

Cells were cultured on sterile $22 \mathrm{~mm}^{2}$ cover slips (Harvard Apparatus, MA, USA) in sterile six well plates at a density of $2 \times 10^{5}$ cells/well. $24 \mathrm{~h}$ after seeding, cells were exposed to $\mathrm{IC}_{50}$ of the tested compounds in fresh medium for $24 \mathrm{~h}$. At the end of the exposure, cells 
attached to cover slips were washed with PBS and visulized under leica light microscope (Leica, Buffalo Grove, IL, USA).

\subsubsection{Primary $\left(1^{\circ}\right)$ Colonosphere Formation Assay}

For primary sphere formation, cells were plated in nontreated, low adhesion, 96 wells plate at the concentration of 100 cells $/ 100 \mu \mathrm{L} /$ well in stem cell media (SCM) that consisted of DMEM:F12:AA (Gibco), supplemented with 1×B27 (Gibco), 20 ng/mL epidermal growth factor, and $10 \mathrm{ng} / \mathrm{mL}$ fibroblast growth factor (Sigma). After $4 \mathrm{~h}$ of incubation, vehicle (control) or $\mathbf{3 7 1 2}$ and $\mathbf{4 1 1 2}$ at the desired concentrations were added to each well (at least in triplicates for each sample). On day five, numbers of spheres ranging from 50 to 150 $\mathrm{mm}$ in diameter were counted using phase contrast microscope and percent inhibition was calculated compared to control.

\subsubsection{Determination of ROS accumulation}

To determine the effect of the newly synthesized compounds on the cellular redox status, two different free radical sensitive props, dihydroethidium (DHE) and dichlorofluorescin diacetate (DCFDA) were used. Moreover, the activity of two intracellular antioxidant enzymes, superoxide dismutase (SOD) and catalase (CAT), reduced glutathione (GSH) level and a lipid peroxidation product, Malone di aldehyde (MDA) were assessed. For DHE and DCFDA, cells were cultured on sterile $22 \mathrm{~mm} 2$ cover slips (Harvard Apparatus, MA, USA) in sterile six well plates at a density of $2 \times 105$ cells/well. $24 \mathrm{~h}$ after seeding, cells were exposed to $\mathrm{IC}_{50}$ of the tested compounds in fresh medium for $24 \mathrm{~h}$. At the end of the exposure, cells attached to cover slips were washed thrice with PBS and incubated with DHE $10 \mu \mathrm{M}$ or DCFDA $10 \mu \mathrm{M}$ for $30 \mathrm{~min}$ at $37^{\circ} \mathrm{C}$ in the dark. Thereafter, cells were washed thrice with PBS and the cover slips were then mounted on a glass slide with anti- 
fade mounting medium containing 4',6'-Diamidino-2-Phenylindole, dihydrochloride (DAPI) (Sigma- Aldrich, St. Louis, MO, USA), which was used as counter stain and viewed with an epifluorescence microscope, Leica, DM 5500 B (Leica, Buffalo Grove, IL, USA) at a magnification of $60 \times$. Data were captured digitally and quantified using the microscope provided software.

For assessment of SOD and CAT activities as well as SOD and MDA levels, $4 \times 10^{6}$ cell/ $\mathrm{T} 75$ flask were exposed to the $\mathrm{IC}_{50}$ of tested compound for $24 \mathrm{~h}$. The cells were collected by trypsinization and washed twice with PBS. Cells were directly homogenized in PBS on ice with a Dounce homogenizer 3 times (each 25 strokes) at 10-min intervals, then centrifuged at $15000 \mathrm{rpm}$ for $15 \mathrm{~min}$ at $4{ }^{\circ} \mathrm{C}$. An aliquot was kept to determine the protein concentration using a BioRad protein assay DC kit (Bio Rad Laboratories, CA). Different parameters were then assessed using equal protein amounts in all samples and employing the specified kit according to the manufacturer's instructions. $(3,4,5$ and 6$)$.

\subsubsection{Cell viability assay including pre-treatment with $N$-acetyl cysteine or Trolox}

N-Acetylcysteine (Sigma) was dissolved in sterile water (100 mM). Trolox (Sigma) was dissolved in ethanol $(1 \mathrm{mM})$. Fresh solutions were prepared for each experiment. HCT-116 cells were seeded in 96-well plates at a density of $2.5 \times 10^{4}$ cells $/ \mathrm{mL}$. After $23 \mathrm{~h}$, cells were pre-treated with NAC or Trolox $(2 \mu \mathrm{L})$ for $1 \mathrm{~h}$. The remainder of the assay was carried out as described for the previous cell viability section (7.2.2).

\subsubsection{Apoptotic cell determination}

Apoptosis was determined by staining cells with Annexin V-fluorescein isothiocyanate (FITC) and counterstaining with propidium iodide (PI) using the Annexin V-FITC/PI apoptosis detection kit (BD Biosciences, San Diego, CA, USA) according to the 
manufacturer's instructions. Briefly, $4 \times 10^{6}$ cell/ $\mathrm{T} 75$ flask were exposed to the $\mathrm{IC}_{50}$ of tested compound for 24 and $48 \mathrm{~h}$. The cells were collected by trypsinization and $0.5 \times 10^{6}$ cells were washed twice with phosphate-buffered saline (PBS) and stained with $5 \mu \mathrm{l}$ Annexin V-FITC and $5 \mu \mathrm{l}$ PI in $1 \times$ binding buffer (BD Biosciences, San Jose, CA, USA) for $15 \mathrm{~min}$ at room temperature in the dark. Analyses were performed using FACS Calibur flow cytometer (BD Biosciences, San Jose, CA, USA).

\subsubsection{Determination of acute oral toxicity $\left(\mathrm{LD}_{50}\right)_{[40]}$}

\section{A. Animals and Compounds}

The experiment was conducted on 12 healthy Swiss albino mice (males and females) weighing 22-27 g and aged 8 to 10 weeks obtained from the Animal Station, Pharmacology Dept, Faculty of Pharmacy, King Abdulaziz University, Jeddah. All animals were kept at the regulated temperature (average $23^{\circ} \mathrm{C}$ ), air quality (Central air conditioning) and light (12-h light/dark cycles). Animals were provided free access to food pellets ad libitum and water. The experimental procedure was approved by the Research Ethics Committee, Faculty of Pharmacy, King Abdulaziz University prior to starting the laboratory work. Animals were humanely treated according to international and scientific principles. Changes other than vitality of the animals such as behavioral and food consumption habits were not observed in this study.

The compounds 1512, 3712 and $\mathbf{4 1 1 2}$ of purity 95\% or more (LC/MS) were prepared for this study as $10 \%$ suspension in water containing $0.5 \%$ tween 80 .

\section{B. Acute oral toxicity test}

The animals were distributed randomly into four groups ( 3 mice at each group). One group did not receive any drug (control group). The second group received an oral dose 
of $2000 \mathrm{mg} / \mathrm{Kg}$ of the drug and observed after $24 \mathrm{~h}$ to count the deceased animals.

According to the Guideline 423, when all animals were found alive, the same test was repeated (dose $2000 \mathrm{mg} / \mathrm{Kg}$ ) were give to the third group (3 animals) and observed for 24

h. All animals survived and therefore, a dose of $5000 \mathrm{mg} / \mathrm{Kg}$ were administered to the fourth and final group.

\section{ACKNOWLEDGEMENT}

This project was funded by the Deanship of Scientific Research (DSR), King Abdulaziz University, Jeddah, the Kingdom of Saudi Arabia, under grant number RG-7-166-38.

Authors also would like to thank Professor Alaa Khedr (KAU) and Dr. Mohini Ghatge (VCU) for their valuable help in LC/MS analyses. We also express gratitude to Professor Ashraf Abdel-Naim, Pharmacology and Toxicology Dept, KAU for his guidance on the acute toxicity studies.

\section{PATENTS}

El-Araby, M. E.; Omar, A. M.; Safo, M. K.; Elhaggar, R. S. R.; Abdelghany, T. M. Ahmed, M. Bis-propenamide compounds and methods of treating cancer. US Application 16/663,861, Oct 25, 2019.

\section{REFERENCES}

1. Ahn, B.-Z.; Sok, S.-E. Michael acceptors as a tool for anticancer drug design. Curr. Pharm. Des. 1996, 2, 247-262.

2. Johansson, M. H. Reversible Michael additions: covalent inhibitors and prodrugs. Mini-Rev. Med. Chem. 2012, 12, 1330-1344.

3. Kafarski, P.; Talma, M. Recent advances in design of new urease inhibitors: A review. J. Adv. Res. 2018, 13, 101-112.

4. Minkovsky, N.; Berezov, A. BIBW-2992, a dual receptor tyrosine kinase inhibitor for the treatment of solid tumors. Curr. Opin. Investig. Drugs 2008, 9, 1336-46.

5. Suzawa, K.; Toyooka, S.; Sakaguchi, M.; Morita, M.; Yamamoto, H.; Tomida, S.; Ohtsuka, T.; Watanabe, M.; Hashida, S.; Maki, Y.; Soh, J.; Asano, H.; Tsukuda, 
K.; Miyoshi, S. Antitumor effect of afatinib, as a HER2-targeted therapy, in lung cancers harboring HER2 oncogene alterations. Cancer Sci. 2015.

6. Zhang, Q.; Lu, B.; Li, J. Design, synthesis and biological evaluation of 4piperazinyl-containing Chidamide derivatives as HDACs inhibitors. Bioorg. Med. Chem. Lett. 2017, 27, 3162-3166.

7. Singh, J.; Petter, R. C.; Baillie, T. A.; Whitty, A. The resurgence of covalent drugs. Nat. Rev. Drug Discov. 2011, 10, 307-17.

8. Lanning, B. R.; Whitby, L. R.; Dix, M. M.; Douhan, J.; Gilbert, A. M.; Hett, E. C.; Johnson, T. O.; Joslyn, C.; Kath, J. C.; Niessen, S.; Roberts, L. R.; Schnute, M. E.; Wang, C.; Hulce, J. J.; Wei, B.; Whiteley, L. O.; Hayward, M. M.; Cravatt, B. F. A road map to evaluate the proteome-wide selectivity of covalent kinase inhibitors. Nat. Chem. Biol. 2014, 10, 760-7.

9. Wondrak, G. T. Redox-directed cancer therapeutics: molecular mechanisms and opportunities. Antioxid. Redox Signal. 2009, 11, 3013-69.

10. Stevens, J. F.; Maier, C. S. Acrolein: sources, metabolism, and biomolecular interactions relevant to human health and disease. Mol. Nut Food Res. 2008, 52 , 7-25.

11. Chan, K.; Poon, R.; O'Brien, P. J. Application of structure-activity relationships to investigate the molecular mechanisms of hepatocyte toxicity and electrophilic reactivity of alpha,beta-unsaturated aldehydes. J. Appl. Toxicol. 2008, 28, $1027-$ 39.

12. Schwobel, J. A.; Wondrousch, D.; Koleva, Y. K.; Madden, J. C.; Cronin, M. T.; Schuurmann, G. Prediction of michael-type acceptor reactivity toward glutathione. Chem. Res. Toxicol. 2010, 23, 1576-85.

13. Luis, P. B.; Boeglin, W. E.; Schneider, C. Thiol Reactivity of Curcumin and Its Oxidation Products. Chem. Res. Toxicol. 2018, 31, 269-276.

14. Autelitano, A.; Minassi, A.; Pagani, A.; Taglialatela-Scafati, O.; Appendino, G. The reaction of cinnamaldehyde and cinnam (o) yl derivatives with thiols. Acta Pharm. Sin. B. 2017, 7, 523-526.

15. Lin, L. T.; Tai, C. J.; Chang, S. P.; Chen, J. L.; Wu, S. J.; Lin, C. C.

Cinnamaldehyde-induced apoptosis in human hepatoma PLC/PRF/5 cells involves the mitochondrial death pathway and is sensitive to inhibition by cyclosporin A and z-VAD-fmk. Anticancer Agents Med. Chem. 2013, 13, 1565 74.

16. Wondrak, G. T.; Villeneuve, N. F.; Lamore, S. D.; Bause, A. S.; Jiang, T.; Zhang, D. D. The cinnamon-derived dietary factor cinnamic aldehyde activates the Nrf2dependent antioxidant response in human epithelial colon cells. Molecules 2010, $15,3338-55$.

17. Kwon, H. K.; Hwang, J. S.; So, J. S.; Lee, C. G.; Sahoo, A.; Ryu, J. H.; Jeon, W. K.; Ko, B. S.; Im, C. R.; Lee, S. H.; Park, Z. Y.; Im, S. H. Cinnamon extract induces tumor cell death through inhibition of NFkappaB and AP1. BMC Cancer 2010, 10, 392.

18. Cabello, C. M.; Bair, W. B., 3rd; Lamore, S. D.; Ley, S.; Bause, A. S.; Azimian, S.; Wondrak, G. T. The cinnamon-derived Michael acceptor cinnamic aldehyde impairs melanoma cell proliferation, invasiveness, and tumor growth. Free Radic. Biol. Med. 2009, 46, 220-31. 
19. Ka, H.; Park, H. J.; Jung, H. J.; Choi, J. W.; Cho, K. S.; Ha, J.; Lee, K. T.

Cinnamaldehyde induces apoptosis by ROS-mediated mitochondrial permeability transition in human promyelocytic leukemia HL-60 cells. Cancer Lett. 2003, 196, 143-52.

20. Aggarwal, B. B.; Surh, Y.-J.; Shishodia, S., The molecular targets and therapeutic uses of curcumin in health and disease. Springer Science \& Business Media: 2007; Vol. 595.

21. El-Araby, M. E.; Omar, A. M.; Khayat, M. T.; Assiri, H. A.; Al-Abd, A. M. Molecular Mimics of Classic P-Glycoprotein Inhibitors as Multidrug Resistance Suppressors and Their Synergistic Effect on Paclitaxel. PLoS One 2017, 12, e0168938.

22. Omar, A. M.; Abdelghany, T. M.; Abdel-Bakky, M. S.; Alahdal, A. M.; Radwan, M. F.; El-Araby, M. E. Design, Synthesis and Antiproliferative Activities of Oxidative Stress Inducers Based on 2-styryl-3,5-dihydro-4[5H]-imidazol-4-one Scaffold. Chem. Pharm. Bull. 2018, advpub.

23. Siegel, R. L.; Miller, K. D.; Jemal, A. Cancer statistics, 2016. CA Cancer J. Clin. 2016, 66, 7-30.

24. Al-Zalabani, A. Preventability of Colorectal Cancer in Saudi Arabia: Fraction of Cases Attributable to Modifiable Risk Factors in 2015-2040. Int. J. Environ. Res. Public Health 2020, 17.

25. Thanikachalam, K.; Khan, G. Colorectal cancer and nutrition. Nutrients 2019, 11, 164.

26. Van der Jeught, K.; Xu, H.-C.; Li, Y.-J.; Lu, X.-B.; Ji, G. Drug resistance and new therapies in colorectal cancer. World J. Gastroenterol. 2018, 24, 3834-3848.

27. Zhang, P.; Hu, H.-R.; Bian, S.-H.; Huang, Z.-H.; Chu, Y.; Ye, D.-Y. Design, synthesis and biological evaluation of benzothiazepinones (BTZs) as novel non-

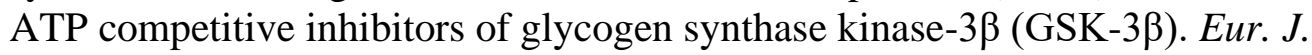
Med. Chem. 2013, 61, 95-103.

28. El-Araby, M.; Omar, A.; Hassanein, H. H.; El-Helby, A. G.; Abdel-Rahman, A. A. Design, synthesis and in vivo anti-inflammatory activities of 2,4-diaryl-5-4Himidazolone derivatives. Molecules 2012, 17, 12262-75.

29. Skehan, P.; Storeng, R.; Scudiero, D.; Monks, A.; McMahon, J.; Vistica, D.; Warren, J. T.; Bokesch, H.; Kenney, S.; Boyd, M. R. New colorimetric cytotoxicity assay for anticancer-drug screening. J. Natl. Cancer Inst. 1990, 82, 1107-12.

30. Drutovic, D.; Chripkova, M.; Pilatova, M.; Kruzliak, P.; Perjesi, P.; Sarissky, M.; Lupi, M.; Damia, G.; Broggini, M.; Mojzis, J. Benzylidenetetralones, cyclic chalcone analogues, induce cell cycle arrest and apoptosis in HCT116 colorectal cancer cells. Tumour Biol. 2014, 35, 9967-75.

31. Patel, N. J.; Karuturi, R.; Al-Horani, R. A.; Baranwal, S.; Patel, J.; Desai, U. R.; Patel, B. B. Synthetic, non-saccharide, glycosaminoglycan mimetics selectively target colon cancer stem cells. ACS Chem. Biol. 2014, 9, 1826-33.

32. Spielmann, H.; Genschow, E.; Liebsch, M.; Halle, W. Determination of the starting dose for acute oral toxicity (LD50) testing in the up and down procedure (UDP) from cytotoxicity data. ATLA 1999, 27, 957-966. 
33. Shi, X.; Zhang, Y.; Zheng, J.; Pan, J. Reactive Oxygen Species in Cancer Stem Cells. Antioxid. Redox Signal. 2012, 16, 1215-1228.

34. Ding, S.; Li, C.; Cheng, N.; Cui, X.; Xu, X.; Zhou, G. Redox Regulation in Cancer Stem Cells. Oxid. Med. Cell. Longev. 2015, $2015,750798$.

35. Fahmy, A.; Orabi, M. Reactions of 4-arylidene-2-styryl-5 (4)-oxazolones and related compounds. Indian J. Chem. 1972, 10, 961-964.

36. Kumar, P.; Mishra, H. D.; Mukerjee, A. K. Condensation of 2-substituted 5-oxo4, 5-dihydro-1, 3-oxazoles with imines and their corresponding carbonyl compounds. Synthesis 1980, 1980, 836-839.

37. Mustafa, A.; Asker, W.; Harhash, A. H.; Abdin, T. M. S.; Zayed, E. M. Reaktionen mit 2.4-disubstituierten $\Delta 2$-Oxazolinonen-(5). Justus Liebigs Annalen der Chemie 1968, 714, 146-154.

38. Mustafa, A.; Asker, W.; Harhash, A. H.; Abdin, T.; Zayed, E. M. Reaktionen mit 2.4-disubstituierten $\Delta 2-$ Oxazolinonen-(5). Justus Liebigs Ann. Chem. 1968, 714, 146-154.

39. Tripathy, P. K.; Mukerjee, A. K. A facile synthesis of N-substituted 2-acylamino2-alkenamides. Synthesis 1985, 1985, 285-288.

40. Shoieb, S. M.; Esmat, A.; Khalifa, A. E.; Abdel-Naim, A. B. Chrysin attenuates testosterone-induced benign prostate hyperplasia in rats. Food Chem. Toxicol. 2018, 111, 650-659. 